\title{
Creativity, Community, and Memory Building: Interned Jewish Refugees in Canada During and After World War II
}

\author{
By \\ Elise Bigley \\ A thesis submitted to the Faculty of Graduate and Postdoctoral Affairs in partial \\ fulfillment of the requirements for the degree of \\ Master of Arts \\ in \\ History with Specialization in Digital Humanities \\ Carleton University \\ Ottawa, Ontario \\ (C)2017 \\ Elise Bigley
}




\begin{abstract}
In May of 1940, a wartime British government arrested those deemed "enemy aliens" and transferred them to safe areas of the country. Over 2000 of these "enemy aliens" were Jewish German and Austrian men. On June 29, 1940, the first group of Jewish refugees was sent to internment camps in Canada. This thesis explores three different examples of memory and community to illustrate the development of the internees' search for meaning during and post-internment. Artwork created in the camps, a series of letters between ex-internees, and several issues of the Ex-Internees Newsletter are the focus of this study. Social network analysis tools are used to visualize the postinternment internee network. By looking at diverse aspects of the internment narrative, this thesis provides a unique lens into the conversation on memory and history.
\end{abstract}




\section{Acknowledgments}

I would like to express my deep gratitude to my co-supervisors Dr. John C. Walsh and Dr. James Opp for their useful comments, remarks, and engagement during the past two years. A special thanks to John for accepting all of my work past the many 'deadlines' I set for myself.

This thesis would not have been possible without the expertise of Dr. Shawn Graham. Thank you for opening my eyes to the digital humanities, the value of failure, and how approaching history with a touch of 'the digital' allows for a whole new world of questions to be asked.

I am grateful to the staff at the Ottawa Jewish Archives and Library and Archives Canada for their help with my research. I would like to thank the department of History and my fellow grad students and friends for providing support, friendship, and camaraderie found at Mike's Place.

I would like to thank my family and friends who spent countless hours analyzing paintings, network graphs you did not understand, and learning about something you never thought you would. A special thanks to David Bakker for bearing the brunt of this, and for smiling along even when you had no idea what I was talking about. I would also like to thank my good friend Sam Biagioni for reading almost every paper I have written since beginning my undergraduate career.

To Dr. Elise Chenier, Dr. Willeen Keough, and Dr. Jeremy Brown of Simon Fraser University: thank you for your mentorship during my undergraduate degree and your help in applying to graduate school. 
Finally, I am indebted to Nina Krieger, Lise Kirchner, and Elizabeth Shaffer of the Vancouver Holocaust Education Centre for their support and encouragement over the past two years. I am grateful to them for instilling in me the importance of Holocaust education and a passion for using historical research as a tool for countering racism. 
Table of Contents

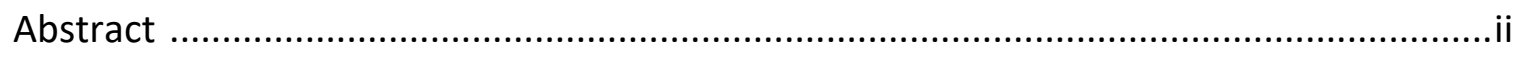

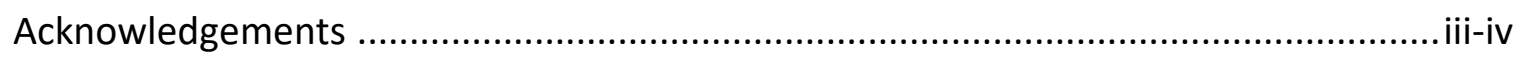

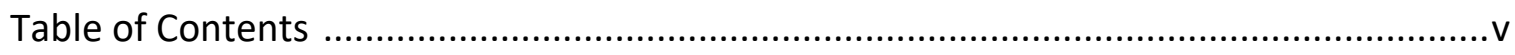

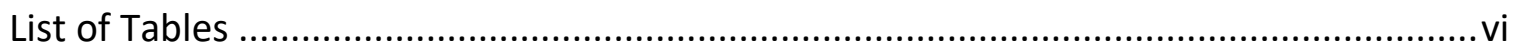

List of Illustrations ...............................................................................................

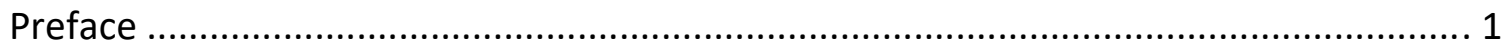

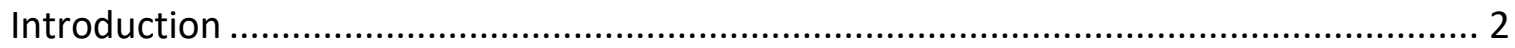

Chapter One: Creativity, Community Building, and Protest ...................................... 12

Chapter Two: The Community Plot: Mapping Social Networks .................................. 43

Chapter Three: Community Without Locality in Post-Internment Networks ................. 72

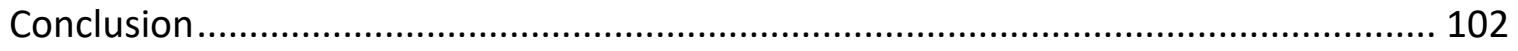

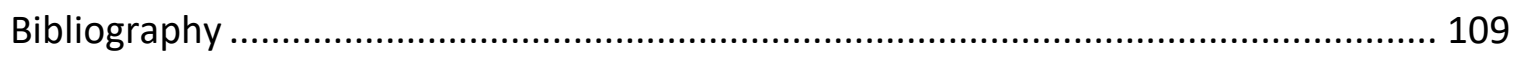




\section{List of Tables}

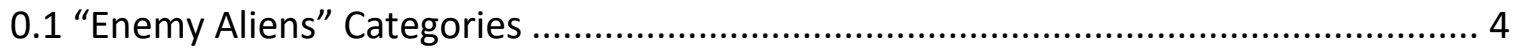

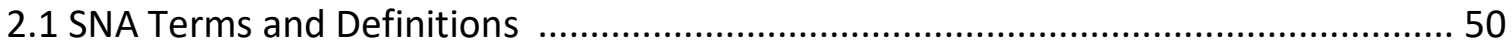

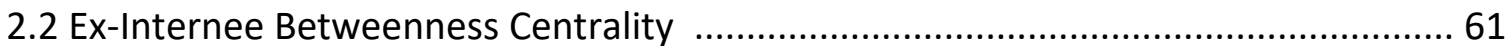




\section{List of Illustrations}

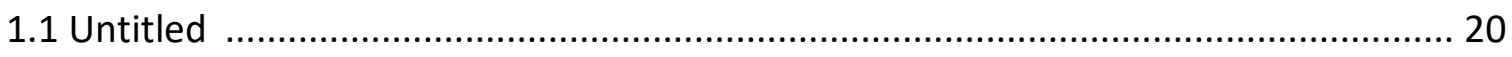

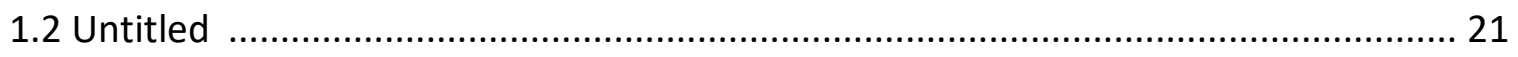

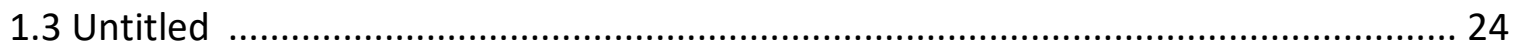

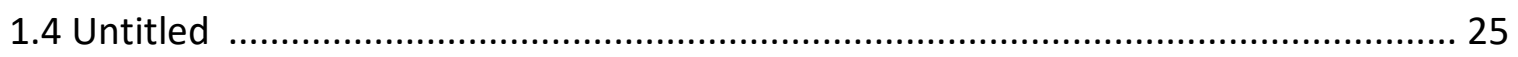

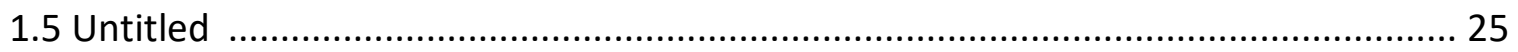

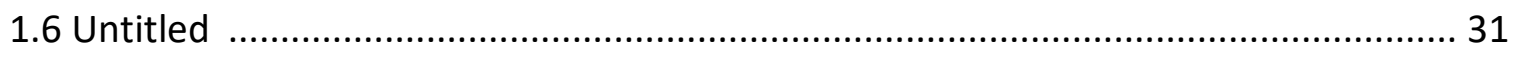

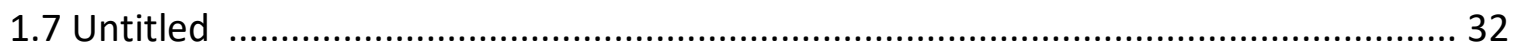

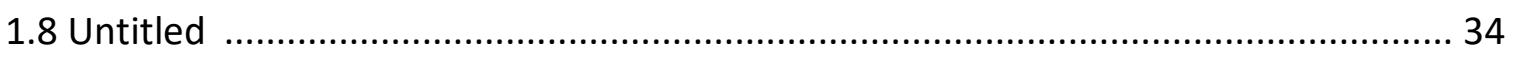

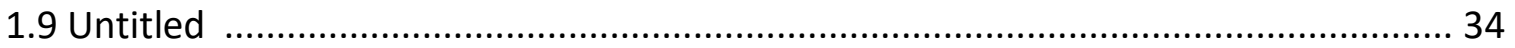

2.1 Initial Graph Based on Correspondence with Koch ............................................ 52

2.2 Graph with Outliers Based on Correspondence with Koch ................................... 54

2.3 Graph with no Outliers Based on Correspondence with Koch ............................... 56

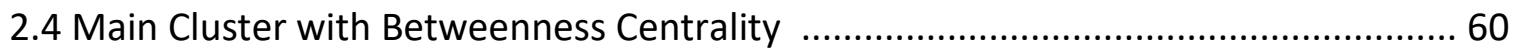

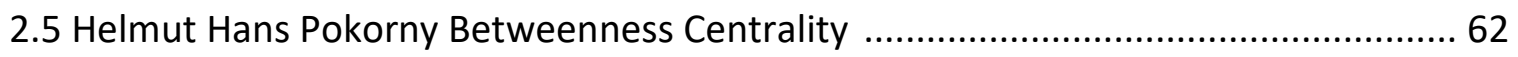

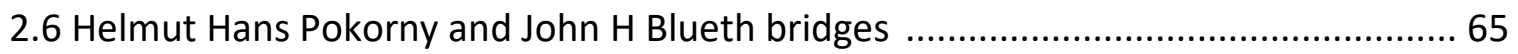

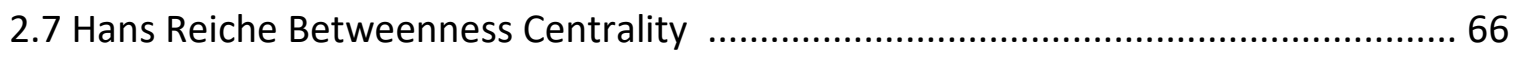

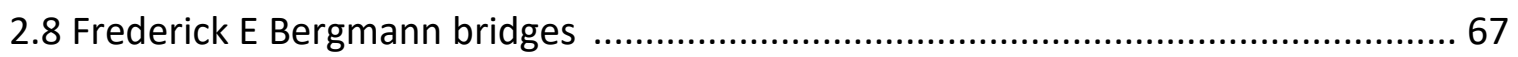

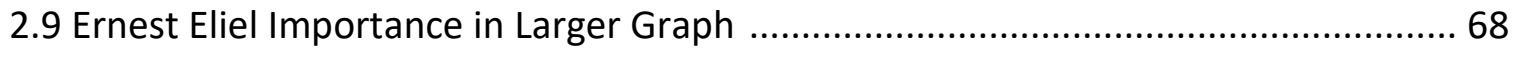

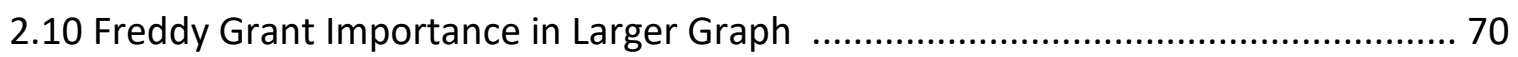

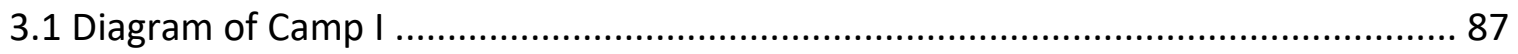

3.2 Camp Q - Drawings by Henry H. Chary 1940..................................................... 88

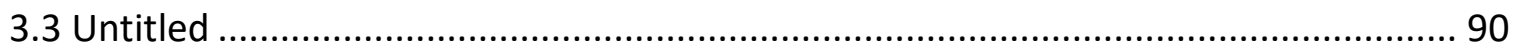




\section{Preface}

One day the order comes

to go

to an unknown

destination.

We had to go, we could

not know

of our deportation.

Heavy seas, wind and

fog,

flying boats and

battleships

past Irish Green and

Scottish Rock

convoy us along the trip;

forward, zig zag, up and

down

not knowing where we

go

water grey, green, blue

around,

waving high and low.

Machine gun nests in towers

straw and dust as bed

it will not be flowers

neither blue nor white

nor red.

Canadian Arena for cattle

with many rows of seats

dust, dirt, heat fight

battle

until sleep succeeds.

A thousand beds it seems

the room can hold

in our dreams

we feel alone and cold.

Across the stream

through endless plains

of woods we steam in a Wild Western train.

We wake and sleep in

noise and heat

until we meet

ourselves again, amidst

the air

of Pine and Birch Tree,

green, fresh, fair.

We land behind the wire

where once were trees.

Land was laid waster

we're chased

in huts

unfinished - grey

to live there chaste

as best we may.

With ups and downs

timeless we call it life

an evening greets, a

morning frowns

in circles turns the hive.

Outside the world exists

we are locked in, cut off

shrouded in mists

of unknown

whereabouts

struck off the list

living in clouds.

Force used against us

but we too have force

and clear a path

to those who understand

and not forget us.

We do not cease

to ask for right

till our force

brings light.

We are always together wherever we are wherever we gather

we are what we are.

That gives us courage

and clarity

force hope and unity.

You are one of us

we are everywhere

where the world goes

round

everywhere

whether free or bound.

You are with us

and we with you.

We are today and

tomorrow too

all of us - we and you.

Internment Camp B

Canada

December 1940

(Author unknown) $^{1}$
${ }^{1}$ This is an excerpt from a poem sent in a letter by exinternee Werner Buchholz to Eric Koch. Werner Buchholz to Eric Koch, March 29, 1980, Correspondence between Eric Koch and other internees while he collected material for his book on the internment experience 19791980: A-F, Eric Koch fonds, Library and Archives Canada (LAC), MG 30 C-192, Vol. 1. 


\section{Introduction}

As I sit in the reading room of Library and Archives Canada, reviewing this poem documenting the journey of over 2,000 Jewish refugees who found themselves behind Canadian barbed wire during the Second World War, I reflect on how I came across this fascinating piece of Canadian history. On February 7, 2014 the National Post published an article on the internment of Austrian and German Jewish refugees in Eastern Canada during the Second World War. Several surviving refugees were interviewed about their experiences in the camps. The article contained photographs of the internees during their internment, and photographs of them in 2014. It also referenced the exhibition Enemy Aliens: The Internment of Jewish Refugees in Canada, 1940-1943 developed by the Vancouver Holocaust Education Centre in $2012 .{ }^{1}$ The online exhibition features several paintings created by Jewish refugees while in the camps. ${ }^{2}$ Inspired by both the Post's article and the Centre's exhibition, I decided to visit the archival source of this turbulent past that makes up a piece of the fabric of Canadian history.

The fonds of ex-internee Eric Koch (Camp N, Sherbrooke, Quebec) are found at Library and Archives Canada (LAC), which houses numerous documents pertaining to internment life. Among these records are a series of paintings within a scrapbook compiled by Koch, a monument of sort that strives to both remember and document his

\footnotetext{
${ }^{1}$ Graeme Hamilton, "How Jewish 'enemy aliens' overcame a 'traumatic' stint in Canadian prison camps during the Second World War," National Post, February 7, 2014.

${ }^{2}$ VHEC exhibit “'Enemy Aliens': The Internment of Jewish Refugees in Canada, 1940-43," http://www.enemyaliens.ca/.
} 
and others' time in the internment camps. ${ }^{3}$ The scrapbook's many contributors are all Jewish refugees. Reading it, I came to appreciate that it is an effort to make sense of internment and to process the unique experience of being both exiled and imprisoned for the simple fact of their ethno-religious identity. The scrapbook and the poem, which opened this thesis are examples of artistic expression produced by Jewish refugees during internment life. This thesis examines this art as both creative expression and as a method of community building by refugees, not rooted in one geographical space (i.e. camp) and stretching over many decades of time during and after the internment experience.

My viewing of the paintings in the scrapbook, which is the focus of Chapter One, is both enriched and complicated by the context in which I encountered them in the archives. In Eric Koch's fonds are letters between Koch and his family in the 1930s and 1940s, as well as a series of letters between him and fellow Jewish refugees as he gathered information in the years leading up to the publication of his autobiography, Deemed Suspect: A Wartime Blunder, in 1980. I view the paintings as the foundation of a process that documented their experiences. These letters illuminate the willingness and desire of many internees to remain in contact with each other, and enhance my understanding of the importance of community for the internees both during and after internment. A deeper analysis of the significance of these letters forms the bulk of Chapter Two. Another example of the results of this desire for community is the development of the Ex-Internees Newsletter in the 1990s, which will be the central focus

\footnotetext{
${ }^{3}$ Behind Barbed Wire Scrapbook, Eric Koch fonds, Library and Archives Canada (LAC), MG 30 C-192, Vol. 1.
} 
of Chapter Three. Recognizing the enthusiasm from the internees to contribute to a published history of their internment is an important aspect to consider while exploring the artwork created during their internment experience in Canada.

\section{A History of Internment}

In June 1940, over 2,000 male Jewish refugees, between the ages of 16 and 60, of German and Austrian citizenship, were interned in Canada during the Second World War. The history of their internment began early in the war, when the British government held tribunals to determine the fate of Germans and Austrians, both Jewish and non-Jewish, who then resided in England. They were classified into three categories:

Table 0.1 "Enemy Alien" Categories

\begin{tabular}{|l|l|}
\hline Category: & Ruling: \\
\hline Category A & $\begin{array}{l}\text { Those suspected of Nazi sympathies. Immediate } \\
\text { internment. }\end{array}$ \\
\hline Category B & Exempt from internment. Restricted freedom. \\
\hline Category C & $\begin{array}{l}\text { Genuine refugees from Nazi oppression. Exempt } \\
\text { from internment. }^{4}\end{array}$ \\
\hline
\end{tabular}

Category C designated 'friendly' enemy aliens, and the designation of this status was often very arbitrary. ${ }^{5}$ In May 1940, as the war carried on and Winston Churchill was elected Prime Minister of England, plans were made to override Category $C$ and instead intern these 'friendly' enemy aliens from age 16 to 60 in British and subsequent Canadian camps. ${ }^{6}$ These interned refugees from Nazi oppression were viewed not as

\footnotetext{
${ }^{4}$ Yvonne M. Cresswell, Living with the Wire: Civilian Internment in the Isle of Man During Two Cold Wars (United Kingdom: Manx National Heritage, 1994), 61.

${ }^{5}$ Cresswell, Living with the Wire, 62.

${ }^{6}$ Eric Koch, Deemed Suspect: A Wartime Blunder (Toronto: Metheun, 1980), 14.
} 
individuals, but as a conglomerate of Germans and Austrians. Their connection to Nazi

Germany remained an object of fear for Britain. The psychological effects of this

grouping continued into the internment period on Canadian soil. The internees were

continuously mislabeled and, as a consequence, were often mistreated. They were

involuntarily interned and put in the same category of others under paternal

stewardship.

Once on Canadian soil, Category C internees were treated no differently than the

Category A Nazi prisoners of war. Erwin Schild, a Jewish internee in Canada during the

Second World War, recalls:

It became obvious, as our guards escorted us from the ship, that the authorities in charge of our reception were not expecting Jewish refugees from Nazi Germany, but Nazi soldiers and German civilians - in other words, enemies. While the British guards on board our ship had carefully kept the German and Italian prisoners of war separate from the refugees to avoid any untoward incidents, the Canadian military was not aware of any such distinctions, except for the difference between military prisoners and civilians ... As far as the Canadian military was concerned, all of us were dangerous enemies whom Canada had undertaken to guard. For that reason, much to our dismay and surprise, security was tight and frightening. ${ }^{7}$

As Schild recounts, neither the Canadian military nor the Canadian government knew that genuine refugees from Nazi oppression were aboard the ships. A telegram on June 19, 1940 from the High Commissioner for Canada in Great Britain noted that on the first two vessels, only Category A and Category B German and Italian internees were aboard. There was no mention of Category C internees, the 'friendly' enemy aliens. Nearly a

\footnotetext{
${ }^{7}$ Erwin Schild, The Very Narrow Bridge: A Memoir of an Uncertain Passage (Canada: Adath Israel Congregation and Malcolm Lester, 2001), 216.
} 
month later, on July 16,1940 , a telegram from the High Commissioner to the Secretary of State for External Affairs admitted, "it appears that a number of individuals were sent to Canada by mistake" and that if it were true it would be very difficult to treat these internees under the same request Britain provided for Category $A$ internees. ${ }^{8}$ The situation remained an issue for the Canadian and British governments well into the fall of 1940. N. A. Robertson of the Department of External Affairs sent a memorandum to the Prime Minister on October 21 stating that "a good deal of progress [had] been made in segregating the $B$ and $C$ category civilian internees from the dangerous Nazis of $A$ Category with whom they were at first lumped indiscriminately." ${ }^{9}$ Robertson recognized the psychological difficulties that arose from the placement of Nazis and Jewish refugees in the same camp, pointing out this arrangement, "undoubtedly caused a great deal of understandable heart burning among the unfortunate refugees from Nazi oppression who have been brigaded with the Nazis themselves." ${ }^{10}$ It was not until the British acknowledged that most of the civilian internees from Britain were refugees that Canada issued Order-in-Council PC 4568 on June 25, 1941, which gave the interned Jews refugee status. ${ }^{11}$

Jewish refugees were placed in various internment camps throughout Ontario, Quebec, and New Brunswick. Life behind barbed wire for the Jewish internees varied

\footnotetext{
${ }^{8}$ Henry Friedlander, and Sybil Milton, eds., Archives of the Holocaust: An International Collection of Selected Documents, Volume 15 (New York and London: Garland, 1990), 179.

${ }^{9}$ Friedlander and Milton, eds., Archives of the Holocaust, 186.

${ }^{10}$ Friedlander and Milton, eds., Archives of the Holocaust, 187.

${ }^{11}$ Martin F. Auger, Prisoners of the Home Front: German POWs and "Enemy Aliens" in Southern Quebec, 1940-46 (Vancouver: UBC Press, 2009), 30-31.
} 
tremendously from camp to camp. ${ }^{12}$ Camp B in New Brunswick had a military style barrack established when internee Erwin Schild arrived. He described it as living, "with the comforts and discomforts similar to those experienced by recruits in the army. ${ }^{13}$ Walter Igersheimer described Camp N in Sherbrooke, Quebec, the same camp where Eric Koch spent the war, as a dreary abandoned shed, with broken windows, damaged roof, and mud covering the ground. ${ }^{14}$ Boards, benches, and stones were arranged so that the internees could attempt to sit in the shed and remain dry. ${ }^{15}$ The camp consisted of two abandoned railway machine shops. ${ }^{16}$ The physical particulars of each camp fostered the unique development and quality of camp life and activities. Some internees lived in these camps some for 6 months, while others were not released until 1942.

Once settled in the camp, Jewish internees had the "freedom" to pass their days with activities of their choosing and avoid the monotony of daily routine. They often made use of the facilities available for entertainment and recreation. ${ }^{17}$ Individual internees shaped these practices. The internee population consisted of chefs, musicians, authors, doctors, students, professional artists, and academics among others. If motivated, they each added a distinct angle to the creative activities. Educational and religious opportunities were created in the camps. In some cases, Yeshivah students

\footnotetext{
${ }^{12}$ The scope of this chapter (and thesis) is not limited to one or two camps, but focuses on paintings created by internees in Camp $\mathrm{N}$.

${ }^{13}$ Schild, The Very Narrow Bridge, 222-223.

${ }^{14}$ Walter W. Igersheimer, Blatant Injustice: The Story of a Jewish Refugee from Nazi Germany Imprisoned in Britain and Canada during World War II (Montreal \& Kingston: McGill-Queen's University Press, 2005), 107.

${ }^{15}$ Igersheimer, Blatant Injustice, 111.

${ }^{16}$ Igersheimer, Blatant Injustice, 220.

${ }^{17}$ Schild, The Very Narrow Bridge, 222-223.
} 
provided the possibility for others to study. ${ }^{18}$ Cooking and baking nurtured a space for chefs and bakers within the camp. ${ }^{19}$ Musical performances were a key aspect of this period, with renowned musicians who had studied in Vienna and Berlin performing for their fellow internees. ${ }^{20}$ Art was also a prevalent occupation, with the creation of cartoons, drawings, and paintings. These diversions were all creative methods that motivated internees sought out in an attempt to enhance their internment experience, and perhaps in their own way "escape" the fact of their bodily confinement.

Camp life constituted an all-male prison-like environment. The most detrimental aspect of the camps was the clear lack of freedom. Erwin Schild recounts: "our suffering was psychological: firstly, the painful, undeserved deprivation of freedom, and secondly, the mental anguish a Jew must feel to be locked up as a German and a suspected Nazi sympathizer."21 A. L. Vischer coined the term "barbed wire psychosis" or "barbedwireitis" in 1919 to describe the psychological condition that plagues prisoners of war and civilian internees. ${ }^{22}$ Some of the symptoms include difficulty concentrating, restlessness, suspicion, depression, and feelings of intense hatred. ${ }^{23}$ Historian Jonathan Vance outlines some of the factors that produce this state of mind:

The first is simply the loss of freedom, the prisoners' inability to do as they please, when they please ... monotony, the realization that every day was the same as the last, is also a factor. This lack of variety is complicated by the fact that it is indefinite...the POW has no way of knowing if his captivity will

\footnotetext{
${ }^{18}$ Ted Jones, Both Sides of the Wire (New Brunswick: New Ireland Press, 1989), 74-75.

${ }^{19}$ Schild, The Very Narrow Bridge, 226.

${ }^{20}$ Auger, Prisoners of the Home Front, 49-50.

${ }^{21}$ Schild, The Very Narrow Bridge, 222.

${ }^{22}$ Auger, Prisoners of the Home Front, 52. See also A. L. Vischer, Barbed Wire Disease: A Psychological Study of the Prisoners of War (London: John Bale, Sons, and Danielsson, 1919).

${ }^{23}$ Auger, Prisoners of the Home Front, 52.
} 
last weeks or months or years; there is no release date to look forward to, and this accentuates the prisoners' feeling of helplessness. The lack of privacy is also important. In the cramped confines of a prison camp, it is virtually impossible to get a moment to oneself ... finally, Vischer identified sexual deprivation as a factor in barbed-wire disease. ${ }^{24}$

These factors all played a significant role in the development of the camp environment and the internee's mindset in Canada during the Second World War.

\section{Literature Review}

This thesis situates itself within a rich historiography of Canadian internment. ${ }^{25}$ Martin F. Auger explores German POWs and Enemy Aliens in Southern Quebec. ${ }^{26}$ Paula Jean Draper and Robert Zimmerman give detailed accounts of the history of Jewish internment in Canada. ${ }^{27}$ Christine Whitehouse has recently added to this body of scholarship with her PhD dissertation on the internment of Jewish refugees. ${ }^{28}$ My thesis breaks from this traditional stream of literature by not only listening to the voices of the internees and their desire to have their history remembered, but also making more

\footnotetext{
${ }^{24}$ Auger, Prisoners of the Home Front, 52-53. See also Jonathan F. Vance, Encyclopedia of Prisoners of War and Internment (Santa Barbara: ABC-CLIO, 2000).

${ }^{25}$ Martin F. Auger, Prisoners of the Home Front (Vancouver: UBC Press, 2009); Patrick Farges, "Masculinity and Confinement: German-Speaking Refugees in Canadian Internment Camps (1940-1943)," Culture, Society \& Masculinities 4, no. 1 (2012); Paula Jean Draper, "The Accidental Immigrants: Canada and the Interned Refugees, Part I," Canadian Jewish Historical Society Journal 2, no. 1(Spring 1978): 1-38; Paula Jean Draper, "The Accidental Immigrants: Canada and the Interned Refugees, Part II," Canadian Jewish Historical Society Journal 2, no. 2 (Fall 1978): 80-112; Paula Jean Draper, "The Accidental Immigrants: Canada and the Interned Refugees" (PhD diss., University of Toronto, 1983); Franca lacovetta, Angelo Principe, and Roberto Perin, eds., Enemies within: Italian and other internees in Canada and abroad (Toronto: University of Toronto Press, 2000); Ted Jones, Both Sides of the Wire, Vols. 1 \& 2 (New Brunswick: New Ireland Press, 1989); Kirsten McAllister, “Photographs of a Japanese Canadian internment camp, Visual Studies 21, no. 2 (October 2006): 133-156; Pamela Sugiman, “Passing Time, Moving Memories," Social History 37, no. 73 (2004): 51-79; Christine Whitehouse, "You'll Get Used to It!': The Internment of Jewish Refugees in Canada 1940-1943" (PhD diss., Carleton University, 2016); Ernest Robert Zimmerman, The Little Third Reich on Lake Superior, eds. Michel S. Beaulieu and David K. Ratz (Alberta: The University of Alberta Press, 2015).

${ }^{26}$ Auger, Prisoners of the Home Front.

27 Draper, "The Accidental Immigrants."; Zimmerman, The Little Third Reich on Lake Superior.

${ }^{28}$ Whitehouse, "'You'll Get Used to It!'."
} 
clear the community of internees that formed and reformed after internment. By doing so, this thesis argues, we gain an additional lens into the concept of community and the ways in which discourse surrounding identity and remembering a complicated history that is not geographically rooted. In the chapters that follow, this literature is addressed more fully to distill where this thesis overlaps and diverges from the findings of others. Chapter One looks to the ways community manifested within the internment camps. Various educational, arts, and sports initiatives were development in the camps that fostered a sense of community. This chapter looks to artwork as one result of building and as a method of expression of resistance and protest. These paintings illustrate specific aspects of camp life and exemplify some of the shared frustrations and desires felt amongst internees during their experience in confinement. Additionally, it explores the ways in which masculinity and gender were expressed and communicated through this method of creative expression.

Chapter Two looks to social network theory to analyze the post-internment community. I extracted data from letters of hundreds of ex-internees to Eric Koch in response to his quest for information about internment for his memoir Deemed Suspect. In these letters, ex-internees listed their "post-internment networks" that they kept since their release. Data was taken from each response in the letters and by using the digital program Gephi the data was mapped onto a visualization to illustrate the larger internee network. This digital tool allows us to visualize and recognize a strong network that would not have been apparent by simply looking through the archives themselves. It allows for different questions to be asked about the network, two of which are central 
to this chapter: what beyond the barbed wire formed and maintained these communities? Were these communities ones of convenience or shared interests?

Chapter Three looks to one of the results of ex-internees creating a space for discourse on their history: the Ex-Internees Newsletter, compiled by ex-internee Helmut Kallmann. From 1996 to 2000, Kallmann distributed the newsletter to ex-internees sharing news and achievements pertaining to the ex-internees. This newsletter in its search for meaning of their history of internment functioned, it is argued, as a lieu de memoire (a site of memory) as theorized by Pierre Nora, where the internees grappled with their understanding their collective legacy and identity. By searching for a way to memorialize and have their experiences remembered, these ex-internees were constructing a space for memorialization.

This thesis contributes to our understanding of memory of places that no longer exist and the ongoing conversation about identity and community within the framework of this complicated history. It will look at specific aspects of internment and provide new perspectives to approach the history of Jewish internment in Canada. By looking at specific and different aspects of internment and memory making, this thesis exemplifies the various ways in which those who experienced history can interact with it. The analysis of an all male group also will explore the ways in which this memory can be gendered and how it impacts what is remembered and highlighted. 


\section{Chapter One: Creativity, Community Building, and Protest}

This chapter analyzes a series of paintings from a scrapbook in the Eric Koch fonds found at Library and Archives Canada (LAC). The compilation includes poems, drawings, play scripts, sheet music, and paintings from many Jewish internees. The entries are in both English and German. Amongst the artwork are sketches, pen drawings, and watercolour paintings. This scrapbook serves as a physical manifestation of the community of artists and the individual and communal expressions of frustration, anguish, and monotony within different internment camps. The paintings serve as one example of the many forms of creativity and the arts, which also included such things as theatre productions and musical performances found within the various Jewish internment camps in Canada during the Second World War. After internment, these paintings also came to serve as part of Jewish refugee Eric Koch's memory building process, representative of the struggles of internment life, and a method of protest of their situation as refugees in Canada.

This chapter first outlines how the arts and educational activities contributed historically to the development of an internment community. It then delves into the artwork created and what conclusions can be drawn from these pieces. I look specifically at artwork as it is a medium from which many conclusions can be drawn and provides a window into the impact of creativity during this period. Among other things, I explore how the artwork provides an understanding of the emotional turmoil felt by the internees. Finally, I also look at the making and preserving of the paintings as practices. 
In doing so, I explore how they contributed to the construction and reconstruction of community and also as a form of protest within internment experiences.

My analysis contributes to a rich literature on internment history in Canada and the role art and creativity played. Paula Draper writes how camp artists, like Oscar Cahen, who later co-founded Canada's Painters Eleven, polished their talents by illustrating camp newspapers and decorating barren huts. ${ }^{1}$ Christine Whitehouse provides an interesting discussion on space and place in internee artwork and its connections to the internees' sense of belonging in Canada. For example, by using Oscar Cahen's 1942 work, Whitehouse argues that many of the landscape paintings connected to the internees' fondness of working as lumberjacks and being part of a larger tradition of pioneering. ${ }^{2}$ Drawing from the work of James Opp and John C. Walsh, Whitehouse argues that the depicted sites "are the physical links between collective memory and identity. ${ }^{\prime 3}$ Whitehouse focuses on the reconfiguration of the camps to suit the needs of the internees and how representations of the landscape help ground the former internees' identity within a Canadian narrative. Many of the paintings do this, and several of the sketches within Eric Koch's scrapbook also focus on "Canadian" landscapes. However, what is striking is other artwork from the same collection that represents the camp as a "place" in different ways: barbed wire, beaches, and internment

\footnotetext{
1 Paula Jean Draper, "The 'Camp Boy's: Interned Refugees from Nazism," in Enemies Within eds. Franca lacovetta, Angeloa Principe, and Roberto Perin (Toronto: University of Toronto Press, 2000), 180. 2 Christine Whitehouse, 'YYou'll Get Used to It!': The Internment of Jewish Refugees in Canada 19401943" (PhD diss., Carleton University, 2016), 53.

${ }^{3}$ Whitehouse, "'You'll Get Used to It!'," 55; James Opp \& John C. Walsh, eds. Placing Memory and Remembering Place in Canada (Vancouver: UBC Press, 2010).
} 
beds. I argue that these markers of place were done to reimagine and critique the internees' position within the space of internment.

Outside of scholarly writing, a number of internees have documented their camp experience and explored the roles that education and art played in camp life. ${ }^{4}$ For example, Erwin Schild recounts:

[Circumstance] not only facilitated an excellent standard of secondary and post-secondary education for the students, but it also enabled the camp community to organize a variety of cultural and educational programs, with the help of numerous artists, musician, and other talented people. ${ }^{5}$

Walter Igersheimer, a former internee of Camp L, recounts an art exhibition that was sponsored by Piggy Wiggy (Major L.C.W. Wiggs). ${ }^{6}$ The artists made portraits, landscapes, oil paintings, sculptures out of minimal supplies. Igersheimer remembers the mayor of Quebec attending and paid fifty dollars for a portrait. ${ }^{7}$ Of the published memoirs, Koch and Igersheimer present internee artwork as part of their explanations of camp life and education. Igersheimer provides some discussion on the artwork, which will be analyzed later in the chapter. However, analysis of the artwork itself is largely left untouched in both sources. What is prominent in these recollections is the importance of community and education in the creation of the artwork. Oscar Cahen provided illustrations for the newspapers that were widely distributed, art was taught by professionals in a classroom

\footnotetext{
${ }^{4}$ Alfred Bader Adventures of a Chemist Collector (London: Weidenfeld \& Nicholson, 1995); Walter W. Igersheimer, Blatant Injustice: The Story of a Jewish Refugee from Nazi Germany Imprisoned in Britain and Canada during World War II (Montreal \& Kingston: McGill-Queen's Univeristy Press, 2005); Eric Koch, Deemed Suspect: A Wartime Blunder (Toronto: Metheun, 1980); Erwin Schild, The Very Narrow Bridge: A Memoir of an Uncertain Passage (Canada Adath Israel Congregation/Malcom Lester, 2001);

${ }^{5}$ Schild, The Very Narrow Bridge, 223.

${ }^{6}$ Major L.C.W. Wiggs was given the nickname Piggy-Wiggy because of his corpulence.

${ }^{7}$ Schild, The Very Narrow Bridge, 223.
} 
setting, and the internees created an exhibition to raise money for the Queen's Canadian Fund for Air Raid Victims. ${ }^{8}$

Jewish internee art has also appeared within the broader public culture. The Vancouver Holocaust Education Centre's online exhibit Enemy Aliens presents a collection of the artifacts and paintings for educational purposes. ${ }^{9}$ Many of the paintings in Eric Koch's scrapbook are presented on the Enemy Aliens exhibit amongst government documents, military reports, internee made handicrafts, and testimonies of the Jewish internees. The exhibit explores many aspects of the internment experience. The "Camp Boys" section, spreads the artwork amongst different dossiers surveying education, work, religion, politics, and morale within the different internment camps. While there is minimal discussion on the paintings themselves, the exhibit allows for students and educators to explore and draw conclusions as to the purposes behind the artwork. Additionally, the New Brunswick Internment Camp Museum website hosts a gallery of images of photographs, artifacts, arts and crafts, furniture, and jewelry boxes found in the camp. ${ }^{10}$ The New Brunswick Internment Camp Museum will be discussed more fully in the final chapter of this thesis within a conversation concerning the space of which the post-internment community occupies.

\section{Internment and Community}

In his memoir Eric Koch argues,

\footnotetext{
${ }^{8}$ Igersheimer, Blatant Injustice, 104.

${ }^{9}$ VHEC exhibit “'Enemy Aliens': The Internment of Jewish Refugees in Canada, 1940-43," http://www.enemyaliens.ca/.

${ }^{10}$ NB Internment Camp Museum, http://nbinternmentmuseum.com/.
} 
Most of us feel that the years spent in this compression chamber between Europe and North America, between Hitler and the post-war world, taught us a great deal about ourselves and about the way a community works. ${ }^{11}$

To Koch, camp provided internees an opportunity to meet men they probably would not have met otherwise. He describes the varying groups amongst the internees in Camp N, the most common being the orthodox Jews and the Cambridge clique. ${ }^{12}$ While there were differences, Koch insists that the groups shared common goals and frustrations. Koch is not alone in this respect. Walter Igersheimer recounts in his memoir that one internee stood up in camp and presented a poem describing how the internees felt about being left behind in Canada. ${ }^{13}$ In this instance, poetry served as a unifying force in expressing internees' frustrations.

Many camp newsletters illuminate the importance of togetherness for the internees, including the Camp L Chronicle issues found in Hans Warschauer's fonds. In Camp L Chronicle number two, published on 2 October 1940, on the occasion of the dismantling of Camp L, there appeared a series of articles written in both English and German mixed amongst internee artwork. ${ }^{14}$ In one article, "Goodbye Camp L," the author and internee, Hans Kahle, explains how those of different creeds, upbringing, and social classes stood together. While there was friction that led to loud discussions that were sometimes violent, these conversations took place to solve the important

\footnotetext{
${ }^{11}$ Koch, Deemed Suspect, 168.

${ }^{12}$ Koch, Deemed Suspect, 168.

${ }^{13}$ Igersheimer, Blatant Injustice, 134.

${ }^{14}$ Camp L was dismantled to split the Jewish refugees and Nazi sympathizers up.
} 
issues of the camp, such as changing their Prisoner of War status. ${ }^{15}$ Kahle concludes by

writing on the issue of being split from Nazi sympathizers in the camp,

I wish to name as proof of the good work for the community our post office, the canteen, the banking office and last but not least both kitchens. One could write a long gastronomic history from the cold bullybeaf [sic.] of our famous first night in Camp $L$ to the splendid three course Sunday dinners of the last weeks ... We know each other by now, we have lied, suffered, laughed and worked together. We have built up a sound and efficient community. This moral asset should by no means be destroyed! $!^{16}$

Many internees remark that different work schemes gave them a sense of importance.

Fritz Wihl discusses how he was able to "gain muscles" after his work to haul lumber out of the woods. ${ }^{17}$ Christine Whitehouse argues there was a strong presence of a camp hierarchy and a lingering tension between laboured work and educational schemes within the camp. ${ }^{18}$ While there were differences, there were a number of common goals and issues in internment that surpassed these differences. This is not to discredit the divide and tensions, and such things are not evidence of a lack of community but in fact constitutive of the power relations inherent in all social forms of social organization. ${ }^{19}$

In Harry Rasky's documentary, The Spies Who Never Were, many internees are interviewed about their camp experience. The role of music was a central theme. Exinternee Helmut Blume said music was of great importance not only to the musicians

\footnotetext{
15 “Goodbye Camp L," Camp L Chronicle, October 2, 1940, Correspondence (English) 1938-1941, Heinz Warschauer's personal correspondence, Library and Archives Canada (LAC), Heinz Warschaur's personal correspondence 1932-1978, MG 31 D-129, Vol. 1.

16 “Goodbye Camp L," Camp L Chronicle, October 2, 1940, LAC, MG 31 D-129, Vol. 1.

${ }^{17}$ Fritz Wihl, "My life as a Refugee-Internee," 5, Wihl, Fritz Autobiographical note on his internment, n.d., Eric Koch fonds, LAC, MG 30 C-192, Vol. 1.

${ }^{18}$ Whitehouse, "'You'll Get Used to It!'," 88.

${ }^{19}$ John C. Walsh and Steven High, "Rethinking the Concept of Community," Social History/Histoire Sociale 32, no. 64 (1999): 257.
} 
but also to the camp as a whole. He argues in that "particular atmosphere, in the environment of uncertainty and a bit of fear which any type of a prisoner behind barbed wire would feel, music helped a great deal to re-establish a kind of a balance and a kind of hope." ${ }^{20}$ Internees were able to influence the atmosphere of each camp, despite the negative environment, through the use of music. Evidence of this also appears in Eric Koch's fonds. Helmut Kallman sent to Koch the introduction to one of the many plays performed in Camp N titled "The First Legion," written by Emmet Lavery. The introduction reads:

'The First Legion' does neither convey any tendency nor are its contents linked to any particular creed, - in spite of the milieu of this play. It's main problem, the miracle of faith, should have to all of us who are in need of steadfastness in these difficult times a close and profound meaning. ${ }^{21}$

The introduction exemplifies the acknowledgement of the differences in beliefs amongst those in the camps, but a higher importance is placed on the perceived shared needs of the internees as a whole.

The educational and group-focused activities demonstrate the presence and important of community within the internment camps. The paintings within Eric Koch's scrapbook illustrate the struggles of internees and lend to an insight into the collective experience of the ex-internees. While the following paintings reflect the journey to internment and internment life, they are not rooted in a specific place, which reflects their struggle to create an identity during internment. But in the context of what we

\footnotetext{
20 "The Spies Who Never Were," Part II, transcript, 18, LAC, MG 30 C-192, Vol. 3.

${ }^{21}$ Emmet Lavery, "The First Legion," August 3, 1942, Kallmann, Helmut Introduction to play produced in camp and list of actors, 1942, LAC, MG 30 C-192, Vol. 1.
} 
have seen so far, I argue that this identity was not merely that of the individual artist, but also an expression of community - of shared experiences, struggles, and frustrations. They were survivors of the war, but they were not concentration camp survivors; they were not prisoners of war, but not refugees. These paintings allude to this challenging identity. Finally, we shall also see how deeply gendered this artwork is, focusing on instances of lost masculinity, gendered racism, and a lack of female presence in their internment.

\section{Reflections of the Journey}

The journey to internment is expressed in Figures 1.1 and 1.2. Figure 1.1

illustrates two machines that turn the internees from civilians into prisoners of war and then into soldiers. The soldiers descend into a coffin labeled AMPC (Auxiliary Military Pioneer Corps). Internee Walter Igersheimer explains that he and other internees were offered release from internment if they volunteered with the Pioneers and provided manual labour for the British army. However, he declined because the British did not offer citizenship and if caught as a soldier by enemy forces he would have been shot as a Jew. ${ }^{22}$ In his memoir, Igersheimer elaborates on the coffin in Figure 1.1 as it "suggests the view that since unarmed pioneers were often assigned to dig trenches or clear roads at the front, they were cannon fodder." ${ }^{23}$ Accepting this offer was in a way viewed as a death sentence. This coffin could also be seen as a crate for shipping military resources.

\footnotetext{
22 Igersheimer, Blatant Injustice, 149.

${ }^{23}$ Igersheimer, Blatant Injustice, 149.
} 


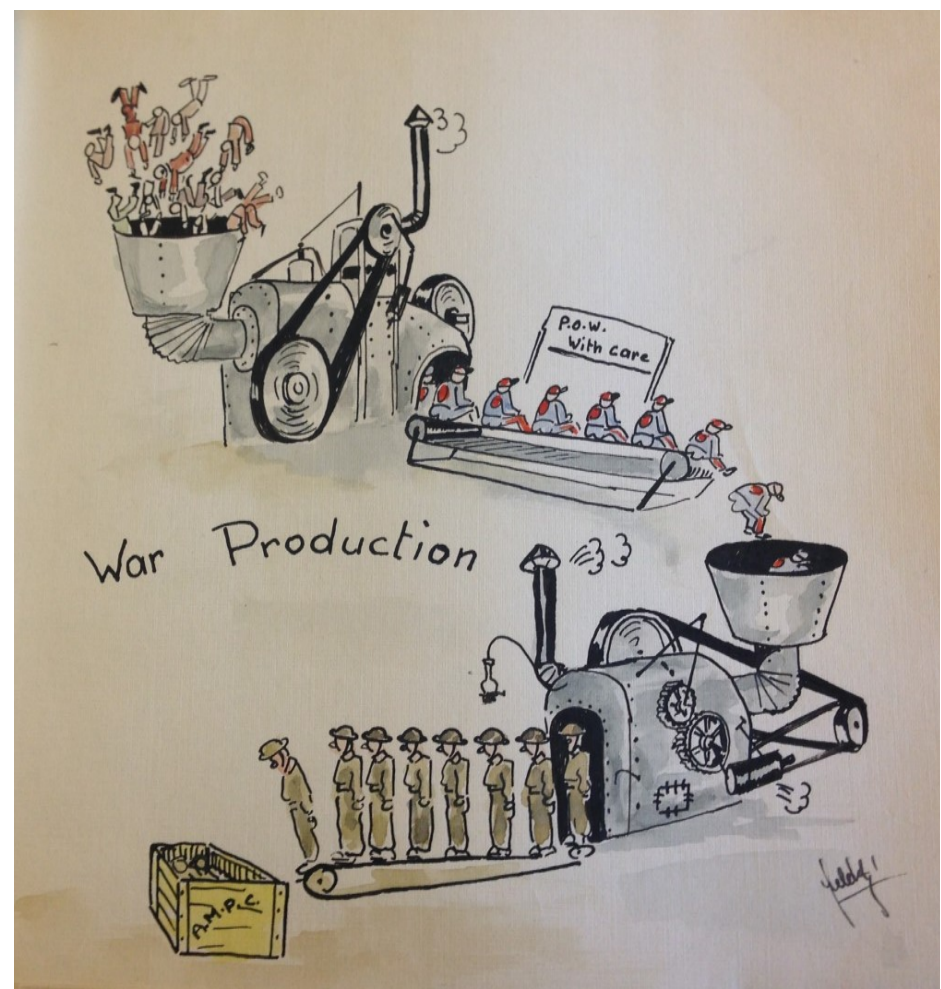

Figure 1.1 Untitled, Behind Barbed Wire Scrapbook, LAC, MC30 C-192, Vol. 2.

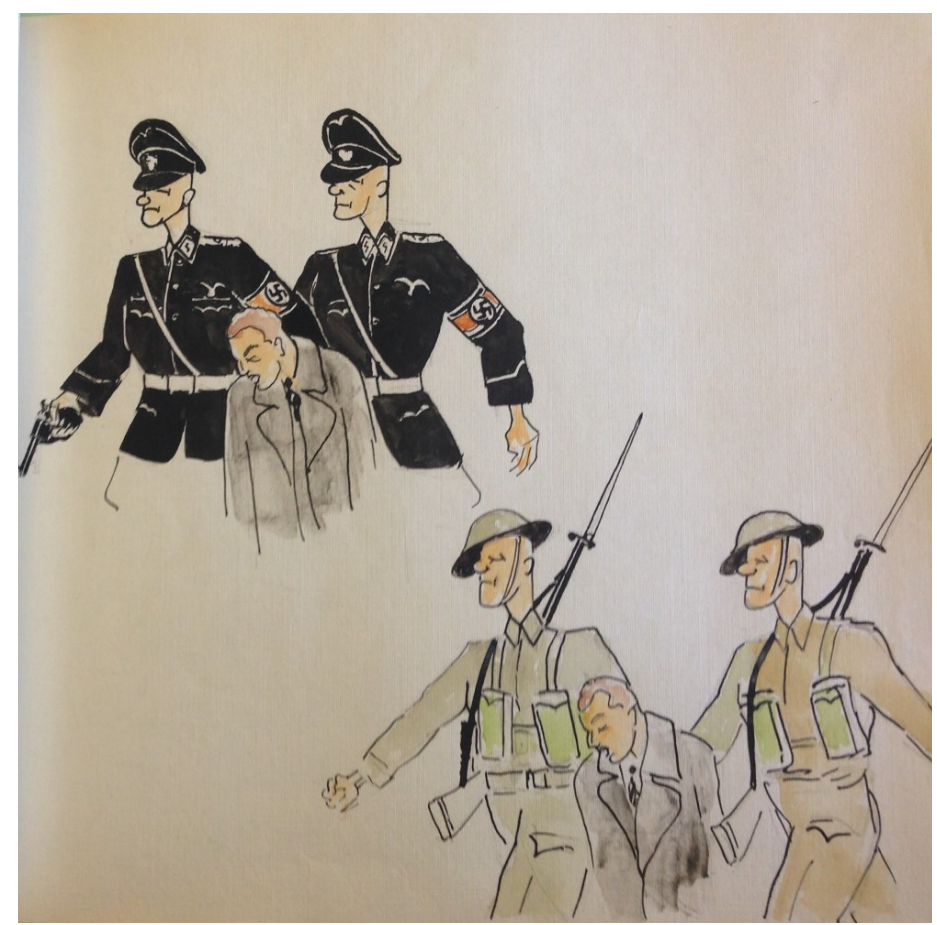

Figure 1.2 Untitled, Behind Barbed Wire Scrapbook, LAC, MC30 C-192, Vol. 2. 
Figure 1.2 illuminates similar grim assumptions of the internees' future in Canada. It depicts a man being moved by two Nazi soldiers above and the same man being moved by presumably two Canadian soldiers below. The context of the Nazi and presumed Canadian soldiers suggests that the man is a Jewish refugee in transport. This painting shows the reality of him as a hazard to these soldiers, but also plays on the ridiculousness of such a threat. The man appears submissive and his figure is much smaller than the overbearing guards. The stark contrast between the man and both sets of guards leads the viewer to question the necessity of such treatment depicted. In both images, the soldiers appear as larger, stronger, and more powerful. The constant is the smaller, weaker, powerless Jewish male prisoner.

A much broader critique of the political handling of wartime Jewish refugees is posed in this painting. These paintings portray the Jewish civilians' role in the "war production" as routinized and without agency. The evolution of clothing colour in Figure 1.1 changes from civilians at the top with bright and unique outfits, to the uniformity of Jewish internee outfits in Canada, to the bland soldier's uniform. This development speaks to the treatment of Jewish internees' during the process to internment as becoming less individualistic to more standardized and uniform. A conglomerate of both German and Austrian, the POW is a byproduct of the same mass industrial production that was churning their uniforms, munitions, and other elements of the war machine. Figure 1.2 complements this notion. While the viewer experiences more intimately the journey to internment, the painting reflects similar ideas of anonymity and loss of agency. By contrasting the man and the soldiers, the painter exemplifies the distance 
felt between him and the Allied and Nazi soldiers. Both groups of soldiers oppressed him as a Jewish man. Images such as Figures 1.1 and 1.2 illustrate the lack of agency Jewish people felt they had during the war, and the impact the war had on them. To the Jewish refugees, both the Allies and the Nazis were threats to their autonomy, their involvement in the war, and their individuality.

The value of the internees' personal reflections is helpful in interpreting the significance of these paintings. Figures 1.1 and 1.2 reflect the psychological damage caused to Jewish internees' through their initial treatment as Nazi sympathizers, and the continuation of the disillusionment of Allied "protection." What they were experiencing was not freedom; it was a further renunciation of whatever freedom and independence they were promised. They were viewed as Germans and Austrians, not refugees, amalgamated with the aggressive enemies. ${ }^{24}$ The Canadian government's decision to put them in the same category as those deemed untrustworthy continued the process of 'othering' for these refugees.

The lack of geographical grounding in both paintings is integral to the interpretation of these works. In Figure 1.2, the internee is being carried away by Nazi soldiers and British or Canadian soldiers. Leaving no geographical markers allows the viewer to place both the British and Canadian soldiers as the bottom two soldiers in Figure 1.2. The viewer sees the internee as he is potentially entering a concentration camp (as many of the internees had done previously), or being carried away to an internment camp in Huyton, England, or being dragged into a ramshackle Canadian

\footnotetext{
${ }^{24}$ Schild, The Very Narrow Bridge, 217.
} 
internment camp. This artwork, by not being rooted in an identifiable, specific place, was able to express many of the frustrations of internees across the nine internment camps. Similar to the previous discussion of community building through the arts in camp, these paintings serve as a unifying force for internees in the expression of some of their anguish.

\section{Sexuality and Heterosexual Desire}

The Jewish refugee's identity was constantly challenged and shaped by the influences of internment and this included their own bodily desires for sex and heterosexual companionship. ${ }^{25}$ Eric Koch remembers, "the absence of women had a very predictable influence on the lives of many inmates. The only way in which we could have heterosexual love affairs was in our fantasies." ${ }^{26}$ The following paintings are a manifestation of these highly sexualized fantasies. They also reflect a form of countering the reduction of masculine qualities within the camp confines. Each of these paintings portrays varying perspectives of the Jewish refugee and the viewer, while emphasizing the importance of the barbed wire and the position of bodies on other side of it.

${ }^{25}$ Koch, Deemed Suspect, 167.

${ }^{26}$ Koch, Deemed Suspect, 157. 


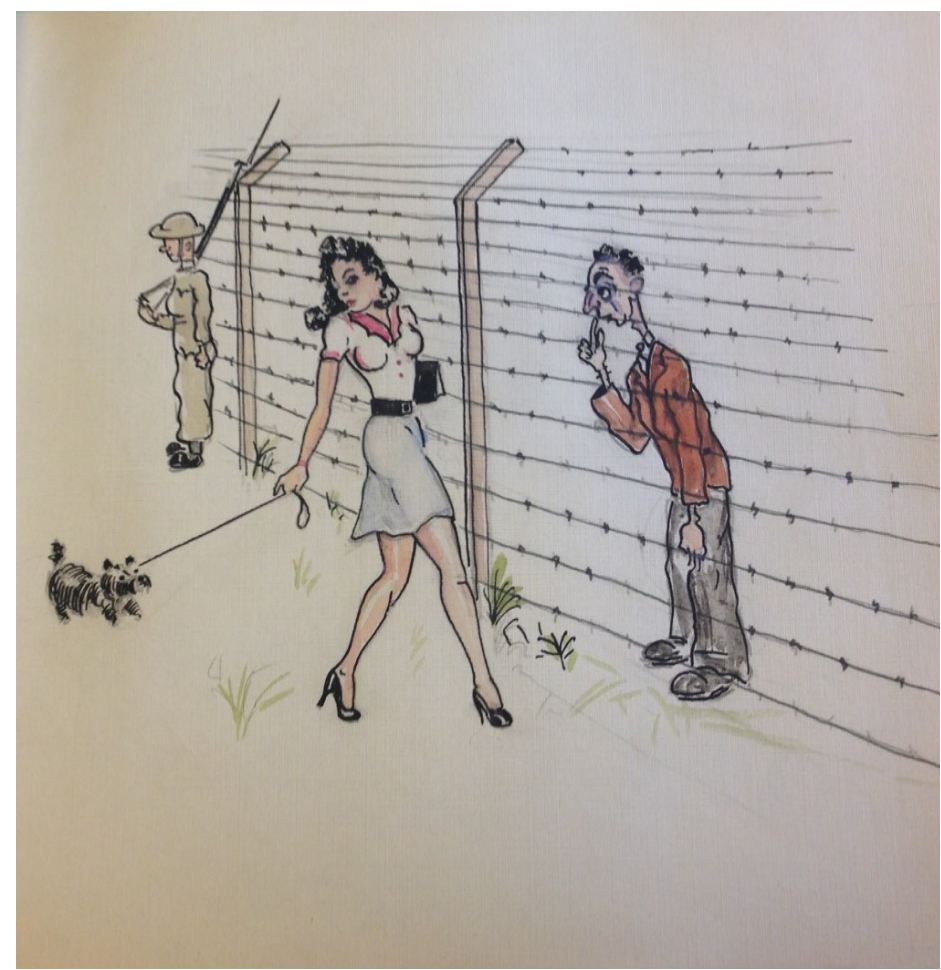

Figure 1.3 Untitled, Behind Barbed Wire Scrapbook, LAC, MC30 C-192, Vol. 2.

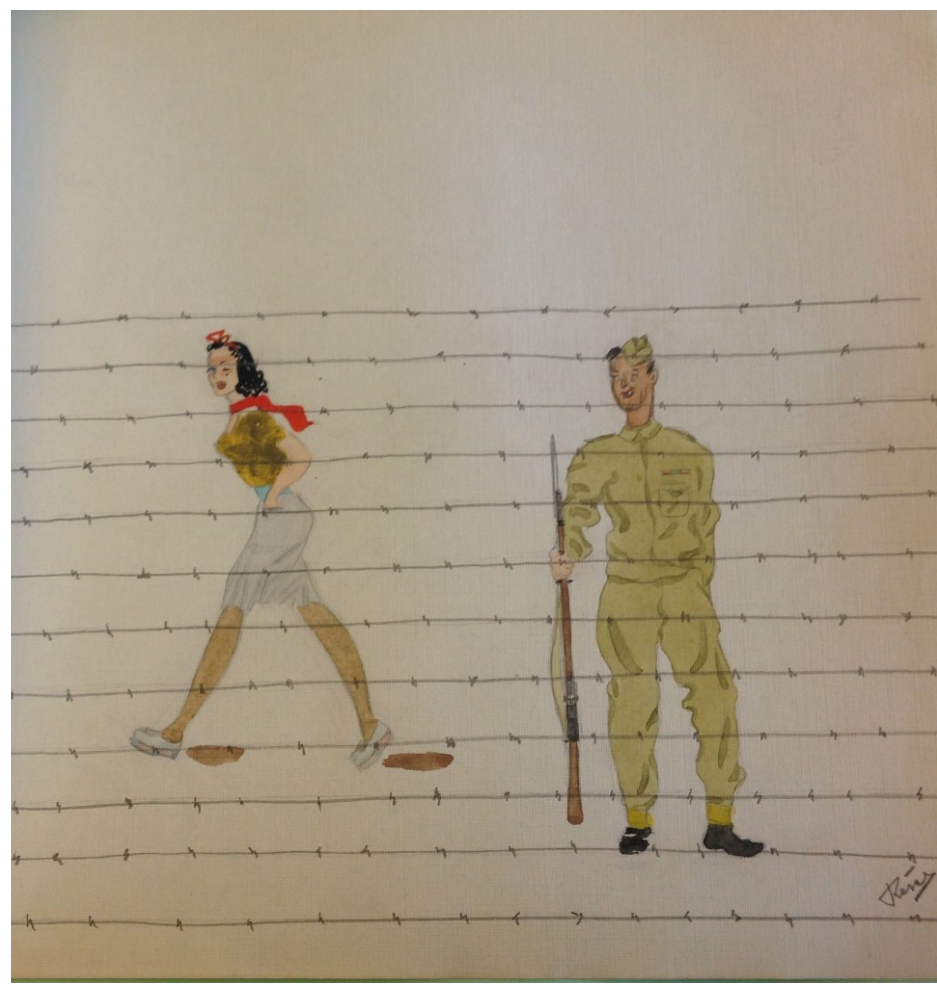

Figure 1.4 Untitled, Behind Barbed Wire Scrapbook, LAC, MC30 C-192, Vol. 2. 


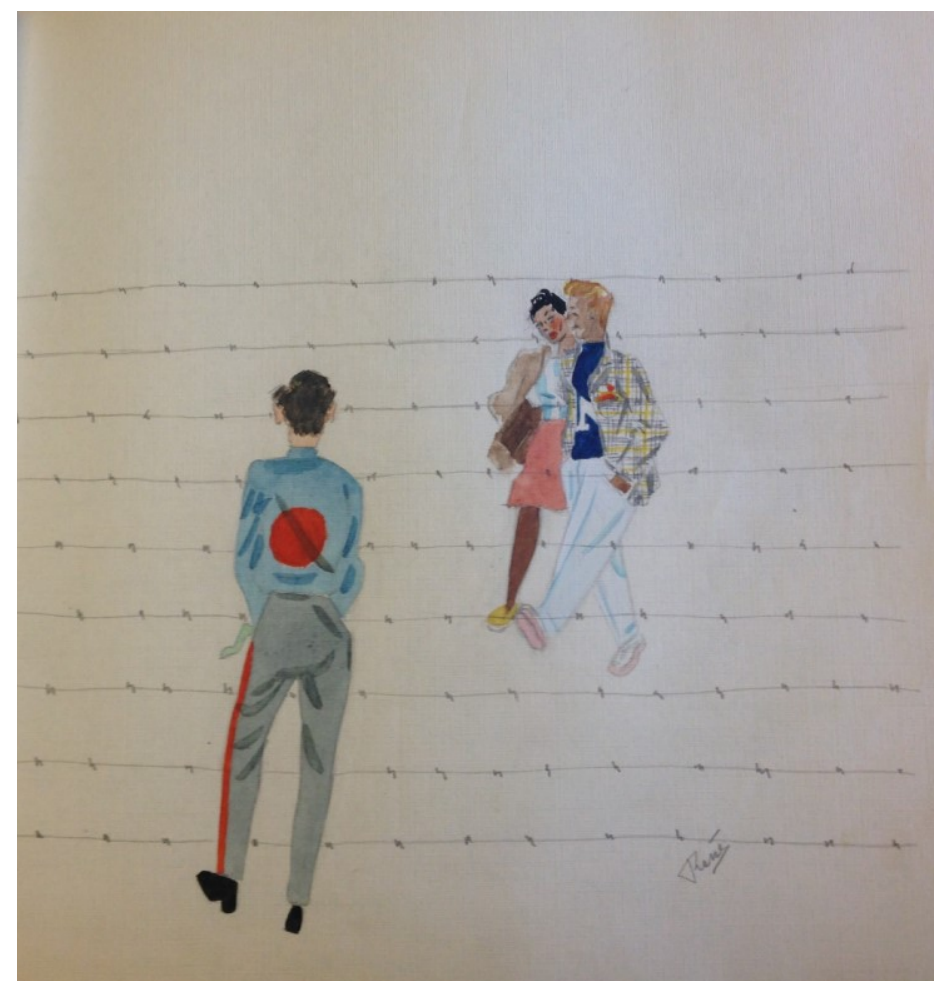

Figure 1.5 Untitled, Behind Barbed Wire Scrapbook, LAC, MC30 C-192, Vol. 2.

Internees often spent their days watching life pass by beyond the barbed wire.

Walter Igersheimer recounted the reactions of many Jewish internees watching women walk by the camp. Igersheimer described a situation in which the presence of a woman on the other side of the wire caused a commotion within the camp:

Occasionally she smiles at Freddy [another Jewish internee], who has gone off his nut, throwing kisses, shouting, showing off and dancing around. Other girls come and stop. More and more internees are drawn to this side of the camp, until the mass of people alerts the guard, and the girls are told to move along. This they finally do, languidly swinging their sexy hips. ${ }^{27}$

Igersheimer's description of this situation is almost comical, and it certainly lightens the way these paintings can be viewed. While the internee in Figures 1.3 and 1.5 is reflected as almost a dirty onlooker, Igersheimer's playful memory allows the viewer to

\footnotetext{
${ }^{27}$ Igersheimer, Blatant Injustice, 67.
} 
potentially interpret these paintings as not only an expression of longing beyond the barbed wire, but also a solidification of their daily experiences with women outside the camp. Memories such as these serve to complicate our interpretations of and meaning behind these paintings, while contributing to a fuller understanding of the nature of internment.

Figure 1.3 depicts a woman walking along the barbed wire of an internment camp with her dog. A soldier guards the fence in the background, while an unkempt internee is pictured gawking at the woman strutting by. The voluptuously painted woman is contrasted with the internee who is represented as almost a dirty onlooker. Figure 1.4 is similar in that it depicts a well-dressed and vibrant woman walking beyond the barbed wire. This time the soldier on guard is shown watching her intently as she passes by, while holding his rifle in a relaxed position. In Figure 1.5 the viewer is positioned a few steps behind the back of the internee who is peering through the barbed wire at the couple walking near the camp. The internee's hunched posture with hands hidden and the presence of a light green unidentified form next to him at his waistline requires attention; it is possible that the internee may be masturbating, and the couple outside the barbed wire is the subject of his fantasy. In such a reading, this painting may also reinforce the idea of a voyeur and portrays internees' sexual desires as little more than fantastical longing for something absent from their everyday lives in the camp. The positioning of the viewer in each of these paintings is distinct and complicates our understanding of this specific history of interment. As many internees expressed, the process of internment was dehumanizing and took a toll on them 
psychologically. The expressions of longing and desire, mixed with the uncomfortable positioning of the internee exemplify the multifaceted components of this human experience.

In each of these paintings, the eye contact between characters is striking. Figure 1.4 shows the male soldier looking onwards at the woman who is walking away as she looks at the viewer. In contrast Figure 1.3 shows the internee looking on intently at the woman, while she has turned her head to look away from him. Similarly, in Figure 1.5 the internee is concentrating on the heterosexual couple. The heterosexual couple walking beyond the barbed wire shows a blonde man looking away, while the direction of the woman's gaze points to either the blonde man or the internee. However, because the couple is fused together almost as one defined object and operating as a single form the argument could be made that she is looking at the blonde man and not the internee. The various levels of eye contact and interaction amongst the characters speak to an acknowledgement of each person's presence within the internment experience. The avoidance of eye contact with the internee speaks to the uncomfortable nature of viewing the outside world, especially when the events that occur embody the sexual desires of the internees.

In the work on fascination and fetish, pleasure in looking is split between the active/male and the passive/female. ${ }^{28}$ Traditionally the male (or voyeuristic) gaze

\footnotetext{
${ }^{28}$ Laura Mulvey, "Visual Pleasure and Narrative Cinema," in Film Theory and Criticism: Introductory Readings, eds. Leo Braudy and Marshall Cohen (New York: Oxford University Press: 1999): 837. See also: Amelia Jones, Seeing Differently: A history and theory of identification and the visual arts (New York: Routledge, 2012); Sigmund Freud, "Fetishism," in The Standard Edition of the Complete Psychological Works of Sigmund Freud: The Future of an Illusion Vol. 21, ed. James Strachey (London: Hogarth Press, 1961), 147-158.
} 
projects its fantasy onto the woman who is simultaneously looked at and displayed.

Thus, in the act of looking there is a power struggle, with the one who is being looked at as the one without the power. The voyeuristic gaze in Figures 1.3 to 1.5 is unmistakable, yet distinct in each image. The internees in Figures 1.4 and 1.5 come to embody this notion of voyeur, while the viewer is pushed into that position through Figure 1.3. Like the uniform as a marker of distinction in Figure 1.5, the internee in Figure 1.3 shares similar qualities. These paintings emphasize the alienation, feeling of inadequacy, and awkward position in watching these events occur beyond the internees' reach. In light of this, the internee can be perceived as a voyeur of the occurring events beyond the barbed wire.

It also suggests the internee felt the fence presented them as a second-class citizen, or even a non-person, to a woman they might have pursued romantically in a different context. Distinguishing the Jewish body as different has been present in the earliest Christian texts, which, as Sander Gilman argues, enabled this rhetoric to exist through the ages. ${ }^{29}$ It was the development of the science of race that changed the rhetoric from religious to secular differences. ${ }^{30}$ The act of circumcision contributed to the Jew as the outsider, being seen as sexually apart. ${ }^{31}$ Not only was the Jewish male body seen as separate, or "other," the trope of the effeminate Jewish man had a significant impact on Jewish men's self-identity. ${ }^{32}$ Within this context of "othering" the

\footnotetext{
${ }^{29}$ Sander Gilman, The Jew's Body, (New York: Routledge, 1991), 235.

${ }^{30}$ Gilman, The Jew's Body, 235.

${ }^{31}$ Gilman, The Jew's Body, 119.

32 Benjamin Maria Baader, Sharon Gillerman, and Paul Lerner, "Introduction," in Jewish Masculinities: German Jews, Gender, and History, eds. Benjamin Maria Baader, Sharon Gillerman, and Paul Lerner (Bloomington \& Indianapolis: Indiana University Press), 2.
} 
Jewish male body these paintings come to illustrate an extension of a long established rhetoric of the Jew as different. The non-Jewish bodies in the paintings reinforce these longstanding ideals of difference. In Figure 1.3 while the Jewish internee is hunched over and dressed in ragged clothing, the soldier stands tall in the distance. While the soldier's stance in Figure 1.4 is relaxed, his presence is large and overbearing in the illustration. While the blonde man in Figure 1.5 is colourfully dressed and moving freely with a woman around his arm. The presence of the internee's uniform in Figure 1.5 is a blatant reminder for the viewer that he is different. It disconnects the viewer from the internee and encourages an uncomfortable reminder that no viewer, and no contemporary viewer, would be able to comprehend his perspective.

The fence separating the couple and the Jewish internee remains a physical barrier between the internee and the outside environment. However, its presence in this painting demonstrates the depth of its impact. It serves as a reminder of the psychological barrier present in the life of Jewish internees. In his history of the uses of barbed wire in the method of containment, Reviel Netz argues a main tenet of history is the prevention of motion. ${ }^{33}$ Within this is a desire for control of a mass of people. Having our motion prevented is unpleasant and painful at the basic biological level, incites violence and pain on a mass scale. Violence did not manifest itself very often within these internment camps, but the pain was ever-present. As internee Erwin Schild wrote, their pain was psychological and profound. ${ }^{34}$ In its role of preventing motion, one

\footnotetext{
${ }^{33}$ Reviel Netz, Barbed Wire: An Ecology of Modernity (Connecticut: Wesleyan University Press), 229.

${ }^{34}$ Schild, The Very Narrow Bridge, 222.
} 
of the main political uses of the barbed wire is to reinforce asymmetry. ${ }^{35}$ On one side stands an all-powerful government, and on the other, a defeated and unarmed group of people. ${ }^{36}$ The presence of the barbed wire in these paintings emphasizes a similar asymmetric relationship. Guards and women move freely on one side of the barbed wire with the freedom and power to move about as they please, while the internee stands powerlessly on the other side. The internee stands as the observer, while those who are observed are able to move about and quite gleefully, especially the women in each painting. The internee is motionless in the camp, as his life is put on hold while in internment, while he watches people and history move past him.

\section{Sexuality Behind the Barbed Wire}

Several of the paintings found in the scrapbook illustrate many of the qualities of a modern pin-up girl: voluptuous body features, sexualized positioning, and exuding confidence. It is almost a celebration of sexuality against a denigration of it in terms of the internees. The pin-up serves, "as an image that pointedly eliminates the explicit representation of a sexual act by both eliminating the presence of men (and, generally, other women) and strategically covering the genital area of the female subject." 37 These images of pin-up girls often reflect expected roles of women in the cultures and subcultures within which it is created. ${ }^{38}$

\footnotetext{
${ }^{35}$ Netz, Barbed Wire, 130.

${ }^{36}$ Netz, Barbed Wire, 130.

${ }^{37}$ Maria Elena Buszek, Pin-Up Grrrls: Feminism, Sexuality, Popular Culture (Durham and London: Duke University Press, 2006): 11.

${ }^{38}$ Buszek, Pin-Up Grrls, 5.
} 


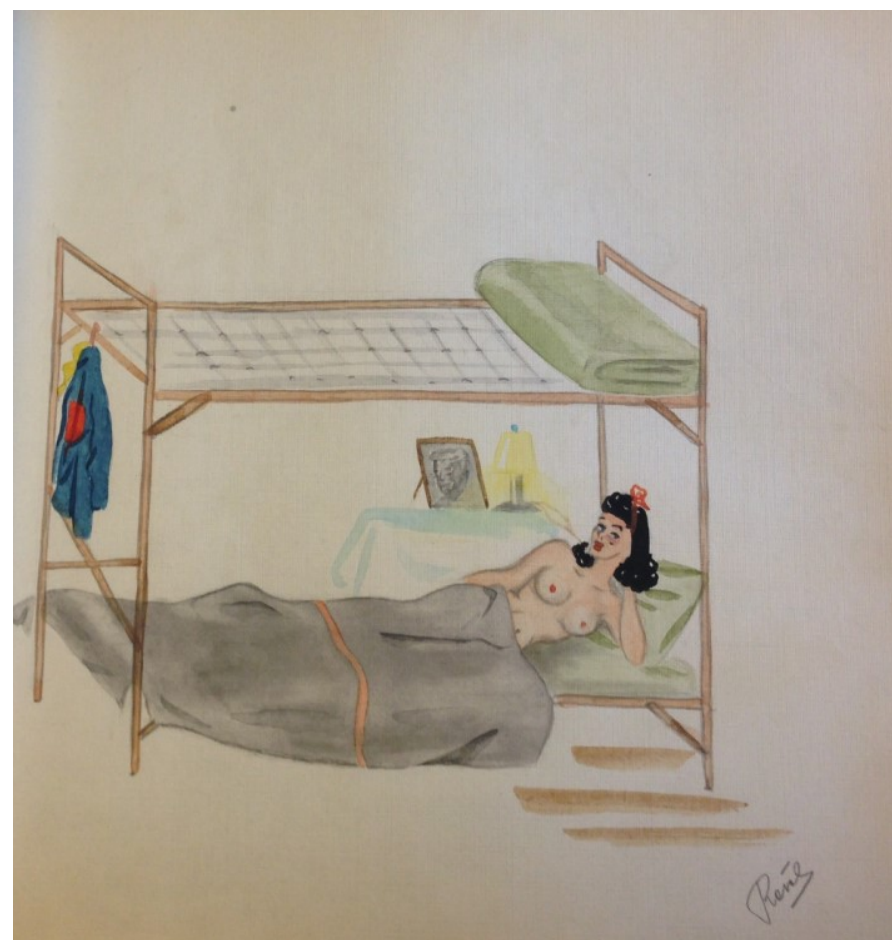

Figure 1.6 Untitled, Behind Barbed Wire Scrapbook, LAC, MC30 C-192, Vol. 2.

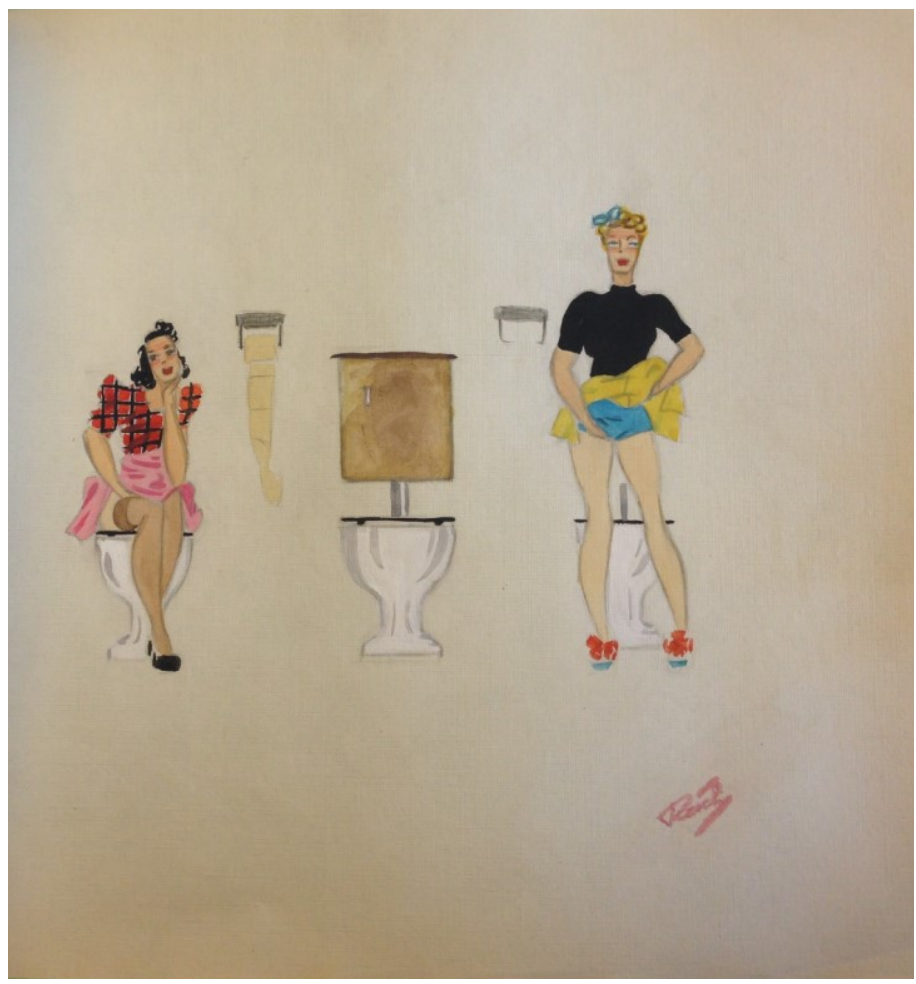

Figure 1.7 Untitled, Behind Barbed Wire Scrapbook, LAC, MC30 C-192, Vol. 2. 
The juxtaposition of these sexualized depictions with elements of internment life emphasizes the power of confinement over the imaginations of internees. Figure 1.6 illustrates a naked woman lying in an internment bunk bed with her breasts exposed. Walter Igersheimer included this painting in his memoir and commented on the "hated prisoner of war uniform hanging from the bunk bed." 39 The contrast between the nudity and the "hated" prisoner of war uniform increases the taboo nature of the depiction. A similar distinction is illustrated in Figure 1.7. The women are depicted in what can be assumed is the communal washrooms many of the internees described in the camps. One of the women standing in the washroom looks like she is pulling up her underwear to fix her skirt, while the other is sitting on the toilet. However, it appears both women could be masturbating. Both paintings are exposing female body parts in places where male masturbation could have taken place: the internee bed and the communal washroom. By doing so the paintings are speaking to the relationship between space, bodily function, and fantasy. The internees were able to 'bring' women into their sleeping quarters and communal washrooms that internees often complained about as a reduction of their privacy. ${ }^{40}$

The artist was strategic in the placement of specific objects of internment to ground the painting in a specific place, while maintaining its fluidity and adaptability to each internment camp. We see the presence of the internee bunk bed and the bathrooms, which had no privacy, yet they are not bound to a specific internment camp. These are artifacts that each internee could recognize and identify with. Even if an

\footnotetext{
${ }^{39}$ Igersheimer, Blatant Injustice, 150.

${ }^{40}$ Igersheimer, Blatant Injustice, 77-78.
} 
internee had homosexual tendencies and did not desire for the presence of women, the stark contrast between the elements of internment and femininity is unavoidable and the lack of female presence was obvious.

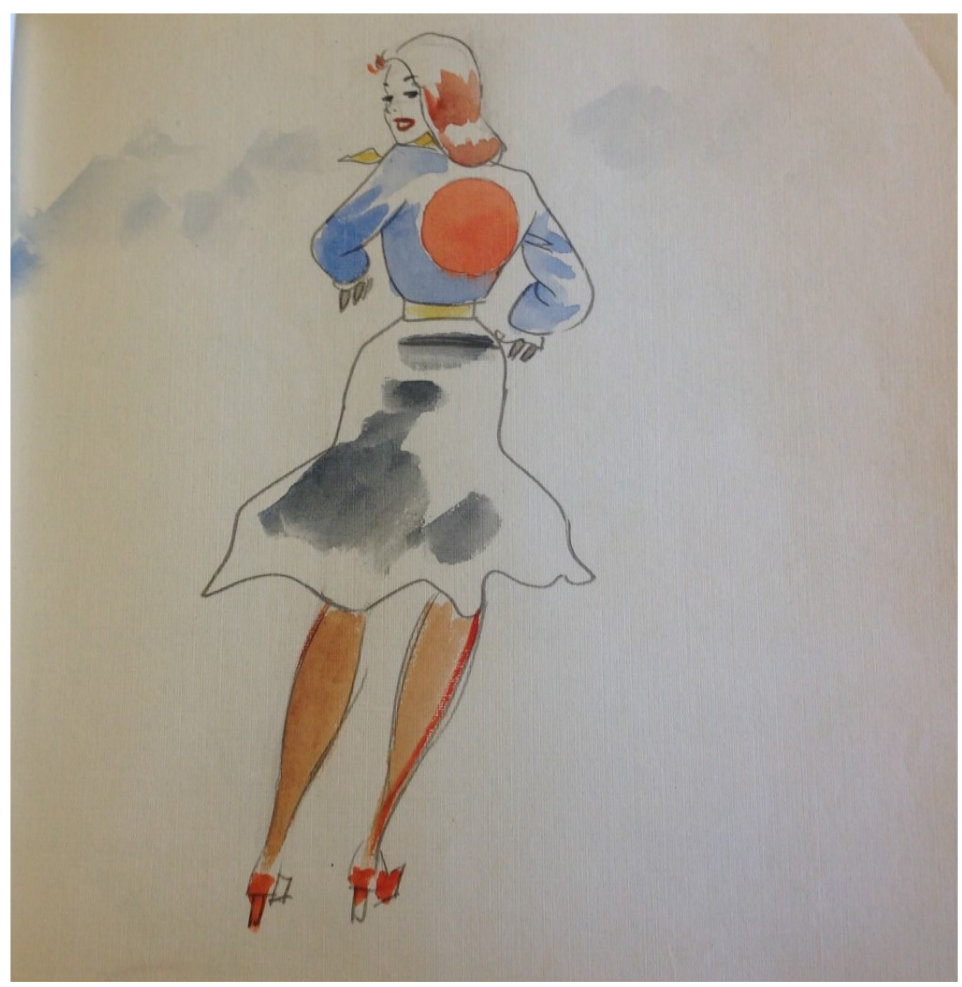

Figure 1.8 Untitled, Behind Barbed Wire Scrapbook, LAC, MC30 C-192, Vol. 2. 


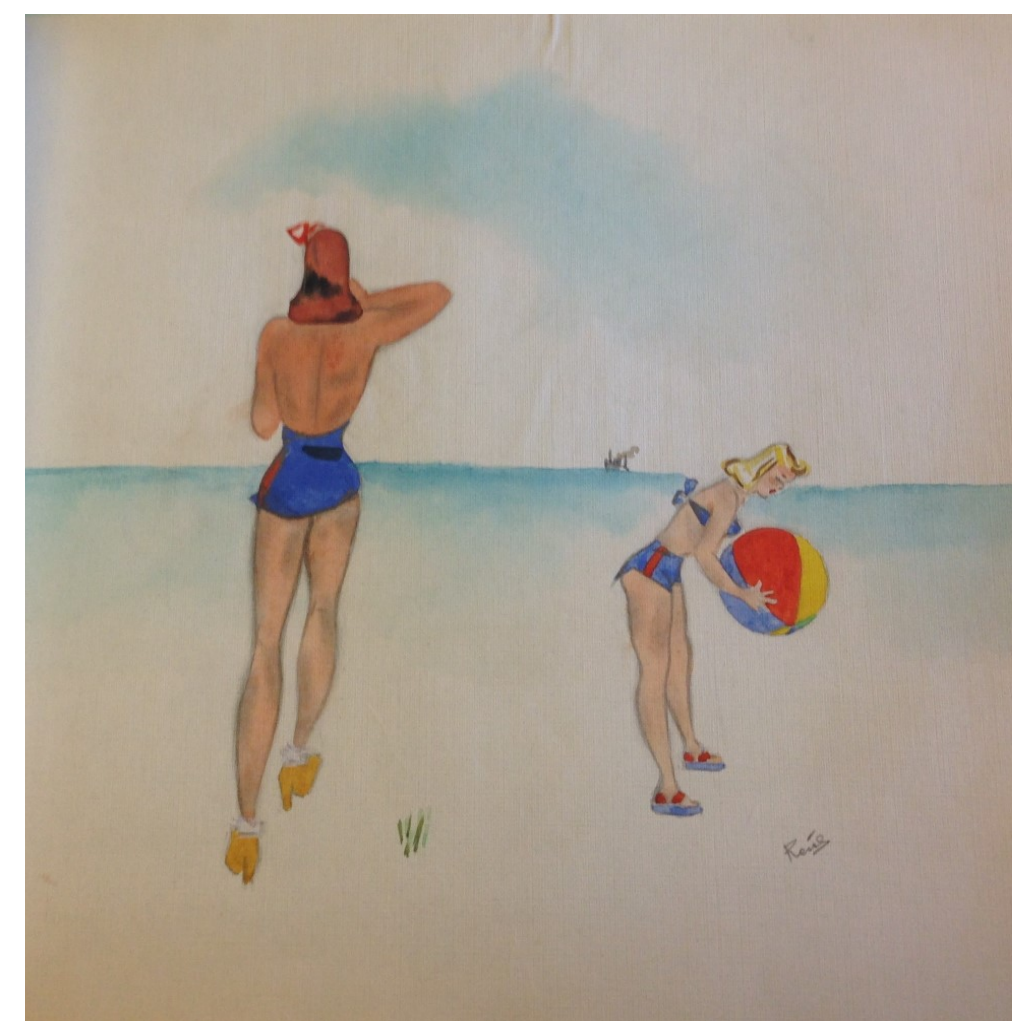

Figure 1.9 Untitled, Behind Barbed Wire Scrapbook, LAC, MC30 C-192, Vol. 2.

The shift in female representation during the Second World War meant that women in pin-up illustrations were constructed as a sort of modern war goddess, reflective of the shift in women's roles. ${ }^{41}$ Similar to popular culture representations of women through the pin-up girl in America, the women depicted in Figures 1.8 and 1.9 come to bear the role not expected, but fantasized of them. Figure 1.8 illustrates the back of a woman who is wearing the prisoner of war jacket with noticeably bright red circle. Her head is turned to look back very directly and uncomfortably at the viewer. Figure 1.8 shows a beach scene with two women wearing bathing suits sporting the red and blue colours of the internees' uniform. Their casual dress (Figure 1.8) and relaxed nature at the beach (Figure 1.9) illustrates a yearning for a life beyond the wire.

\footnotetext{
${ }^{41}$ Buszek, Pin-Up Grrrls, 185-187.
} 
However, it is contrasted with their clothing, both with the "hated" internee jacket one woman wears and bathing suits with red stripes down the side similar to the internees' uniforms. These illustrations embody the difficulty of longing versus reality. While it is an expression of anguish and desire, the artists were able to challenge their situation by creatively placing women within spaces in which their presence was forbidden in an attempt to satisfy their sexual needs, and perhaps also imagining a life after the camps.

While the above analysis is an attempt to understand the motivations of the Jewish internees who created and consumed these images, it is important to recognize our limitations when drawing conclusions about those motivations. There were also practical reasons for internees to create artwork. The artwork is strong evidence of social capital within the camps, and for situating the producers and consumers of the paintings. Eric Koch remembers at Christmas time in Camp $\mathrm{N}$ that one of the camp artists drew a nude image for Sergeant-Major Macintosh, which apparently softened him up during the holidays. ${ }^{42}$ These images were powerful creations in their ability to be widely distributed and consumed.

American soldiers would carry pin-up photos with them during the Second World War. They used the anonymity of the women in these photos to identify with very real women back home. ${ }^{43}$ Similarly for the Jewish internees the anonymity would allow them to place real women in these sexualized depictions. Igersheimer recounted many internees who were in contact with women who lived outside of the internment camp. ${ }^{44}$

\footnotetext{
42 Koch, Deemed Suspect, 138.

${ }^{43}$ Buszek, Pin-Up Grrrls, 229.

${ }^{44}$ Igersheimer, Blatant Injustice, 228.
} 
In addition to anonymity was the placement of the POW uniform on the women. The anonymity of the women and the specificity of the POW uniform are powerful in their ability for internees to attach meaning to a specific woman and connect to the general internment experience. The depiction of these women as a form of "internment goddess" mimics the pin up girl wearing an army uniform. The Jewish internees demonstrated that they too can long for and input women in similar ways to regular soldiers.

The paintings are a physical manifestation of the Jewish internees' attempts to comprehend internment. They represent a reaction to their loss of agency and displacement. They also conceptualize how the internees understood their role in this process. Take Figure 1.1, for example, and the visualization of the "war machine." The box seen in the bottom left hand corner could represent a coffin or a crate for military resources. This painting is a creative representation of the reaction to the offer to return to England and response. It is a resistance to the war machine and the internment process. By refusing the offer to go back to England and serve in the Pioneer corps and stay in Canada, and processing these experiences through art, the artist was contributing to a formation of identity through resistance. By highlighting the process of the war machine and the POW uniform, the painting is powerful in bonding the internees together through the shared experience of internment. The paintings also contributed to the building of community and a common sense of identity beyond their ethno-religious identity. While "escaping" the confines of the camp through diversions 
they were simultaneously "escaping" the confines of their identity and redefining the elements of what made them a group.

\section{Art as a Masculine Protest}

Christine Whitehouse explores the concept of protest within the nine Canadian internment camps as they appear in the Vancouver Holocaust Education Centre's Enemy Aliens digital exhibition. In her discussion on handicrafts and resistance, she writes that the theme of resistance is pushed aside for a "more easily digestible understanding of their work as a welcomed distraction from the monotony of daily camp life." ${ }^{45}$ While I agree that there is more of a focus on monotony than protest, the purpose of the online exhibit as an educational resource encourages students to come to those conclusions themselves. In the downloadable teacher's guide for educators the students are required to discuss the artifacts and discuss what each source reveals about the internees' response to internment. ${ }^{46}$ This allows for the students to reach conclusions on their own, instead of being bogged down by the competing narratives.

Whitehouse's interpretation allows for an interesting discussion of what constitutes protest and resistance. I propose to understand protest and resistance on a spectrum. Resistance can be more ambivalent, such as an internee simply responding to a situation of internment by expressing his anguish through artwork. Protest, as is more commonly understood would appear more obvious. However, the acts that contributed to a build-up of an internee identity and the growing importance of community may

\footnotetext{
${ }^{45}$ Whitehouse, "'You'll Get Used to It!'," 166.

${ }^{46}$ Nina Krieger and Paula Draper, “'Enemy Aliens': The Internment of Jewish Refugees in Canada, 19401943," Teacher's Guide, 37.
} 
flow into the arena of protest. Thus, what may not be traditionally viewed as protest or resistance can be found in the evidence. By looking at these concepts in less black and white terms we are not only able to unravel pieces of the history of Jewish internment, but also appreciate the varying ways in which protest and resistance come to exist within these spaces.

As an example, challenging the monotony of camp life was a form of protest in itself. The repetitiousness of camp life was relieved through varying communal activities. Patrick Farges argues that through intellectual activities the men reestablished various masculine identities: "they could be productive, providers, or professionals again. In this way, they became "someone" again, thereby regaining some self-respect and dignity." ${ }^{47}$ Martin Auger writes, "education programs enabled prisoners to satisfy their thirst for knowledge. They kept inmates busy learning, making them less prone to concentrate on their captivity." 48 Many internees found that education gave them back some independence: "each single student who studies in an internment camp is his own master." 49 Creative activities behind barbed wire were "a therapeutic outlet which enabled [internees] to survive emotionally, psychologically, and, in some cases, physically."50 This was a way for the Jewish internees to become their own masters by being in control of what they were producing. By doing so they were

\footnotetext{
${ }^{47}$ Patrick Farges, "Masculinity and Confinement: German-Speaking Refugees in Canadian Internment Camps (1940-1943)," Culture, Society \& Masculinities 4, no. 1 (2012): 41.

${ }^{48}$ Martin F. Auger, Prisoners of the Home Front (Vancouver: UBC Press, 2009), 146.

${ }^{49}$ Auger, Prisoners of the Home Front, 148.

${ }^{50}$ Gilly Carr and Harold Mytum, "The Important of Creativity Behind Barbed Wire: Setting a Research Agenda," in Cultural Heritage and Prisoners of War: Creativity Behind Barbed Wire, eds. Gillian Carr and $\mathrm{H}$. C. Mytum (New York: Routledge, 2012), 2.
} 
counteracting the frustrations that they were expressing in the artwork: emasculation, lack of autonomy, and lack of female presence.

In her work on Japanese-Canadian internment, Pamela Sugiman argues that the notion of the silent and passive "Japanese woman is part of a race and gender essentialism that must be challenged." ${ }^{51}$ She demonstrates how private correspondence that had been intercepted and censored by Canadian government officials for Japanese women served "as a vehicle of self-expression, a means by which to convey feeling and articulate personal opinion." 52 What better way to protest and dispute Canadian treatment of interned Japanese than the act of writing a letter that would have been censored by a government official? Sugiman establishes how some acts of protest that can be perceived as passive ways of resistance, are highly effective in their purpose of expressing grief and frustration in different contexts.

There is a parallel between the letters written by interned Japanese-Canadian women and the paintings produced by interned Jewish men. In both cases, since they were under constant surveillance, everything the internees created, used, and read, was observed. The paintings speak to the treatment of the internees by Canadian soldiers, and the frustrations and desires within an-all male environment. We know the artists' guards saw the paintings as some guards were even given paintings by the internees. ${ }^{53}$ There was therefore a politics to this culture in the time and place in which it was produced. Within the confines of the all-male internment camps, these men

\footnotetext{
51 Pamela Sugiman, "Passing Time, Moving Memories: Interpreting Wartime Narratives of Japanese Canadian Women," Social History 37, no. 73 (2004): 57.

52 Sugiman, "Passing Time, Moving Memories," 60.

${ }^{53}$ Koch, Deemed Suspect, 138.
} 
renegotiated the appropriate form of protest and gained a mode of self-expression and autonomy. This parallel can be extended to the various other acts of creativity such as music, theatre, and education. The various productions and art classes established art as a way of protesting their situation by making the most of their situation. Instead of becoming captive to their geography, the internees sought to take control of the internment environment and have it serve their purposes.

As a method for self-expression, the act of painting therefore becomes a form of voice to the Jewish internees. This process is paralleled with the process of other forms of political commentary in internment. Pnina Rosenberg analyzes how graphic novels created by Horst Rosenthal during his time at Gurs camp in occupied France in the Second World War embody a political statement. The ironic and critical position of Rosenthal's graphic novels manifested as a form of defense and protest against the French authorities. Rosenberg argues that through creativity and imagination the inmate felt almost human, and they "could soar beyond the barbed wire fences that separated them, the undesirables, from the outside world." 54 Additionally, political cartoons share a similar purpose to the paintings as a creative act. Features of political cartoons are caricatures, humour, and a societal critique as its purpose..$^{55}$ In his history of political cartoons in Alberta, Hugh Dempsey writes, "cartoons are a visual form of

\footnotetext{
${ }^{54}$ Pnina Rosenberg, "Mickey Mouse in Gurs - Humour, Irony and Criticism in Works of Art Produced in the Gurs Internment Camp," Rethinking History 6, no. 3 (2002): 287.

55 David Keane, “Cartoon Violence and Freedom of Expression," Human Rights Quarterly 30 (2008): 849.
} 
journalism that can be critical, supportive, or inspirational. They are a form of art, an example of humour, and a means of making a social statement." 56

The internee artwork, shown throughout this chapter, was itself making social statements as critical lenses of the internment experience. In places where the barbed wire fences limited their motion and ability to feel human, this creative expression was an instance of regained autonomy for the Jewish internees. Depicting scenes beyond the internment camps (Figures 1.8 and1.9) brought the feminine to the internment camps. Paintings were a form of producing and expression of grief. Take the paintings depicting the journey to internment as an example (Figures 1.1 and 1.2). Through artistic expression the internee who painted these illustrations was able to produce an image of resistance. While they could not physically resist being taken into the hands of the earlier Nazi soldiers and later Allied soldiers, they found an avenue to critique their treatment and process to internment. The caricature of the internee Figure 1.3 gawking at the voluptuous woman walking by plays on the complicated nature of the internee as an undesirable and the male fantasies within the camp environment. As recognition of the complicated nature of their identity or an expression of political critique, internee artwork served to enrich and muddy our understanding of internment history.

This chapter looked to creative expression to understand the various methods of expression of grief and sorrow within internment situations. It explored the ways in which artwork can transcend barriers where motion is prohibited and represent a method of protest. An important aspect of this chapter was the ability for creativity to

\footnotetext{
${ }^{56}$ Hugh A. Dempsey, "A Century of Alberta Political Cartoons," Alberta History 53, no. 2 (2008): 2-3.
} 
foster an internment community. However, community looks different in different periods of this history. As we will see in the Chapter Two, the construction and importance of community was not limited to the internment camp. It, too, crossed the barbed wire and remained an important thread of the Jewish internees as they transitioned into their lives after internment. 


\section{Chapter Two: The Community Plot: Mapping Social Networks}

In the years after their release in 1942, the Jewish internees maintained contact with small networks of ex-internees. The connections between these groups make up part of a larger internment network. While Jewish internees forged face-to-face social relationships and community within the camps, after their release the configuration of "community" changed. As this chapter argues, the ways in which community manifested was different from the internment community as they were no longer bound together geographically.

There is a rich literature surrounding the idea of community and historical research. ${ }^{1}$ During their stay in the camps, internee communities featured the kinds of social relationships that Max Weber defined as communal, where the "orientation of social action...is based on a subjective feeling of the parties, whether affectual or traditional, that they belong together." ${ }^{2}$ John C. Walsh and Steven High argue that the use of social network theory helps historians to view community as a social process that changes over time, it does not assume community is rooted in a place, and recognizes communities as social constructions. ${ }^{3}$

The idea of communion and belonging present in Weber's and Walsh and High's definitions raises an important question integral to this thesis: after the internment

\footnotetext{
${ }^{1}$ John C. Walsh and Steven High, "Re-thinking the Concept of Community," Histoire Sociale /Social History 32, no. 64 (1999): 255-274. This chapter would not have been possible without the guidance and support from Dr. Shawn Graham.

${ }^{2}$ Max Weber and Talcott Parsons, The Theory of Social and Economic Organization (New York: Free Press, 1947), 136.

${ }^{3}$ Walsh and High, "Rethinking the Concept of Community," 261-262.
} 
experience what factors kept the internees in contact with each other? Digital social network analysis of a rich collection of correspondence and writing produced after internment allows us to identify a social network that featured several sub-communities clustered around key individuals and organizations. Once those sub-communities are identified, it then becomes possible to do a more qualitative reading of the same archives of letters and writing to explore the divergent and sometimes conflicting memories. These sources and this method of reading them also allows new questions to be asked about the importance and the role of certain members of these communities.

Communities are complex; often viewed from outside as homogenous, they are more aptly described as a network of smaller groups that share identification, yet can also be in conflict. Thomas Bender rejects Weber's idea of community as the "antithesis of conflict," and recognizes that the absence of conflict is not an essential characteristic of community. ${ }^{4}$ In the case of the Jewish internees, despite substantial evidence found in letters from ex-internees to Eric Koch that document similar experiences and memories of internment life, there are also clear differences. Within the postinternment community, both conflict and cooperation exist. Rather than debating its place, the varying narratives and presence of conflict allow for better understanding of the connections and identity within the ex-internee network.

Consider, for example, this case of a particularly tense exchange in the letters. Found within the correspondence between Eric Koch and ex-internees is a letter of disapproval of Koch's memoir of internment, Deemed Suspect, from ex-internee Hans

\footnotetext{
${ }^{4}$ Thomas Bender, Community and Social Change in America (New Brunswick, NJ: Rutgers University Press, 1978), 8.
} 
Reichenfeld. ${ }^{5}$ Reichenfeld questions Koch's motivation behind Deemed Suspect and critiques Koch for not having a more balanced approach in terms of the personal accounts shared. Reichenfeld admits, "strange though it may seem, my experiences as an interned 'enemy alien' had left a warm feeling in me for the country and its people." ${ }^{6}$ Arguing that Koch was portraying the internment experience as too negative, he writes that Koch's memoir adds little of value to an understanding of the political situation during their internment and offers his own experience as a counter narrative.

While this is the most extreme point of contention in the entirety of Koch's correspondence, it is important to note that it remains archived amongst the more positive responses to his letters and published memoirs. ${ }^{7}$ While the presence of conflict is significant, it does not negate the shared sense of community through memory. Reichenfeld may have remembered his experience as an interned 'enemy alien' differently than Koch and taken offense to some of Koch's recollections. However, they both remain part of the same "community of remembrance". This point of contention is a factor that held Reichenfeld part of the community he felt misrepresented his experience of internment. Considering Bender and Weber's arguments, the absence of conflict is not a compulsory characteristic of community, it is a point of departure to new questions and discussion relating to the composition of communities.

The original rationalization for this community of Jewish internees, grounded in

\footnotetext{
${ }^{5}$ Eric Koch, Deemed Suspect (Toronto: Metheun, 1980).

${ }^{6}$ Hans Reichenfeld to Eric Koch, Correspondence between Eric Koch and other internees while he collected material for his book on the internment experience, 1979-1980: R-Z, Eric Koch fonds, Library and Archives Canada (LAC), MG 30 C-192 Vol. 1.

${ }^{7}$ Some internees expressed confusion as to why Koch would want to memorialize their stay in Canada. However, Reichenfeld is the only ex-internee who disagreed with Koch's memoir.
} 
the various internment camps, was based on a shared national and ethno-religious identity. It is important to look to the social relationships post-internment and the factors beyond place that pulled these internees back to their initial bond: the internment camp. In discussing community and social network theory, John C. Walsh and Steven High call historians to view place "as the assembly of various social spaces produced by social processes such as community and economy." ${ }^{8}$ They argue social network theory helps historians to view community as a social process that changes over time, it does not assume community is rooted in a place, and recognizes communities as social constructions. ${ }^{9}$ Social network theory forces historians to view "community as a social process predicated on relationships, and therefore susceptible to change over time. Indeed, social network theory encompasses the movement of individuals into and out of the process of community." ${ }^{10}$ This research aims to understand the social processes that create these communities. By applying social network theory, the post-internment community becomes a fluid entity that is reinforced by both the materials created by internees to remember their experience and outside influences post-internment, which maintained their connections after they were released into Canada. This research argues the internment community is not solely confined to the geographical location of the camps themselves, or the historical period of internment. It also suggests that community be redefined based on various factors contributing to this network.

\footnotetext{
${ }^{8}$ Walsh and High, "Rethinking the Concept of Community," 266.

${ }^{9}$ Walsh and High, "Rethinking the Concept of Community," 261-262.

${ }^{10}$ Walsh and High, "Rethinking the Concept of Community," 261-262.
} 


\section{Social Network Analysis}

The creation of art, poems, songs, and plays in the various internment camps was an attempt to form cohesion amongst the Jewish refugees. These artifacts were preserved in archives across Canada years after. Additionally, several memoirs, accounts, and biographies were published, including Eric Koch's Deemed Suspect, which attempted to make the internment experience both public and tangible. ${ }^{11}$ In Deemed Suspect a list of "Who's Who" is found at the back of the book spanning eight pages of information on the ex-internees. ${ }^{12}$ This list is compiled with the information found in the letters that make up the network in question. Decades after Deemed Suspect was published, Helmut Kallmann began working on the Ex-Internees Newsletter, which will be unpacked in the next chapter. Six official newsletters were published between September 1996 and May 2000.13 Like Koch, Kallmann requested information from any and all ex-internees regarding their experience and what has happened in their lives since internment. They both documented the whereabouts of the internees, their accomplishments, anniversaries, and deaths. They are attempts to preserve the memories of the camp and uphold the existing ex-internee network. Combined, these are expressions of a desired "community of remembrance."

In order to map this "community of remembrance," digital tools are employed to perform social network analysis (SNA). SNA provides a visual representation of

\footnotetext{
${ }^{11}$ Walter W. Igersheimer, Blatant Injustice: The Story of a Jewish Refugee from Nazi Germany Imprisoned in Britain and Canada during World War II (Montreal \& Kingston: McGill-Queen's University Press, 2005); Eric Koch. Deemed Suspect: A Wartime Blunder (Toronto: Metheun, 1980); Erwin Schild The Very Narrow Bridge: A Memoir of an Uncertain Passage (Canada: Adath Israel Congregation/Malcolm Lester, 2001). 12 Koch, Deemed Suspect, 264-272.

13 Helmut Kallmann, Ex-Internees Newsletters, September 1996-May 2000, Hans Reiche fonds, Ottawa Jewish Archives (OJA).
} 
community that the historian would struggle to otherwise envision through more traditional readings. As Jeremy Boissevain argues,

Network analysis asks questions about who is linked to whom, the content of the linkages, the pattern they form, the relation between the pattern and behavior, and the relation between the pattern and other social factors. ${ }^{14}$

Martin Duering defines Social Network Analysis as a cross-disciplinary field of research based on the notion that the study of relations between humans can help answer research questions in various fields of study..$^{15} \mathrm{He}$ puts this concept to practice in his case study of a Jewish family living in Germany during the Second World War to show how Jews created non-Jewish acquaintances, built trusted ties to their helpers, and a personal support network, all of which helped them survive. ${ }^{16}$ Duering combines historical research methods, sociological qualitative data modeling, and network analysis tools to explore the data. He looks at why and how Jews created these relationships to get brokers to lend them aid.

My research looks at relationships between actors who already had a point of connection: the internment experience. The analysis of the visualization of the internment community allows us to investigate further into the networks amongst the internees, by returning to the archival sources, the letters, and looking for clues into

\footnotetext{
${ }^{14}$ Jeremy Boissevain, “Network analysis: A reappraisal," Current Anthropology 20, no. 2 (June 1979): 392.

${ }^{15}$ Martin Duering, "Cheat Sheet: Social Network Analysis for Humanists," Digital Humanities LAB at CVCE powered by uni.lu, April 13, 2015. http://cvcedhlab.hypotheses.org/106.

${ }^{16}$ Martin Duering, "The dynamics of helping behavior for Jewish fugitives during World War II: The importance of brokerage. The Segal Family's Case," Online Encyclopedia of Mass Violence, March 29, 2016. http://www.sciencespo.fr/mass-violence-war-massacre-resistance/en/document/dynamicshelping-behaviour-jewish-fugitives-during-second-world-war-importance-brokerage-se.
} 
why and how these post-internment relationships continued to exist. Building on the definitions of community and social networks, and combining this with social network analysis, we are able to visualize this community that is rooted in memories and shared identity.

In the years leading up to the publication of his autobiography Deemed Suspect: A Wartime Blunder in 1980, Eric Koch sent out a request for information from the exinternees he knew. There are hundreds of letters written in response. The letters are dated anywhere from 1979 until 1981, a year after publication. What is striking is the sheer enthusiasm from almost everyone at the news of Koch memorializing the Jewish experience of internment in Canada. Koch asks the internees a number of questions, one of which provides insight into the existence of a post-internment network: "Could you let me know the names and addresses of all the ex-internees you know, either in Canada or abroad?"17 These letters illuminate the presence of communities that survived after the internment experience. Many ex-internees expressed their intentions of memorializing their experiences, like Koch, but never made the time. Some sent him their own personal memoirs, artifacts, paintings, poems, amongst other things as tokens of their experience. The fact that these letters were kept and put into the archives goes beyond simply remembering. Eric Koch demonstrates the eagerness to make tangible his and other Jewish refugees' experience in Canada.

\section{Terminology and Method}

Before the network graphs are analyzed some terminology concerning social

\footnotetext{
${ }^{17}$ Correspondence between Eric Koch and other internees while he collected material for his book on the internment experience, 1979-1980, Eric Koch fonds, LAC, MG 30 C-192, Vol. 1.
} 
network analysis will be explained. The following definitions have been gathered based on Scott B. Weingart and Martin Duering's respective work:

Table 2.1 SNA Terms and Definitions

\begin{tabular}{|l|l|}
\hline Term & Definition \\
\hline Nodes & $\begin{array}{l}\text { Individual actor in the network } \\
\text { What connects two nodes (denotes a } \\
\text { relationship) }\end{array}$ \\
\hline Centrality & $\begin{array}{l}\text { Describes the extent to which a node is } \\
\text { connected to others in a network. In } \\
\text { some cases referred to as betweenness } \\
\text { centrality. }\end{array}$ \\
\hline Community & $\begin{array}{l}\text { A set of nodes which are relatively more } \\
\text { connected to each other than to the rest } \\
\text { of the graph. }\end{array}$ \\
\hline
\end{tabular}

The data gathered was derived from the internee "network," described in each ex-internee letter sent to Eric Koch. Eric Koch himself is not included in the network. It is already known that he is connected to every ex-internee and the results would produce an ego network with Koch at the center. ${ }^{19}$ Some wrote the addresses and professions of those they remained in contact with, others simply left a name. If an internee mentioned a fellow internee they remembered from camp, but did not remain in contact with them post-internment, it was not added to their list of connections. Only internees mentioned in response to Koch's question were documented. ${ }^{20}$

\footnotetext{
${ }^{18}$ Scott B. Weingart, "Demystifying Networks, Parts I \& II," Journal of Digital Humanities 1, no. 1 (Winter 2011). http://journalofdigitalhumanities.org/1-1/demystifying-networks-by-scott-weingart/. Duering, "Cheat Sheet," 2015.

${ }^{19}$ An ego network is a network that contains one actor connected to all of the actors/nodes in the network. Duering, "Cheat Sheet," 2015.

${ }^{20}$ Koch's question was so specific and leading, and it is especially valuable for my research interests: "Could you let me know the names and addresses of all the ex-internees you know, either in Canada or abroad?" Koch's original letter is found in some of the responses from the ex-internees. M Albery to Eric
} 
Many ex-internees were referred to by various names. In many cases they changed their names themselves after internment, because of their link to Nazi Germany. For example, Eric Koch's name at birth was Adolf Koch, but he quickly changed his name to Eric to ease his post-internment life in Canada. ${ }^{21}$ To account for these differences, I used the online data-cleaning tool, OpenRefine. ${ }^{22}$ After cleaning and reconciling the data, this information was compiled into a .csv file in table format labeling "Source," (the internee responding to Koch's request) and "Target" (the internees mentioned as part of the respondent's network).

The .csv file was then imported into Gephi, an open source software for network analysis. ${ }^{23}$ It was then converted into a .graphml file in order to visualize the data. It is imported as an undirected graph of 391 nodes (ex-internees) and 444 edges (connections). The visualization of the network of internees is presented as a directed graph (digraph for short). Each tie has an arrow pointing from $A$ to $B$, but it does not assume this relationship is reciprocal. ${ }^{24}$ For example, if ex-internee $A$ claims to have a relationship with ex-internee $B$, it is not assumed that ex-internee $B$ will say the same for ex-internee A. When visualized with no alterations, the .graphml file appears as it does below (see Figure 2.1). Note that the node position in this graph is random.

\footnotetext{
Koch, Correspondence between Eric Koch and other internees while he collected material for his book on the internment experience, 1979-1980: A-F, Eric Koch fonds, LAC, MG 30 C-192, Vol. 1.

${ }^{21}$ Koch, Deemed Suspect, 150.

22 “Open Refine: A free, open source, powerful tool for working with messy data," http://openrefine.org/.

23 "Gephi: The Open Graph Viz Platform," version 0.9.1, http://gephi.github.io/.

${ }^{24}$ Jeroen Bruggeman, Social Networks: An Introduction (Routledge, New York: 2008), 8.
} 


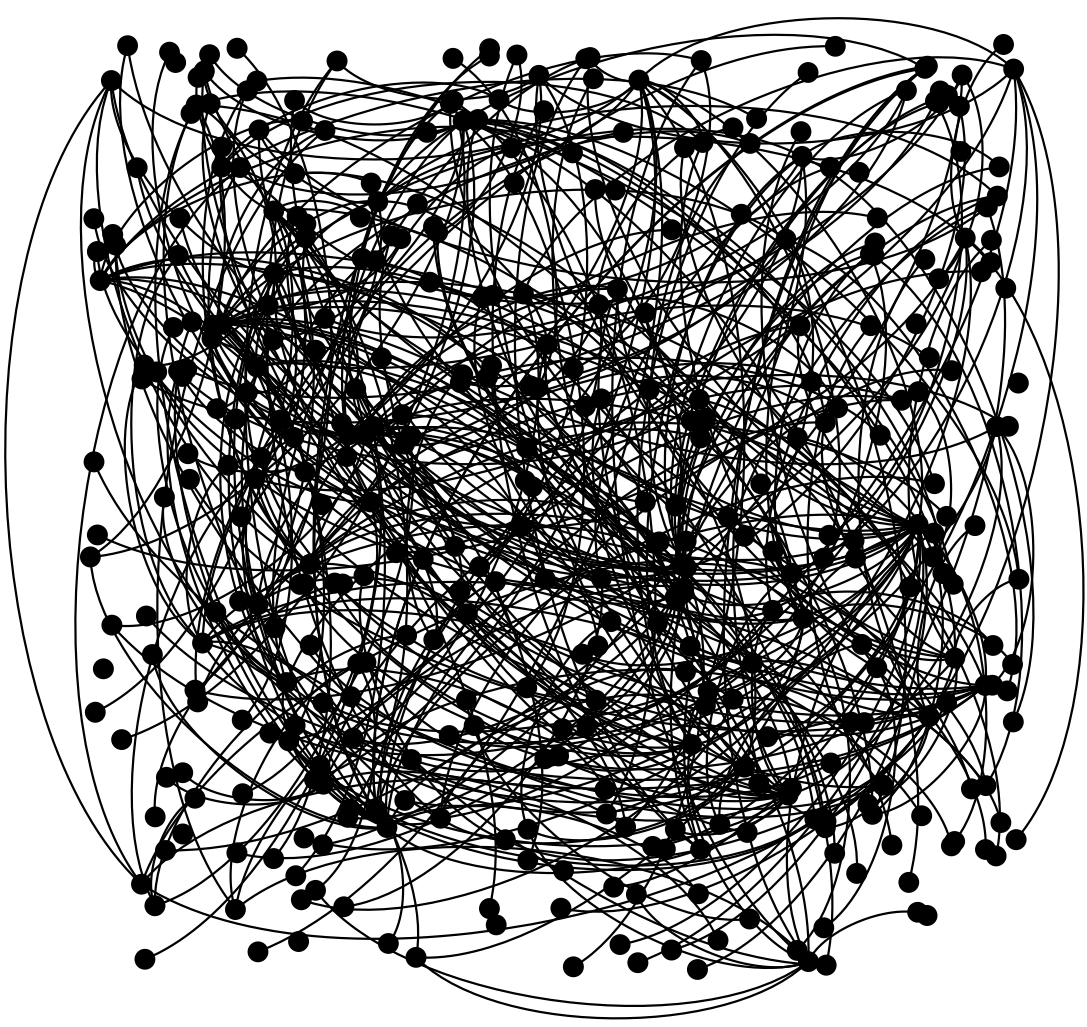

Figure 2.1 Graph with Outliers Based on Correspondence with Koch. ${ }^{25}$

\footnotetext{
${ }^{25}$ This visualization and all subsequent graphs are all based on data collected from the correspondence in Eric Koch's fonds. The data and illustrations can be found online at https://github.com/elisebigley/ExInternee-Network-Data. Initial data based on the correspondence is in the folder "Network Tables \& Data." All visualizations found in this chapter are in the folder "Network Visualizations." It is recommended to have this webpage open while reading the chapter. Some of the images are hard to see in the smaller format in this document. All of the graphs found online are in .pdf format, to allow the viewer to zoom in to certain sections of the graph and view labels (ex-internee names) clearly. There are
} 
No information about the network can be derived from this initial visualization, except that a network of some kind exists. What is important to consider when looking at later visualizations that highlight certain aspects of the community using the same data, is that this initial graph carries the same information as later graphs. The subsequent graphs are used to demonstrate certain aspects of the graph that contributes to the analysis and to present the data in an understandable way.

In order to change the shape of the graph I applied different layouts in Gephi. I chose to use the ForceAtlas layout, which follows the "Force-based" algorithm principle that "linked nodes attract each other and non-linked nodes are pushed apart." ${ }^{26}$ Its function is to spatialize networks and allow for interpretation and readability. ${ }^{27}$ The feature, "Adjust by Sizes," was used to prevent node overlap, which will come in better use when labels are included in the network graphs. The following graph (Figure 2.2) represents the entire ex-internee network with the outliers and no labels. The outcome shows a large network with smaller communities existing outside the main cluster. While not providing much information, this visualization is useful in determining the outliers. For the purposes of this project the outliers will be deleted from the dataset, as they have no connection to the main cluster they will skew later results and analysis.

two exceptions: Figures 2.1, 2.2 \& 2.3 are in .png format. Figures $2.6 \& 2.8$ are in both .png and .pdf format and they appear quite different. The .png format is a screenshot of a small section of the larger graph so the reader can view the subcommunity easily in this document. The .pdf of these Figures (2.6 \& 2.8 ) is of the entire graph to allow the viewer to zoom in more closely on each label. The same labels are highlighted in both the .png \& .pdf formats.

${ }^{26}$ Unknown, "Tutorial Layouts," Gephi: The Open Graph Viz Platform, 5. https://gephi.org/users/tutoriallayouts/.

${ }^{27}$ Unknown, "Tutorial Layouts," Gephi, 11. https://gephi.org/users/tutorial-layouts/. 


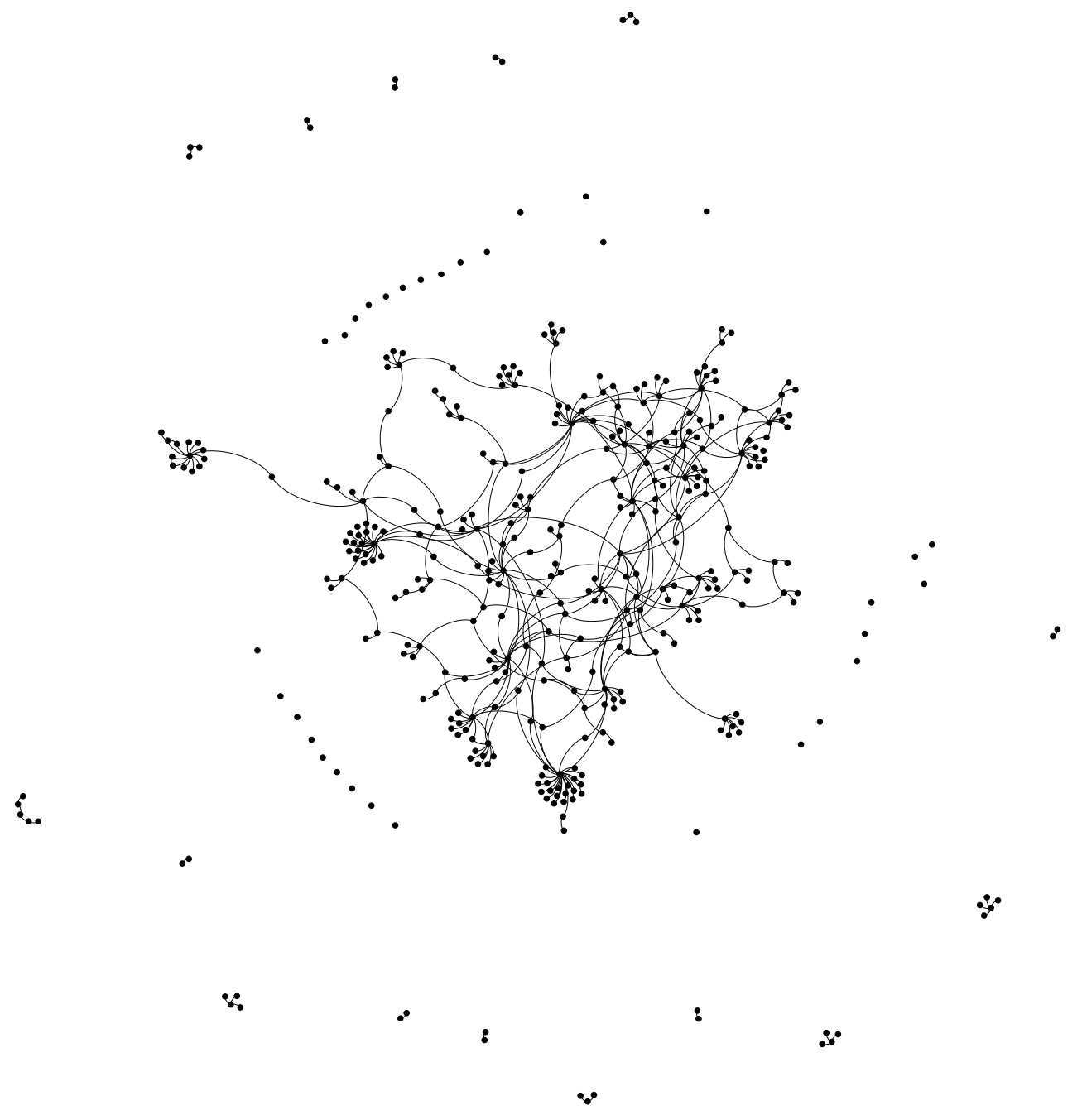

Figure 2.2 Graph with Outliers Based on Correspondence with Koch Next, the modularity was calculated to measure the strength of division of the network into modules (sub-communities). Modularity is high if the sub-communities are 
strongly pronounced and diverge from the network "by having few inter-community ties and high density within [the] communities." ${ }^{28}$ Modularity is low if the sub-communities are less pronounced and have more between-group ties. ${ }^{29}$ Thus, modularity is showing the strength and position of the sub-community itself within the larger network. Smaller communities are harder to detect when measuring modularity. In the following graph (Figure 2.3), the modularity has been calculated and each module is distinguished by colour in order to visualize the modules more easily. The outliers have been eliminated using the topology filter "Giant Component" in Gephi. There are fifty-nine different subcommunities of ex-internees in the entire network. It is clear that of these fifty-nine different groups, there are some sub-communities with high modularity in this network. For the purposes of this analysis, the modularity tool is used to better visualize the subcommunities and group each ex-internee into their module. ${ }^{30}$

\footnotetext{
28 Bruggeman, Social Networks, 40.

${ }^{29}$ Bruggeman, Social Networks, 40.

${ }^{30}$ The modularity score for this visualization is .740 on a scale from 0 to 1 . Thus, there is a strong likelihood that these groups are true.
} 


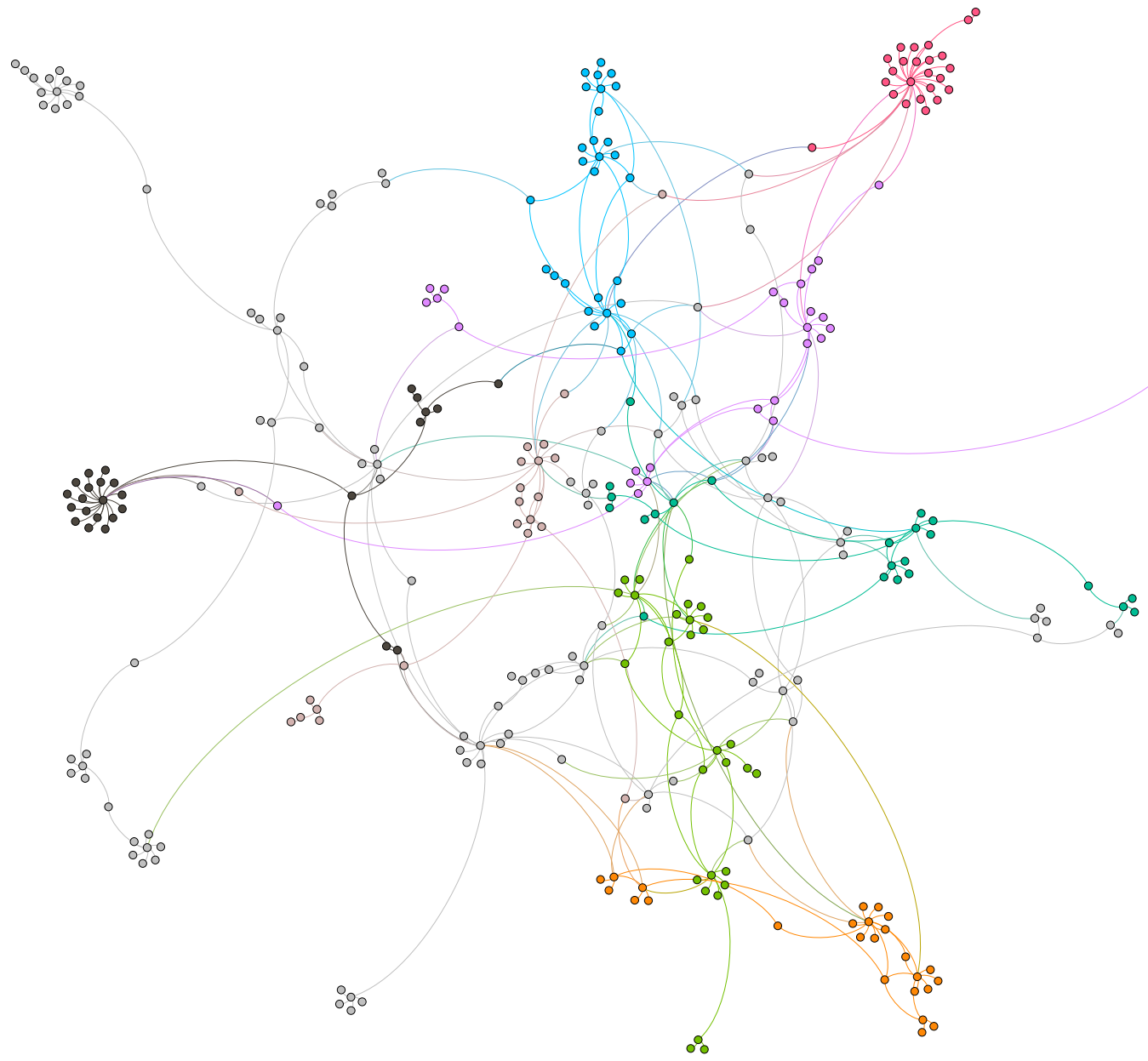

Figure 2.3 Graph with no Outliers Based on Correspondence with Koch 
By looking at the modularity and the sub-communities, and considering the archival sources that mold this network, there are a number of questions to consider in relation to how and why each individual sub-community was maintained from internment in the late twentieth century:

What beyond the barbed wire formed and maintained these subcommunities? Were these communities ones of convenience or shared interests? These questions give similar considerations to Walsh and High's discussion on social network theory and communities. What factors and relationships constitute these communities? Looking to the documents behind the graph gives insight into why each ex-internee remained part of the network, and allows for new questions to be asked surrounding each subcommunity. The aforementioned Hans Reichenfeld presents an interesting case to address the question of what beyond internment tied these internees together. Although he does not make any significant contributions in terms of holding the social network together, his reasons for being part of the community were made quite clear in his letter to Koch critical of the pessimistic way in which internment was portrayed in Deemed Suspect.

In terms of the sub-communities, an ex-internee could hold a small community together in a certain geographic location, or provide useful information or artifacts about the larger community and how it was remembered. For example, ex-internee Bernard L. Bick's community seems to have been formed based on geographic location. He lived in New Jersey and the three ex-internees he mentioned (Gerald Steinhart, Fred 
Hirschfeld, and Max Gamper) were from New York and the Bronx. ${ }^{31}$ However, he provides no information regarding their relationship and why they remained in contact.

Many of these subcommunities existed in a space beyond geography and through smaller groups and shared interests and place. Ex-internee Alvin Belitzer wrote to Koch enthusiastically about his work and listed his network of four ex-internees (Freddy Grant, Franz Kraemer, Helmut Blume, and John Newmark) to which he credited their shared interest in music for their continued connection. Freddy Grant and Franz Kraemer lived in Toronto, where Belitzer lived, while Helmut Blume and John Newmark resided in Montreal. ${ }^{32}$ While geography arguably could have played a role in maintaining the relationships, ultimately it was music that fused this group together. Other things like a shared profession kept internees in contact with each other. Within Belitzer's network, two of the ex-internees (Helmut Blume and John Newmark) had connections the Canadian Broadcasting Corporation ( $C B C)$. Helmut Blume and Eric Koch himself both worked as broadcasters for the $\mathrm{CBC}$, and the widely known pianist John Newmark after their release into Canada. ${ }^{33}$ In his 1980 interview with the CBC on being a Jewish German refugee in Canada, Eric Koch links John Newmark and Helmut Blume to the CBC as members of his post-interment network. It is important to understand some of the

\footnotetext{
${ }^{31}$ Bernard L. Bick to Erich Koch, October 1, 1979, Correspondence between Eric Koch and other internees while he collected material for his book on the internment experience, 1979-1980: A-F, Eric Koch fonds, LAC, MG 30 C-192, Vol. 1.

${ }^{32}$ Alvin Belitzer to Eric Koch, Correspondence between Eric Koch and other internees while he collected material for his book on the internment experience, 1979-1980: A-F, Eric Koch fonds, LAC, MG 30 C-192, Vol. 1.

${ }^{33}$ Helmut Blume and Eric Koch worked for the CBC on various projects as broadcasters. Musician John Newmark performed throughout his on CBC radio. Harry Brown, "Eric Koch on being a German Jewish internee in Canada in 1940," (Canada: Take 30, November 14, 1980), Television, 10:20-10:25, http://www.cbc.ca/archives/entry/eric-koch-on-being-a-german-jewish-internee-in-1940.
} 
reasons behind these subcommunities and the larger network itself. However, the strength of these modules brings light to other questions.

\section{Betweenness Centrality}

Importance and power in network theory is often linked to and associated with betweenness centrality. Betweenness centrality is used to determine the extent to which one node is connected to other nodes within a network. The tie between the two nodes is a combination of the amount of time, emotional intensity, intimacy, and reciprocal services that characterize the relationship. ${ }^{34}$ In this network, it measures who is connected to, and remained in contact with, the most ex-internees. ${ }^{35}$ The graph below (Figure 2.4) maps the main cluster of the ex-internee network using betweenness centrality determining the size of each node. Each node is labeled with the corresponding ex-internee.

\footnotetext{
34 Mark S Granovetter, "The Strength of Weak Ties," American Journal of Sociology 78, no. 6 (May 1973): 1361.

${ }^{35}$ Katharina A. Zweig, Network Analysis Literacy: A Practical Approach to the Analysis of Networks (Austria: Springer, 2016), 68-69.
} 


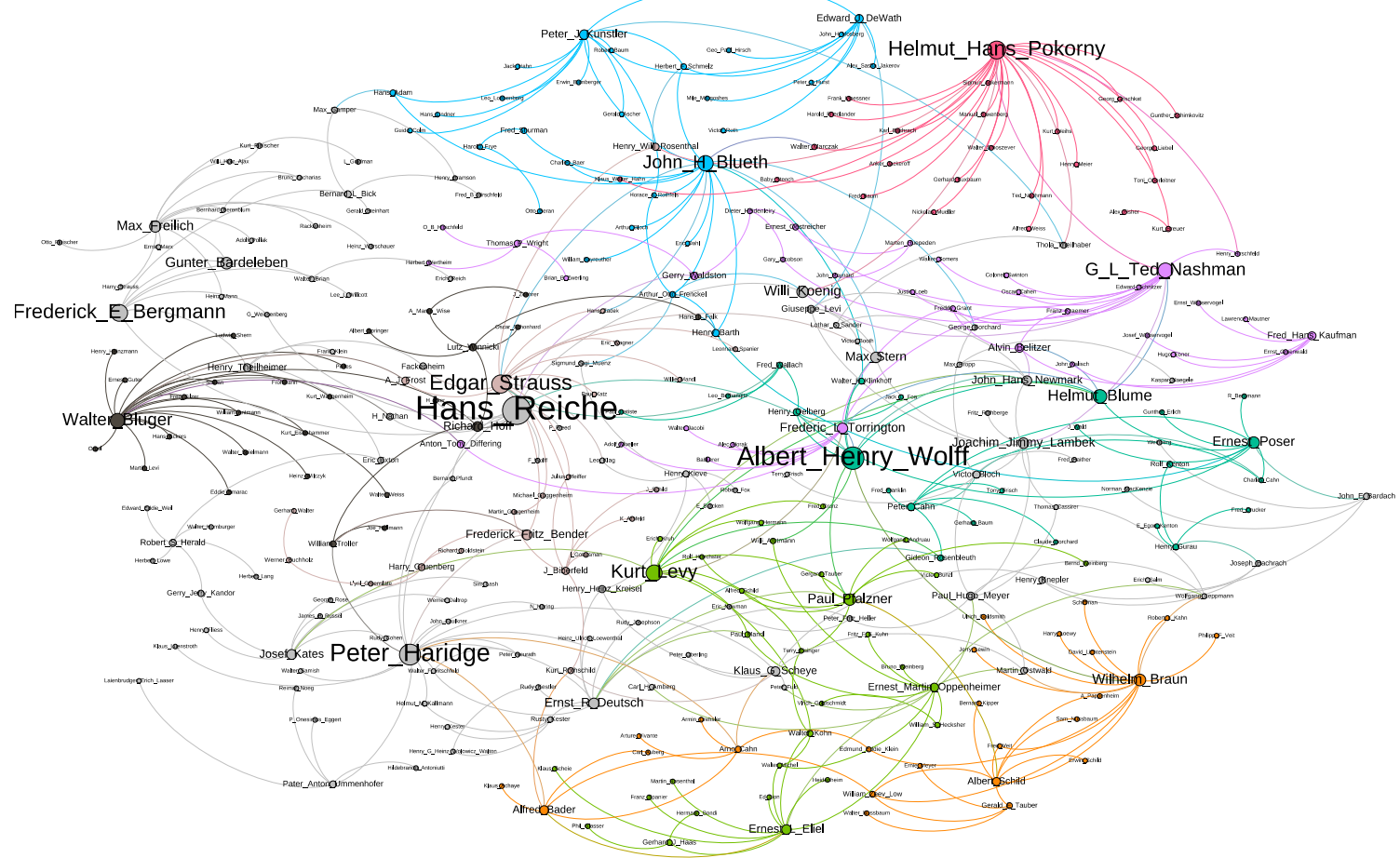

Figure 2.4. Main Cluster with Betweenness Centrality 
From observing this graph, it is clear that ex-internees like Hans Reiche, Albert Henry Wolff, Peter Haridge, and Hans Pokorny have some of the highest betweenness centrality. However, beyond this graph, the data from this network can be analyzed to determine the exact centrality of each node. Using Gephi's software the centrality was calculated with 1 as the highest centrality and 0 as the lowest centrality. Of 391 members of the network, 11 had over 0.10 betweenness centrality. These 11 members stayed in contact with the most ex-internees, and therefore maintain some of the strongest ties within the network.

Table 2.2 Ex-Internee Betweenness Centrality

\begin{tabular}{|l|l|}
\hline Ex-Internee & Betweenness Centrality \\
\hline Hans Reiche & 0.269582 \\
\hline Albert Henry Wolff & 0.20272 \\
\hline Peter Haridge & 0.184786 \\
\hline Edgar Strauss & 0.152598 \\
\hline Helmut Hans Pokorny & 0.149698 \\
\hline Frederick E Bergmann & 0.13849 \\
\hline Kurt Levy & 0.129006 \\
\hline John H Blueth & 0.122794 \\
\hline G L Ted Nashman & 0.114961 \\
\hline Walter Bluger & 0.110157 \\
\hline Helmut Blume & 0.10036 \\
\hline
\end{tabular}

There are several issues with connecting centrality to importance in social network analysis. Take Hans Pokorny as an example. When looking at the centrality using the complete network, Pokorny has one of the largest betweenness centrality of 0.149. Below is a graph of Pokorny's individual network. (Figure 2.5) 


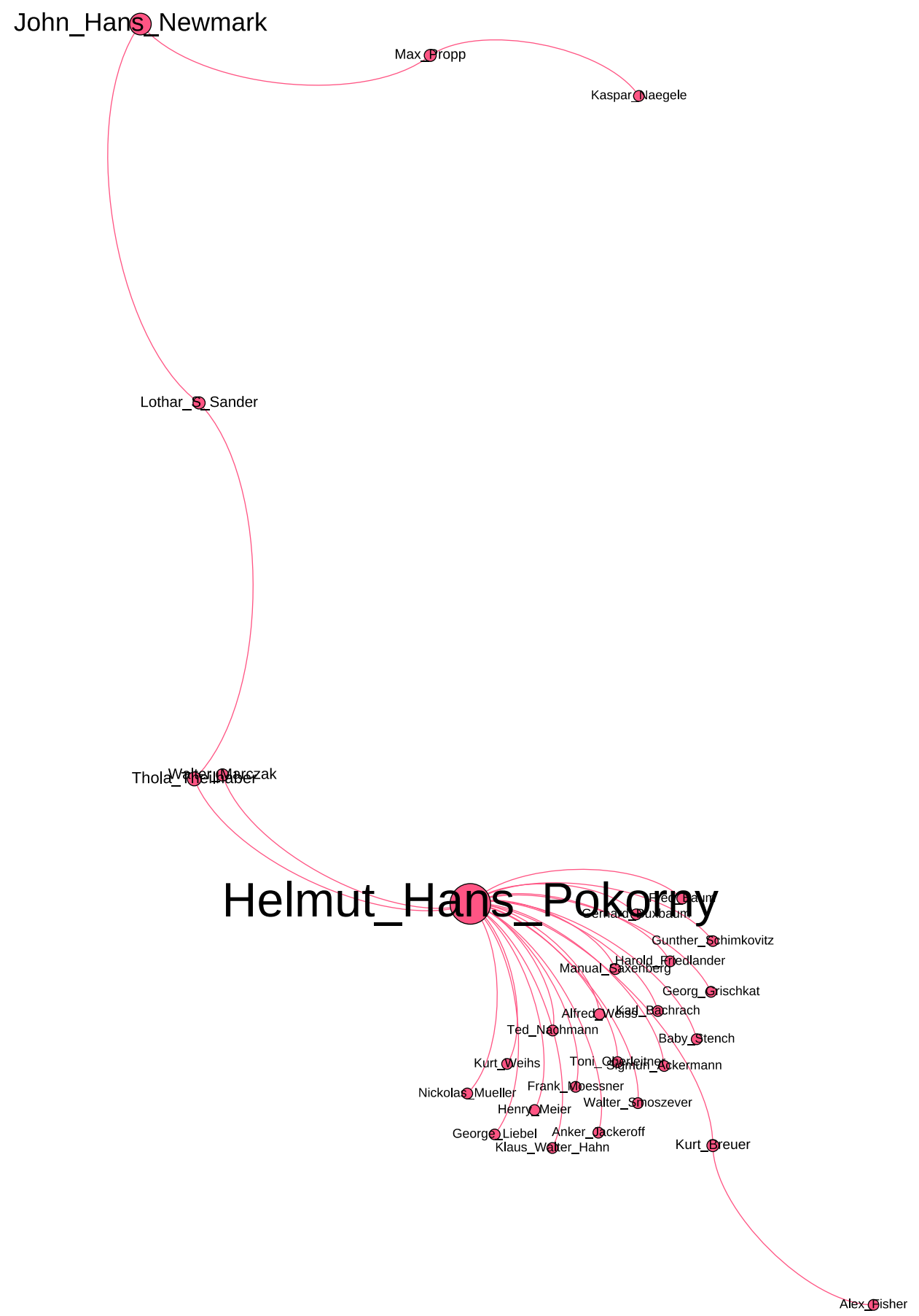

Figure 2.5 Helmut Hans Pokorny Betweenness Centrality 
What does Pokorny's strong betweenness centrality reveal? When looking at his individual network it shows a large group of nodes that are tied to Pokorny and no other nodes. This is with the exception of Kurt Breuer and Thola Theilhaber, who will be discussed later. Returning to the archival source, we find a letter from Pokorny detailing an extensive list of names, including addresses and employment information, of each ex-internee he remained in contact with. ${ }^{36}$ These names thus make up his individual network. As part of Koch's gathering of information, Pokorny is an integral component. However, as a member of the social network graph, Pokorny serves less of an important role. While betweenness centrality may illuminate certain important nodes, it is not the strength of the centrality that holds the network together.

The example of Pokorny brings light to many issues surrounding betweenness centrality and the role of each node in a graph. Albert-Laszlo Barabasi discusses the impacts of small changes within a network graph,

The construction and structure of graphs or networks is the key to understanding the complex world around us. Small changes to the topology, affecting only a few of the nodes or links, can open up hidden doors, allowing new possibilities to emerge. ${ }^{37}$

By analyzing the individual nodes and smaller subcommunities, new questions emerge. Using betweenness centrality the strength or "importance" of a node in the ex-internee network is emphasized by size.

\footnotetext{
${ }^{36}$ Hans Pokorny to Erich Koch, October 30, 1979, Correspondence between Eric Koch and other internees while he collected material for his book on the internment experience, 1979-1980: L-Q, Eric Koch fonds, LAC, MG 30 C-192, Vol. 1.

${ }^{37}$ Albert-Laszlo Barabasi, Linked: How Everything Is Connected to Everything Else and What It Means for Business, Science, and Everyday Life (New York: Basic Books, 2014), 12.
} 
Some of the "weaker" nodes in Pokorny's network are arguably more important in connecting the entire network. Mark Granovetter's 1973 work, "The Strength of Weak Ties," explores the role of nodes and links that seem less important within a network. He discusses the idea of a bridge as "a line in a network which provides the only path between two points." ${ }^{38}$ These bridges are all weak ties, while weak ties are not automatically bridges. Barabasi writes that weak ties serve as the bridge to the outside world, in using the example of acquaintances, "they obtain their information from different sources than our immediate friends." ${ }^{39}$ While not having as many connections as those nodes with higher betweenness centrality, these weaker ties are important in being a bridge to other networks. Granovetter argues, "the removal of the average weak tie would do more 'damage' to transmission probabilities than would that of the average strong one." 40 Thus for Pokorny's subcommunity, the weaker ties Kurt Breuer and Thola Theilhaber are important relationships and bridges to other ex-internees and parts of the network.

Below is a closer look at Pokorny's network with a number of ex-internees names highlighted. Kurt Breuer is a relatively small node within Pokorny's subcommunity. However, he remains Alex Fisher's only connection to Pokorny and the larger network itself. Removing him would eliminate Alex Fisher's connection with any ex-internee. Further, Thola Theilhaber is the closest link between Pokorny and Peter J Kunstler and the larger network. When measuring betweenness centrality, Theilhaber

\footnotetext{
38 Granovetter, "The Strength of Weak Ties," 1364.

39 Barabasi, Linked, 43.

${ }^{40}$ Granovetter, "The Strength of Weak Ties," 1366.
} 
may not be significant, he remains an important bridge linking Pokorny to the larger network. Thus, it is not always the amount of connections a node has that is significant, but where those connections lead in terms of the network as a whole.

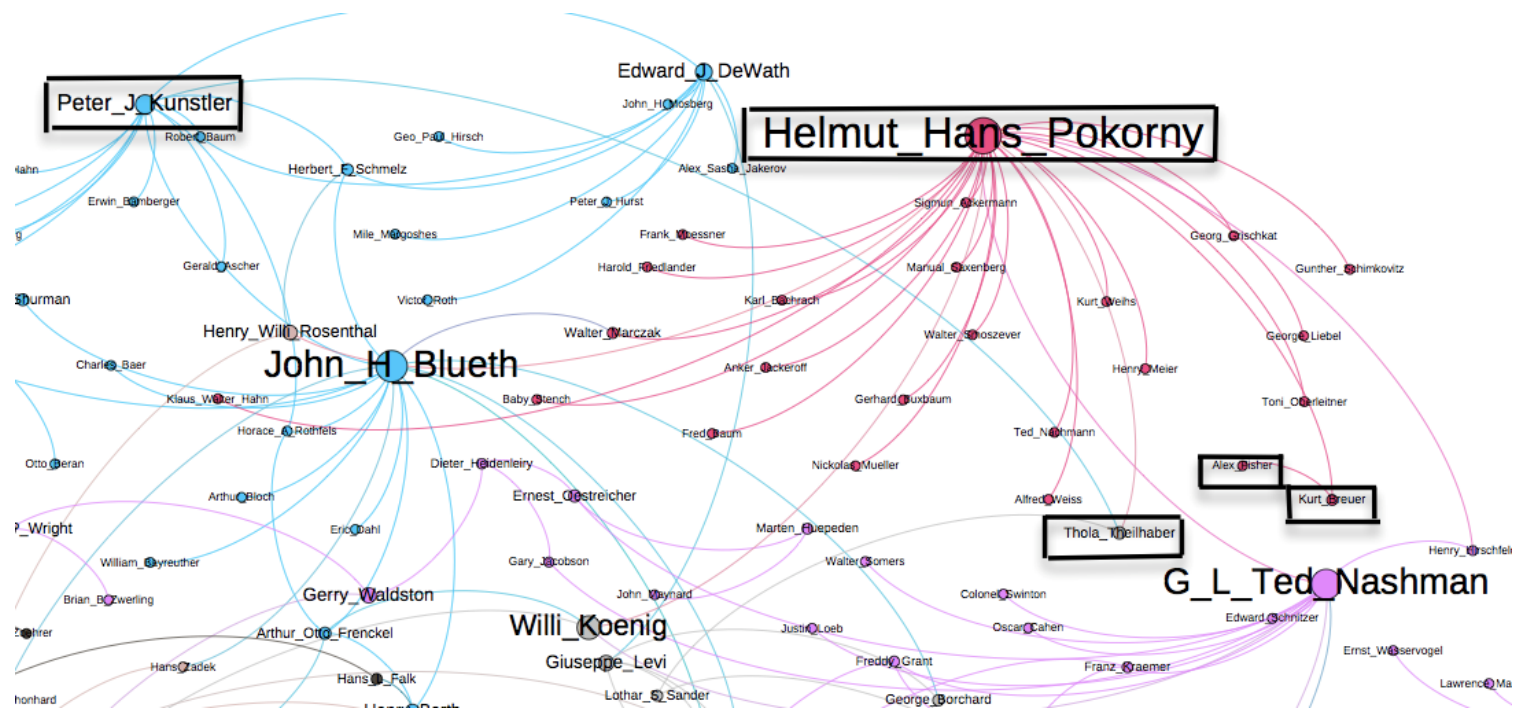

Figure 2.6 Helmut Hans Pokorny and John H Blueth bridges

Another example is Bernard L. Bick and his ex-internee connections in New York.

They are part of a module with seventeen other ex-internees. Below is a graph (Figure 2.7) of this individual module. 


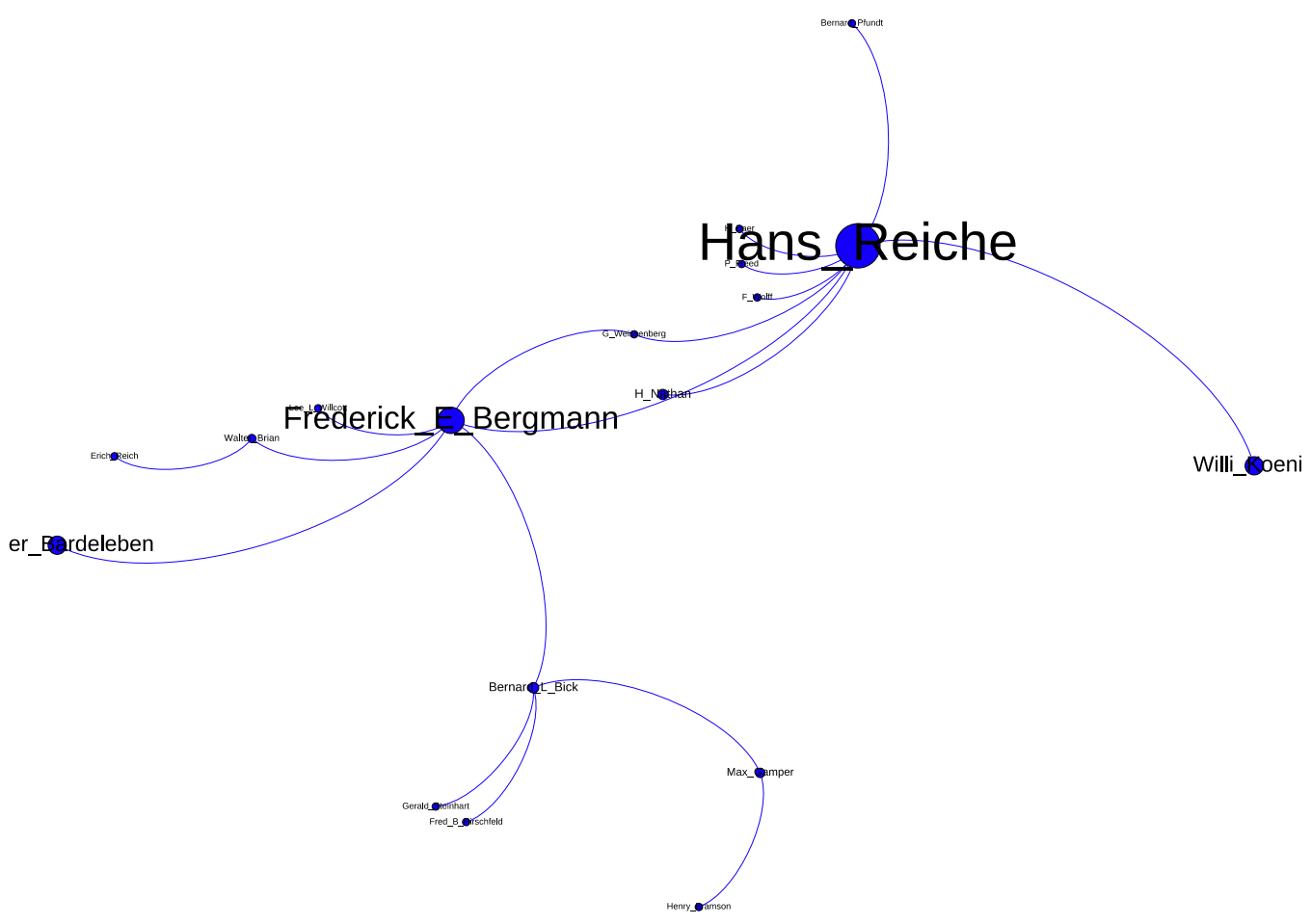

Figure 2.7 Hans Reiche Betweenness Centrality

While Hans Reiche has the highest betweenness centrality in this module (and the entire network), Bernard L Bick, and other weak ties, are important in linking four 
ex-internees to the larger network. The following graph, a closer look at Bick's community shows Max Gamper as a bridge between Bick and Henry Bramson. Max Gamper also serves an important role in connected Bick to Hans Adam and the larger community. Gamper and Bick together connect both larger subcommunities to which Frederick E Bergmann and Hans Adam belong. Similar to Hans Reiche in Bick's module, Frederick E Bergmann, while having many connections, finds Max Gamper, who only has three ex-internee connections, a crucial node in linking him to the rest of the network. An internee may be connected to many other ex-internees, however, what this shows is the quantity of connections is not as important as how well connected these exinternees were.

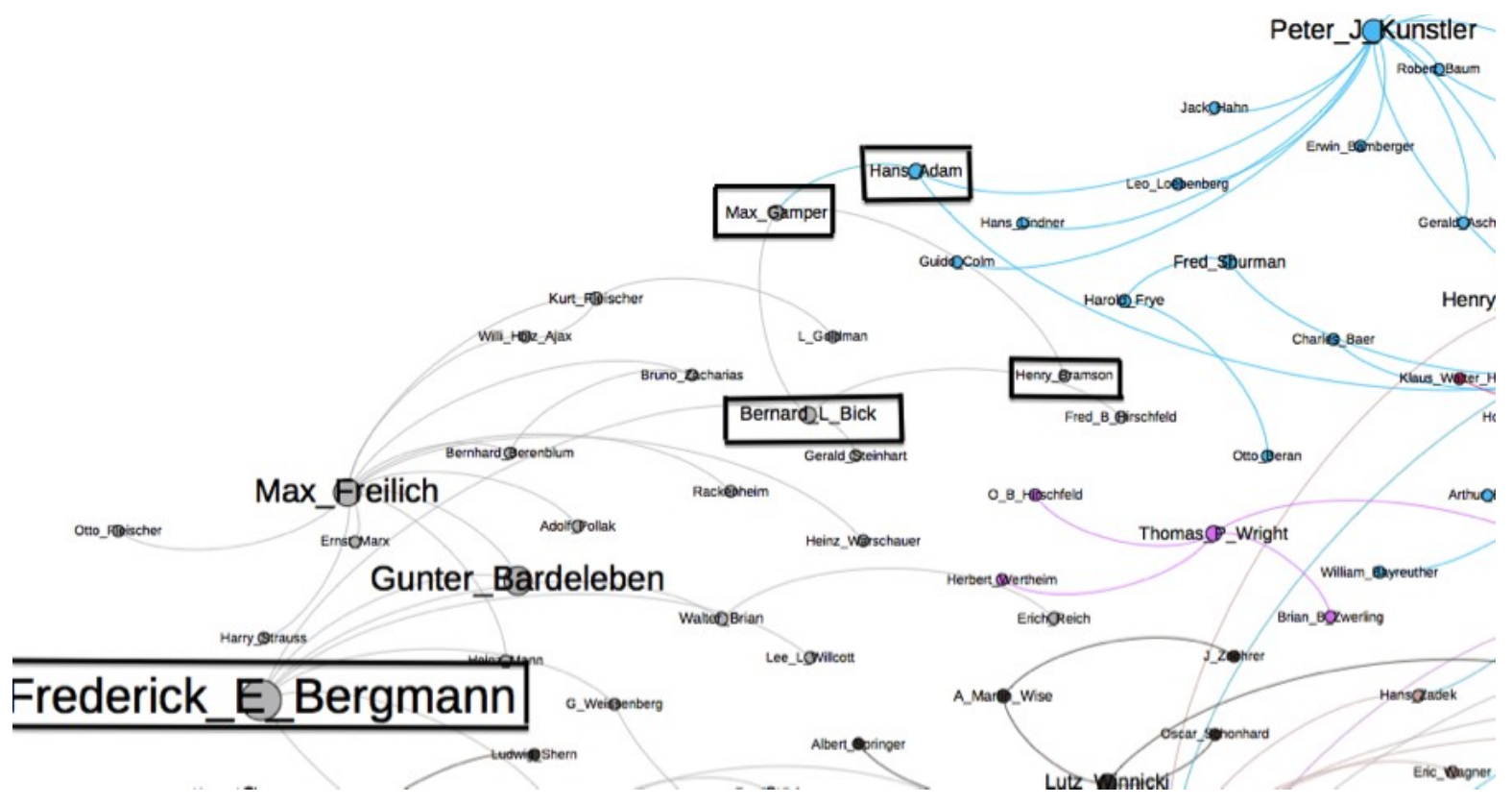

Figure 2.8 Frederick E Bergmann bridges 


\section{Community building beyond SNA}

The constructions of and connections between different groups have formed the bulk of the discussion thus far. In terms of the network, the weaker ties serve as important bridges to other networks. But what is the importance of these bridges and connections? What do the graphs not show that are important to historical discussion? The example (Figure 2.9) of Ernest Eliel provides insight into the role each ex-internee plays in the network, regardless of the strength of their connections.

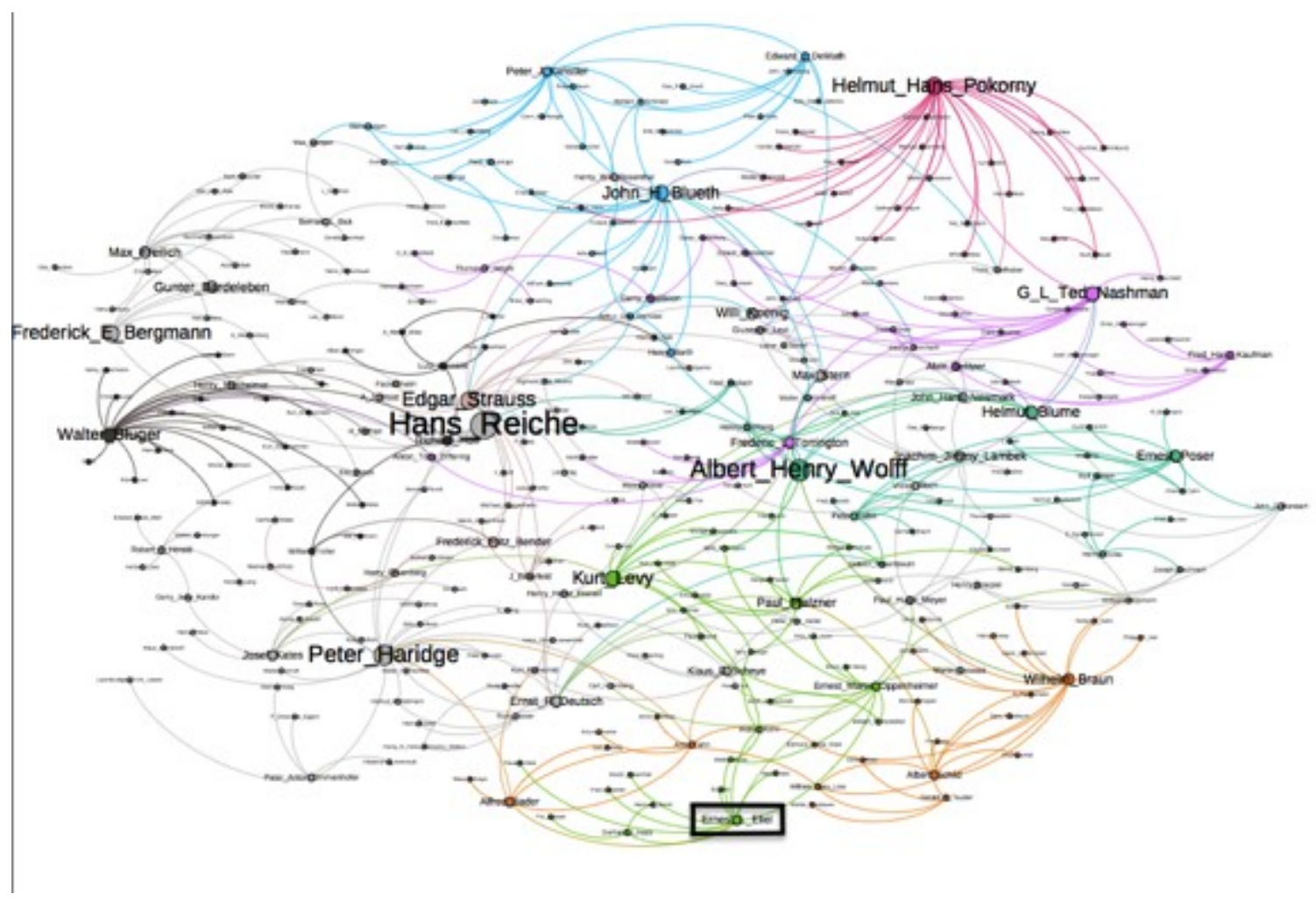

Figure 2.9 Ernest Eliel Importance in Larger Graph

Ernest Eliel ( 0.05 betweenness centrality) may not have a large network but he provides useful information to Koch and the larger community. He mentions his connection to Martin Ostwald, Klaus Scheie, and Walter Kohn. He contributes to the exinternee community in ways invisible in the visualized network. In his response to Koch, 
Eliel provides an article on ex-internee Walter Kohn, Nobel Prize-winning chemist. He enclosed government documents confirming his status as a friendly alien interned in Canada, and his change from internee status to refugee status. ${ }^{41} \mathrm{It}$ is by looking to the archives for information not captured in the visualizations that the fullness of their contributions and connections are apparent.

Another example of how a person's presence, or lack thereof, in a network does not always determine their importance in the configuration of the community is Freddy Grant. Freddy Grant was well known within the internment community as the composer of the famous song of camps Q and N, "You'll Get Used to It." 42 This song became part of the internees' shared identity, the lyrics representative of the enduring hardships of camp life. Similar to Ernest Eliel, Freddy Grant has a very low betweenness centrality and when viewed on the graph his presence is miniscule. While he may not belong to many of the ex-internees personal networks, like Eliel, Grant contributes to the community in ways other than shared connections post-internment. The case of Freddy Grant presents an interesting discussion of the limits of community analysis through social network analysis tools, and the role the archives plays in filling those voids. On the graph (Figure 2.10) he does not appear important, but in the internees' memories, Grant's song is a crucial link to their days in internment and the ways in which it is remembered by them.

\footnotetext{
${ }^{41}$ Ernest Eliel to Eric Koch, Correspondence between Eric Koch and other internees while he collected material for his book on the internment experience, 1979-1980: A-F, Eric Koch fonds, LAC, MG 30 C-192, Vol. 1.

${ }^{42}$ Freddy Grant, "You'll Get Used To It," Behind Barbed Wire, Scrapbook, LAC, MG 30 C-192, Vol. 2.
} 


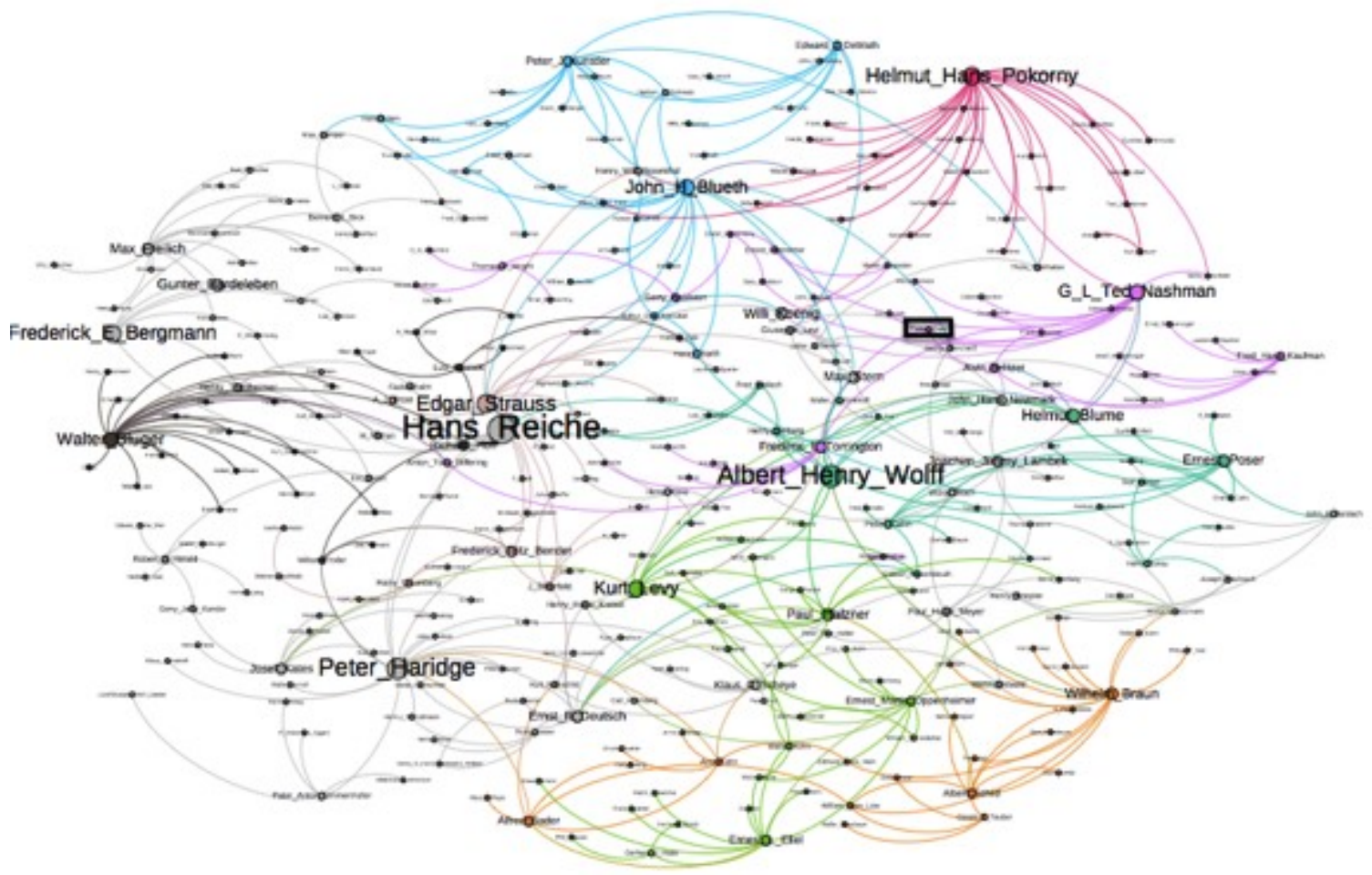

Figure 2.10 Freddy Grant Importance in Larger Graph

\section{Conclusion}

Understanding community building and maintenance through social network analysis allows for ways to find larger trends in these processes within a historical context. It provides a method to understand the larger structure of a community. Additionally, by looking to subcommunities and modules within a network the value in each individual node can be explored and appreciated. The ex-internee network is a powerful example of the ways in which community can be present beyond geography. Social network analysis allows different questions about the ex-internee community to be asked that would not necessarily be present if the data had not been pulled from the correspondence in the archives and visualized. It makes possible the exploration of how and to what extent these ex-internees connected to this community, while providing the 
opportunity to delve back into the archives and explore new connections and questions made possible by the network visualization.

Unlike the communities formed within internment, this community of remembrance existed beyond space and place. Studying creative expression and artwork in Chapter One illustrated the depth of the emotional turmoil the internees experienced. These paintings brought a human aspect into a situation of mass incarceration and dehumanization. The importance of community was clear in internees' reflections and memoirs. By visualizing the post-internment network the depth of the community itself becomes clear. Social network analysis illustrates not only the desire and importance of community but also the very real presence of postinternment networks. By applying these different methods of historical analysis we can ask questions that would not be possible to ask in traditional methods of research. Each connection contained information on the internees, internment life, and a conversation between Koch and the ex-internee. The internment narrative can thus be viewed as a multitude of internment memoirs in conversation with each other. Chapter Three explores a third expression of community, a series of newsletters distributed to exinternees in the late 1990's. Chapter One demonstrated community as an important aspect in internment, Chapter Two visualizes the existence of a post-internment community, Chapter Three will illustrate how the network of ex-internees negotiated their past and identity within the broader Canadian narrative. 


\section{Chapter Three: Community Without Locality in Post-Internment Networks}

"Have I missed you? If so, write me with all that's new since 1942!"1

Within the Erich Koch fonds resides a conversation between Koch and another ex-internee, Helmut Kallmann. ${ }^{2}$ In a letter to Koch, Kallmann writes about an earlier meeting between the two men. Kallmann expresses his embarrassment in his "immature" descriptions of his first impressions after release. However, he writes, "everyone went through a little bit of the 'zuhause war alles besser"' (at home everything was better) in self-defence, "even when you come from Nazi Germany!"3 Those impressions were his at the time of release, and Kallmann reminded Koch that his impressions of Canada at the time of the letter, in 1979, were very different. After internment, Helmut Kallmann studied piano at the University of Toronto. He worked at the $\mathrm{CBC}$ Music Library where he was a major contributor to the historiography of music in Canada. He later worked at the then National Library of Canada (now Library and Archives Canada) where he built and preserved the collection of musical Canadiana. ${ }^{4}$

\footnotetext{
${ }^{1}$ Helmut Kallmann, Ex-Internees Newsletter, Number 3, July 1997, Hans Reiche fonds, Ottawa Jewish Archives (OJA).

2 Helmut Kallmann to Eric Koch, 22 January 1979, "Kalman, Helmut Brief notes, 1973, and part of published work entitled Berliner Originale 1958," LAC, MG 30 C-192, Vol. 1.

${ }^{3}$ Helmut Kallmann to Eric Koch, 22 January 1979, "Kalman, Helmut Brief notes, 1973, and part of published work entitled Berliner Originale 1958," LAC, MG 30 C-192, Vol. 1.

${ }^{4}$ For selected works of Helmut Kallmann see: John Beckwith and Robin Elliott, eds., Mapping Canada's Music: Selected Writings of Helmut Kallmann (Waterloo: Waterloo University Press, 2013); See also: Barclay McMillan and Elaine Keillor, “Helmut Kallmann," The Canadian Encyclopedia, December 2, 2012. http://www.thecanadianencyclopedia.ca/en/article/helmut-kallmann/.
} 
Through the years and amongst his many accomplishments, Kallmann grappled with the part of his identity linked to internment in Canada in the 1940s. In his own search for meaning, Kallmann published several issues of a post-internment newsletter, the Ex-Internees Newsletter, for those interned Jewish refugees of Nazi oppression decades earlier. This chapter analyzes these newsletters as a continuation of Koch's earlier efforts at collective memory and community making. Unlike Koch, however, Kallmann's work attempted to situate their identities as men beyond the confines of the internment period. ${ }^{5}$

\section{"Returning" to Camp}

In July 1997, Kallmann returned to the site of Camp L near Quebec City, five decades after he was released from it as an internee. He found it tucked between the historic Plains of Abraham and the Citadel. Searching for familiarity in a landscape that had otherwise changed much, Kallmann noticed the surrounding road pattern and pedestrian walk as the exact same as a former internee Harry Seidler had mapped them 57 years prior. ${ }^{6}$ There were no traces of camp buildings left. No remnants of the painful history of Jewish internment in Canada. The only other visitor he came across was a lone watering truck circling the lawn. He questioned if this had any symbolic meaning. ${ }^{7}$

\footnotetext{
${ }^{5}$ Kallmann commented that Koch's book and other work on these internees only dealt with the history of internment. He argued for a representation of what the internees had accomplished and contributed to Canadian society and abroad since their release.

${ }^{6}$ Kallmann wrote in the newsletter that he used a map that ex-internee Harry Seidler created of Camp L. The map is found in Seidler's wartime diary (which Seidler deemed as a "rather typical 16 or 17 year old's effort"). This map itself was not included in the newsletter. Maps of other camps that were featured in the Ex-Internees Newsletters will be discussed later as part of the role of visuality in contribution to the narrative of Canadian internment. Harry Seidler to Eric Koch, 2 January 1979, MG 30 C-192, Vol. 1; Kallmann, Ex-Internees Newsletter, Number 3, July 1997, 1, Hans Reiche fonds, OJA.

${ }^{7}$ Kallmann, Ex-Internees Newsletter, Number 3, July 1997, 1, Hans Reiche fonds, OJA.
} 
Nearly twenty years after Kallmann visited Camp L, I visited the site of Camp $\mathrm{N}$ in Sherbrooke Quebec. There are no plaques or signs to mark the significance of the space. It was only through a National Post article on the Jewish refugees that I came across a description of the location of Camp N. ${ }^{8}$ When the Jewish refugees arrived in 1940 the internment camp consisted of one large brick building that housed train parts. When I arrived, that building still stands only now it serves as an intercity bus storage unit, Autobus de L'Estrie. Neighbouring this site is a provincial detention centre, Talbot Prison. As I reflected on the use of the current use of space, I too questioned if this had any symbolic meaning.

Kallmann's visit and my own excursion to what was once a space of internment highlights Michel de Certeau's assertion that the life we put into the space, this embodiment, creates an invisible history. ${ }^{9}$ While physical markers of these internment camps and many others no longer exist, history still occurred in these places despite any acknowledgement of the events. Kallmann's personal history in Camp L and my knowledge as historian of Camp $\mathrm{N}$ challenges the way we viewed each site in their present role. Standing in a space that once was, we are able to interact with this "invisible history" and allow it, at least in our own personal imaginations, to become visible once again.

Pierre Nora discusses the creation of lieux de memoire (sites of memory) because of a perceived social, cultural, and political need to create archives, maintain

\footnotetext{
${ }^{8}$ Graeme Hamilton, "How Jewish 'enemy aliens' overcame a 'traumatic' stint in Canadian prison camps during the Second World War," National Post, February 7, 2014.

${ }^{9}$ Michel de Certeau, The Practice of Everyday Life (Berkeley: University of California Press, 1984), 108.
} 
anniversaries, and organize celebrations. ${ }^{10}$ Nora argues that memory is archival in that "it relies entirely on the materiality of the trace, the immediacy of the recording, the visibility of the image." 11 As the ex-internees did not have a shared geographical legacy in Canada they went through active efforts to find different methods and places to insert meaning to their history. They introduced their stories in visible ways through spaces of discourse and spaces of artistic expression.

A compelling illustration of a Jewish-Canadian lieu de memoire, in their search for meaning and uncovering their past, appears in the form of the Ex-Internees Newsletters that existed between 1996 and 2000. The newsletter is a powerful example of an attempt to archive memories of an experience that did not and still does not fit the overarching popular Canadian narrative of wartime history. The process of collecting and archiving these paintings, artefacts, photographs, stories, and accomplishments in the newsletters so many decades after interment demonstrates the desire to preserve a history and identity they did not want forgotten or abandoned after they all passed on.

Similar to the artwork found in Koch's scrapbook and the letters between Koch and other ex-internees, these newsletters provide insight into the ways in which internees interacted throughout the five decades since their release. The newsletters demonstrate connections between internees and various other actors integrated within the story of these "enemy aliens." The newsletters offered a space full of memory desperately seeking to be preserved, experiences hoping to be explained and understood, and a history searching for meaning and place within a grander story. This

\footnotetext{
10 Pierre Nora, "Between Memory and History," Representations 26 (Spring 1989): 12.

${ }^{11}$ Nora, "Between Memory and History," 13.
} 
lieu de memoire the internees created became a place for a community that otherwise had no geographical grounding to exist.

\section{The Newsletters}

Six separate editions of the Ex-Internees Newsletter were published between September 1996 and May 2000. ${ }^{12}$ The first was sent to 65 people beginning with Kallmann's circle of friends and some those listed in the "Who's Who" compiled by Eric Koch for his book Deemed Suspect. ${ }^{13}$ Much like Koch's search for information for his earlier memoir, Kallmann was overwhelmed with responses from ex-internees who also wished to receive news on their fellow ex-internees. By the fourth newsletter the distribution list was well over 150 ex-internees. Kallmann provided the 'distribution list' of all the ex-internees receiving the newsletter near the end of each newsletter for other ex-internees to see. In a similar fashion, John C. Walsh in his analysis of reunions and homecomings in the Ottawa Valley, discussed the ways in which newspapers listing those who 'came home' to the reunions contributed to the boundary-work of these local communities. It allowed the people who left to reengage with what he calls the town's "us." ${ }^{14}$ While these internees were not returning 'home' to a particular location, listing the names of those who received the newsletter completed a similar task of boundary work in the post-internment community. The purpose of publishing the exinternees who were receiving the newsletter served to outline who was part of this community.

\footnotetext{
12 Helmut Kallmann, Ex-Internees Newsletters, September 1996-May 2000, Hans Reiche fonds, OJA. ${ }^{13}$ Helmut Kallmann, Ex-Internees Newsletter, Number 2, February 1997, Hans Reiche fonds, OJA. 14 John C. Walsh, "Performing Public Memory and Re-Placing Home in the Ottawa Valley, 1900-58," in Placing Memory and Remembering Place in Canada, eds. James Opp and John C. Walsh (Vancouver: UBC Press, 2010), 33.
} 
Each newsletter began with a word of greeting from Kallmann. Throughout each, a taste of Kallmann's humour and play on the politics of their internment experience was present. Like many of the newsletters creating during the internment years, the language of the Ex-Internee Newsletter often alternated between German and English.

The contents of each varied based on the response from previous newsletters.

Anniversaries, birthdays, achievements, deaths, organizations, and publications were frequently listed. Kallmann often made room in each newsletter to correct mistaken information and add new achievements by individual internees. Some issues of the $E x$ Internee Newsletters included drawings of camps, photographs of internees, and documentary artefacts from internment kept by internees such as the notice to internees arriving in Camp B, near Fredericton in August 1940. ${ }^{15}$

\section{The First Newsletter}

From the beginning of the newsletters in 1996, Kallmann was clear about his desire for a renewed connection amongst the internees as a method to document the achievements of the group. In his greetings to the ex-internees, Kallmann writes,

The news about old friends and assorted characters keep happening in by newspaper, word of mouth or publishers' advertisements. Should I keep them just to myself? Or share them with those who might be interested? ${ }^{16}$

He carries on listing the few publications and videos that have contributed to bringing some of the internees together, but only for singular events. An example is the screening of Wendy Oberlander's film Nothing to be Written Here in May 1997. Wendy

\footnotetext{
${ }^{15}$ Helmut Kallmann, Ex-Internees Newsletter, Number 3, July 1997, 10, Hans Reiche fonds, OJA.

${ }^{16}$ Helmut Kallmann, Ex-Internees Newsletter, September 1996, 1, Hans Reiche fonds, OJA.
} 
Oberlander, daughter of ex-internee Peter Oberlander, produced a film concerning her father's internment in Canada. ${ }^{17}$ Kallmann attended the screening of the film and was asked to speak on his experience of internment. In reporting this in the newsletter, Kallman also noted meeting with many ex-internees at the screening and later hosting them and Wendy at his home in Ottawa. ${ }^{18}$ He wrote that over the years, "a few friendships were renewed, but still most of us went our separate ways." ${ }^{19}$ However, Kallmann made it known that this newsletter, if successful, would serve a larger purpose than nostalgia. He argued that previous literature on their internment dealt exclusively with history of their camp experiences, and called for the study of the contributions of the "campboys" in Canada and abroad in the more than 50 years since their release from internment. ${ }^{20}$ He argued that their place in Canada was not bound to their time behind barbed wire, but continued after they were released from camp. Kallmann remained ambivalent about the importance of this newsletter and the contributions of the internees, but recognized the need to create an archive of memories and achievements that were produced after internment and not only during it. He recognizes as well that as the ex-internee community aged they must take a more active part in preserving their history for fear of it being lost. ${ }^{21}$

The language in the newsletters fosters a feeling of camaraderie and community that persevered over five decades of separation. Kallmann often addressed his readers

\footnotetext{
17 Wendy Oberlander, Nothing to be Written Here (Canada, 1996), VHS.

${ }^{18}$ Helmut Kallmann, Ex-Internees Newsletter, Number 3, July 1997, 1, Hans Reiche fonds, OJA.

${ }^{19}$ Helmut Kallmann, Ex-Internees Newsletter, September 1996, 1, Hans Reiche fonds, OJA.

${ }^{20}$ Helmut Kallmann, Ex-Internees Newsletter, September 1996, 1, Hans Reiche fonds, OJA.

${ }^{21}$ The fear and anxiety of "forgetting" in the construction of lieux de memoire is central to Pierra Nora's argument.
} 
as "fellow ex-interned refugees," "fellow-convicts," and "campboys." His greetings at the beginning of each newsletter read like a letter to an old friend. When making a case for archiving their story in these newsletters, beyond simply sharing the news, Kallmann wrote, "the youngest of us are now 72 , so perhaps the time for stocktaking is at hand." 22 Kallmann recognized that as a group they are aging and if they do not document their experience it may never be done. Another example comes from the second newsletter where Kallmann explained what the Order of Canada is to one of "our friends" in the United States who was curious as to the value of the award. ${ }^{23}$ In a previous newsletter Kallmann had listed all of the ex-internees who belonged to the Order of Canada, two of which (John Newmark and Franz Kraemer) were Officers. ${ }^{24}$

Kallmann found out from another ex-internee, Frederic Torrington, that "our brethren ex-internees in Australia also publish a newsletter and hold occasional reunions." 25 (A fourth ship of German and Austrian Jewish refugees left England in the 1940 's and docked in Australia where those men were also held in a similar situation to this group. ${ }^{26}$ ) The term "brethren" gives the perception of a link between this developing post-internment group identity to another community formed outside

\footnotetext{
22 Helmut Kallmann, Ex-Internees Newsletter, September 1996, 1, Hans Reiche fonds, OJA.

${ }^{23}$ Helmut Kallmann, Ex-Internees Newsletter, Number 2, February 1997, 2, Hans Reiche fonds, OJA.

24 Helmut Kallmann, Ex-Internees Newsletter, September 1996, 1, Hans Reiche fonds, OJA. The internees who belonged to the Order of Canada were: John Newmark, Franz Kraemer, Max Stern, Walter Homburger, Helmut Kallmann, Henry Kreisel, Gregory Baum, Fred Kaufman, and Peter Oberlander.

${ }^{25}$ Helmut Kallmann, Ex-Internees Newsletter, Number 3, July 1997, 1, Hans Reiche fonds, OJA.

${ }^{26}$ Konrad Kwiet, "'Be patient and reasonable!' The internment of German-Jewish refugees in Australia," Australian Journal of Politics \& History 31, no. 1 (April 1985): 61-77; Kay Saunders and Helen Taylor, "The Enemy Within? The Process of Interning Enemy Aliens in Queensland 1939-45," Australian Journal of Politics \& History 34, no. 1 (April 1988): 16-17; There was an exhibit on "the Dunera Boys" a group of Jewish refugees who found refuge in Australia during the Second World War. Susannah Helman, The Dunera Boys: Seventy Years On (Canberra, Australia: National Library of Australia, February 2010), https://www.nla.gov.au/media-releases/the-dunera-boys-seventy-years-on.
} 
Canadian barbed wire. It is recognition of the connection they had with their Australian counterparts who found themselves in a similar situation decades before.

In the fifth issue of the Ex-Internees Newsletter Kallmann announced an exciting event: "from our collective point of view was the award of the Nobel Prize in chemistry to our old Schicksalsagenosse Walter Kohn." ${ }^{27}$ He wrote that he received inquiries about the award asking, "is it really our Kohn?" which prompted him to publish the write up on Kohn's achievement. ${ }^{28}$ The wording conveys a sense of shared ownership and sense of identification over an individual ex-internee's contribution. Kohn and his individual journey as an ex-internee was part of their collective struggle, and thus his achievements post-internment become part of their collective achievements and sense of self worth.

The internees' pride in accomplishments is discussed in Christine Whitehouse's dissertation. In her interviews with ex-internee Gerry Waldston she comments on how he, like other former internees, boasted of the successes of many of the Jewish refugees in Canada. ${ }^{29}$ What motivated these men to mention these achievements? What drew Kallmann to list the achievements of each individual ex-internee in the newsletters? Certainly, these achievements as a form of triumph over the Nazis was a leading factor in the years after the Second World War. Perhaps the desire to demonstrate their worth and value to the Canadian government (who once saw them as dangerous "enemy

\footnotetext{
${ }^{27}$ Helmut Kallmann, Ex-Internees Newsletter, Number 5, March 1999, 1, Hans Reiche fonds, OJA. Schicksalsgenosse is a German word that translates to companion in misfortune or fellow sufferer in English.

${ }^{28}$ Helmut Kallmann, Ex-Internees Newsletter, Number 5, March 1999, 1, Hans Reiche fonds, OJA. ${ }^{29}$ Christine Whitehouse, "'You'll Get Used to It!': The Internment of Jewish Refugees in Canada 19401943" (PhD diss., Carleton University, 2016), 176.
} 
aliens") played a role in not only celebrating and documenting these successes, but also as a motivating force to be successful in the first place. These achievements also speak to a much broader discussion of Jewish masculinity. As explored in Chapter One the Jewish male has long been represented as an outsider, being anatomically different through the act of circumcision. The Jewish body has been historically seen as sexually apart. ${ }^{30}$ The combination of Germany's emergence as an imperial power, militaristic masculinity, and the trope of the effeminate Jewish man affected Jewish men's selfidentity in the first half of the twentieth century. ${ }^{31}$

In an article that investigates German Jewish masculinities as they appear in Nazi-era refugee memoirs, Judith Gerson outlines the typical masculine narratives consisting, "of selfhood filled with tales of individual accomplishments and personal demonstrations of intelligence, cleverness, and strength, resulting in notable achievements and success." 32 These newsletters dealt exclusively with the achievements of the ex-internees, with little to no mention of family life. An exception is Wendy Oberlander. But as we saw earlier, she is discussed in the context of her film screening that Kallmann and other internees attended. This focus on accomplishments in the newsletters, and also in some of the visual culture that appeared in them, reframed the internment story as a more "respectable" masculine historical narrative.

\footnotetext{
${ }^{30}$ Sander Gilman, The Jew's Body (New York: Routledge, 1991), 119.

${ }^{31}$ Benjamin Maria Baader, Sharon Gillerman, and Paul Lerner, "Introduction," in Jewish Masculinities: German Jews, Gender, and History, Benjamin Maria Baader, Sharon Gillerman, and Paul Lerner eds. (Bloomington \& Indianapolis: Indiana University Press), 2; See also Sander Gilman, The Jew's Body (New York: Routledge, 1991).

32 Judith Gerson, "Family Matters: German Jewish Masculinities among Nazi Era Refugees," in Jewish Masculinites: German Jews, Gender, and History, Benjamin Maria Baader, Sharon Gillerman, and Paul Lerner eds. (Bloomington \& Indianapolis: Indiana University Press), 212.
} 
Walter Kohn's Nobel Prize was by no means the only impressive accomplishment listed in these newsletters. A large portion of each publication was dedicated to a listing similar to the "Who's Who" found at the back of Koch's Deemed Suspect. ${ }^{33}$ The achievements of the ex-internees are impressive and many. Alfred Bader was listed as a chemical manufacturer who donated Herstmonceux Castle in England to Queen's University. ${ }^{34}$ In the final newsletter, a photograph of Alfred and his wife Isabel Bader posing in front of Herstmonceux Castle was posted from an article in The Daily Telegraph. ${ }^{35}$ Several of the ex-internees were professors at universities throughout North America. Ernst M. Oppenheimer and Willy Amtmann both found themselves as professors at Carleton University. ${ }^{36}$ The newsletters also corrected any misinformation. Kallmann cheekily warned his readers,

don't be misled by the Globe and Mail headline 'CIBC buys Oppenheimer' for \$525-million (23 July 1997). It does not refer to our friend; EMO [Ernest M. Oppenheimer] is not for sale, he is priceless! ${ }^{37}$

Here we also see a glimpse of the camaraderie and sense of humour that pervaded the newsletters. Similar to the tone of some of the artwork and newsletters created during internment, humour remained a method of expression in dealing with difficult

\footnotetext{
33 Eric Koch, Deemed Suspect: A Wartime Blunder (Toronto: Metheun, 1980), 264-272.

${ }^{34}$ Helmut Kallmann, Ex-Internees Newsletter, September 1996, 3, Hans Reiche fonds, OJA.

${ }^{35}$ Helmut Kallmann, Ex-Internees Newsletter, Number 6, May 2000, 12, Hans Reiche fonds, OJA. Again, the presence of Alfred with Isabel was not a commentary on family as it was the castle, which dominated both the image and the story told in the newsletter.

${ }^{36}$ Helmut Kallmann, Ex-Internees Newsletter, Number 2, February 1997, 5, Hans Reiche fonds, OJA; Helmut Kallmann, Ex-Internees Newsletter, September 1996, 4, Hans Reiche fonds, OJA.

${ }^{37}$ Helmut Kallmann, Ex-Internees Newsletter, Number 3, July 1997, 3, Hans Reiche fonds, OJA.
} 
circumstances. Even when reflecting on events decades before, slight mockery and satirical play on their situation was an important part of their processing. ${ }^{38}$

There is much written about this use of humour for Jews historically. Sander L Gilman discusses the reliance on humour for Holocaust survivors as a means of coping and survival. ${ }^{39}$ In survivor testimonies he recounts that humour was "a rather surprising means of keeping one's sense of control in a situation where no control was possible." 40 The use of humour also allowed survivors to look at the horrors they were experiencing from a different perspective. ${ }^{41}$ Humour was not a way to eliminate the pain they felt, but to enable them to look at their experience from a different perspective. We saw this humour and satire present in the paintings of Chapter One, especially in their expression of the internees' desires and anguish. The newsletters reflect similar notions of humour and thus allow the ex-internees to view their situation from another perspective decades after it was experienced.

\section{Space and Place}

The newsletters culminated with an ex-internees $60^{\text {th }}$ anniversary reunion in May, 2000. In the sixth newsletter Kallmann remarks,

This is Newsletter $\underline{6}$ and that digit is of special significance: It's exactly sixty years since that friendly auxiliary policeman took you away for "just a few days" with only one change of

\footnotetext{
${ }^{38}$ For humour in the Holocaust see: Sander Gilman, Jewish Frontiers: Essays on Bodies, History, and Identities (New York: Palgrave Macmillan, 2004); Steve Lipman, Laughter in Hell: The Use of Humor during the Holocaust (Northvale, NJ: J. Aronson Inc.: 1991); Chaya Ostrower, It Kept Us Alive: Humor in the Holocaust, trans. Sandy Bloom (Jerusalem: Yad Vashem, 2014).

${ }^{39}$ Sander Gilman, "Is Life Beautiful? Can the Shoah Be Funny? Some Thoughts on Recent and Older Films," Critical Inquiry 26, no. 2 (Winter 2000): 284.

${ }^{40}$ Gilman, "Is Life Beautiful?" 284.

${ }^{41}$ Chaya Ostrower, "Humor as a Defense Mechanism during the Holocaust," Interpretation: A Journal of Bible and Theology 69, no. 2 (2015): 195.
} 
underwear $\ldots$ and in July we celebrate the $60^{\text {th }}$ anniversary of our arrival in this blessed country! ${ }^{42}$

The two statements are important to note: Kallmann's playful critique of their initial imprisonment in England and his positive affirmation of Canada as a country. The description plays on the complicated nature of their history. While Kallmann noted an appreciation for Canada, he was still trying to grapple with the history that brought them there. Kallmann also advertised a second reunion of those on the Kindertransport in London in $1999 .{ }^{43}$ He mentioned the reunions of their brethren in Australia. ${ }^{44}$ These reunions served as a tool to allow internees to connect to each other, their own history, and find ways in which they "fit" into other histories. John C. Walsh explores the power of the reunion as the making of representations and of knowledge rather than a mirror of another historical reality. By doing so, the homecoming is able to draw and re-draw the boundaries of place and community. ${ }^{45}$ These internees used these reunions to also re-draw the boundaries of place and their community by 'fitting' their narrative within the Kindertransport and Australian internment story.

\section{Visuality and Accomplishments}

Photographs, maps, and artwork created in the internment camps complement the textual discourse of these newsletters. Much like the artwork in Chapter One these images are important in framing the narrative of internment. There is meaningful work on the role of visual representation as a method to solidify an experience and re-create

\footnotetext{
42 Helmut Kallmann, Ex-Internees Newsletter, Number 6, May 2000, 1, Hans Reiche fonds, OJA.

${ }^{43}$ Helmut Kallmann, Ex-Internees Newsletter, Number 2, February 1997, 9, Hans Reiche fonds, OJA.

${ }^{44}$ Helmut Kallmann, Ex-Internees Newsletter, Number 3, July 1997, 1, Hans Reiche fonds, OJA.

${ }^{45}$ Walsh, "Performing Public Memory and Re-Placing Home," 30.
} 
physical connections to places no longer there. Marianne Hirsch and Leo Spitzer examine the ways in which visual culture can aid the re-creation and physical connections to places that no longer exist. ${ }^{46}$ In their search for the physical location of their families' experiences during the Holocaust in the Transnistria area of Romania, they question whether their telling of these stories and the writing of them play a part in memorializing these events. They confess that, while they "could not hope to re-place its history into the landscape," they could make "a gesture to displace it." 47 In addition to displacing the landscape and this history, these visual depictions also illustrate much more about the ways in which internees sought to understand their history and their identity within a modern context. ${ }^{48}$

Of the artwork that was created in the internment camps, none of the sexualized or taboo subjects we saw in the paintings in Chapter One are present. The drawings instead focus on the landscape of the various camps. It shows the barracks, barbed wire, and watchtowers in the camps. The presence of life within the camps is minimal. Kallmann inserts his own drawing of Camp I alongside a floor plan (Figure 3.1) of Camp I in Montreal, Quebec. The illustration gives the perspective of the camp from the ground, offering a rather different, complementary visual perspective to the floor plan (which was copied in 1961 from an original drawing done in 1943). A selection of drawings (Figure 3.2) by Henry H. Chary depicts similar aspects of the built geography of

\footnotetext{
${ }^{46}$ Marianne Hirsch and Leo Spitzer, "There Was Never a Camp Here': Searching for Vapniarka," in Locating Memory: Photographic Acts, eds. Annette Kuhn and Kirsten Emiko McAllister (New York: Berghahn Books, 2006), 138.

${ }^{47}$ Hirsch and Spitzer, "'There Was Never a Camp Here'," 152-153.

${ }^{48}$ In this respect, I am in much agreement with Christine Whitehouse's approach to images as affecting historical evidence on their own and not merely something to be studied as in support of written sources. Whitehouse, "'You'll Get Used to It!'," 25.
} 
the camps. While such illustrations focus on the space of internment, they ignore much of the human aspects of camp such as the expression of anguish that was so prevalent amongst internment artwork in Koch's scrapbook. There are no illustrations of women or the frustrations the internees experienced in camp. However, Kallmann does insert drawings done by him of other internees sleeping or resting in camp. ${ }^{49}$

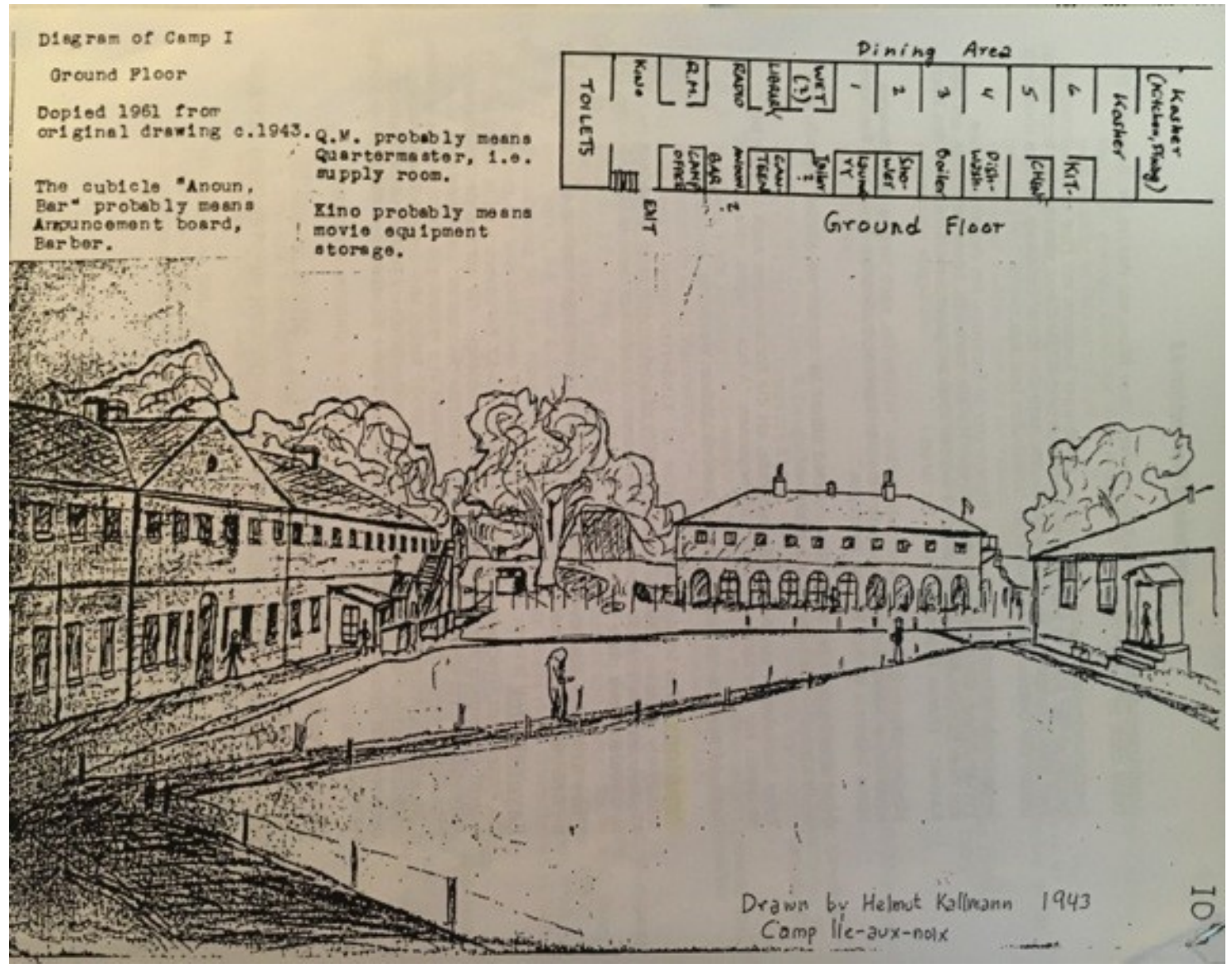

Figure 3.1 Diagram of Camp I, Helmut Kallmann, Ex-Internees Newsletter Number 3, July 1997, 10, Hans Reiche fonds, OJA.

\footnotetext{
${ }^{49}$ Helmut Kallmann, Ex-Internees Newsletter, Number 4, March 1998, 12, Hans Reiche fonds, OJA.
} 


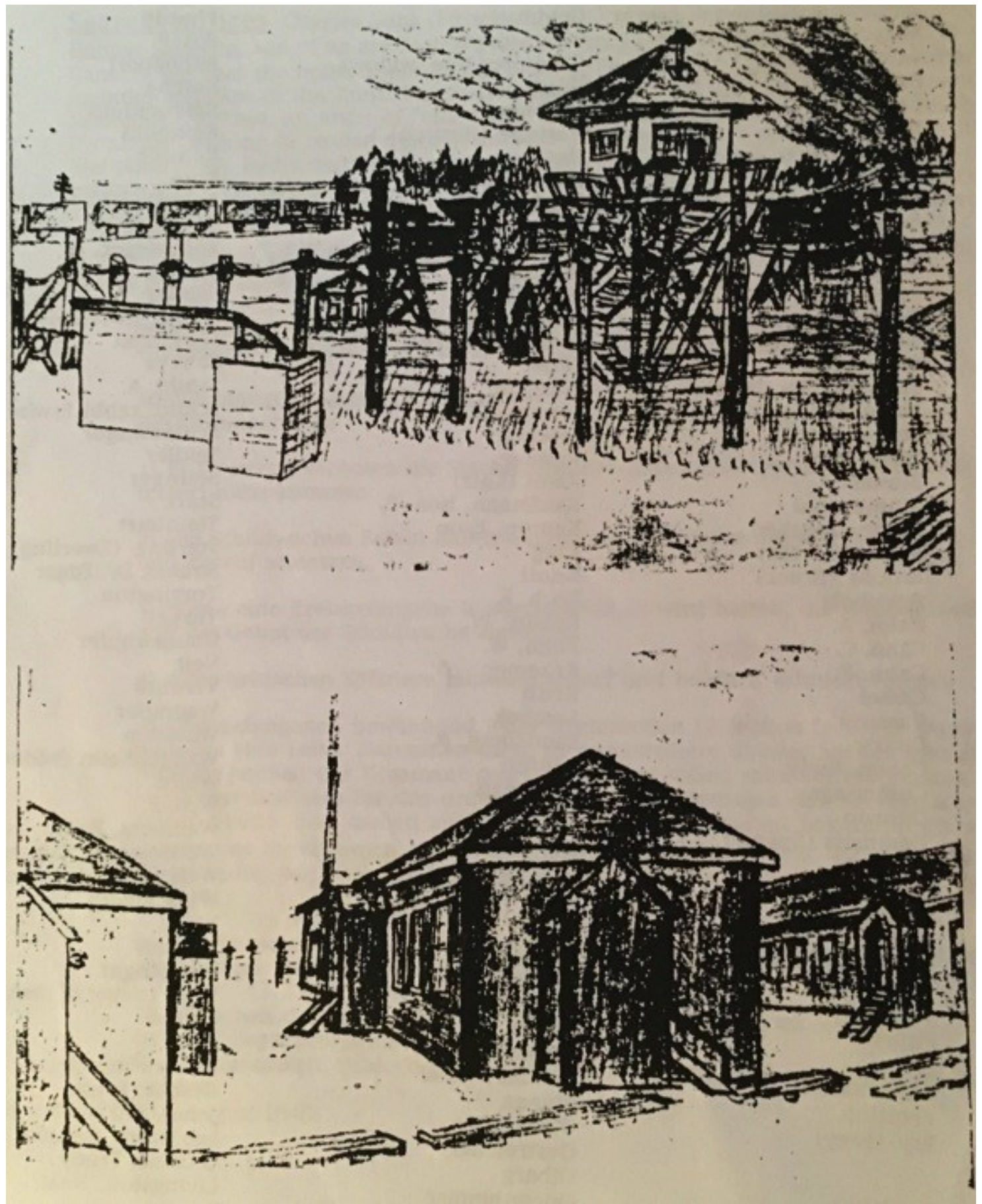

Figure 3.2 Camp Q - Drawings by Henry H. Chary 1940, Henry H. Chary, Ex-Internees Newsletter Number 3, July 1997, 12, Hans Reiche fonds, OJA.

Similar to Seidler's map that allowed Kallmann to situate himself outside of Camp L, these illustrations of the camp re-place the camps that once existed. The illustrations 
point more to a desire for situating the camps in space and recognition of their existence. They also speak to the internees' acknowledgment and memory of the space. The photographs were almost all exclusively images of the internees, groups of internees, and ex-internees throughout the decades. From photographs of matriculation school to those of small reunions in 1997, the pictures depict these men as educated, professional, and successful. Kirsten Emiko McAllister studies photographs of institutional life produced within Japanese internment camps in Canada during World War II, and she argues they displayed a normalcy in the camps but also serve to anonymize the people. The identities of those internees in the photographs were tied to an institution and no one was supposed to "stand out." 50 While this is the same in the group photographs shown in the newsletters, this idea of being tied to an institution allowed the internees to gain a sense of belonging. They were also presenting internment in a more sterilized manner than presented before in the paintings in Chapter One. Consider the following photograph (Figure 3.3) of six ex-internees.

\footnotetext{
${ }^{50}$ Kirsten Emiko McAllister, "Archive and Myth: The Changing Memoryscape of Japanese Canadian Internment Camp," in Placing Memory and Remembering Place in Canada, James Opp and John C. Walsh eds. (Vancouver: UBC Press, 2010), 230.
} 


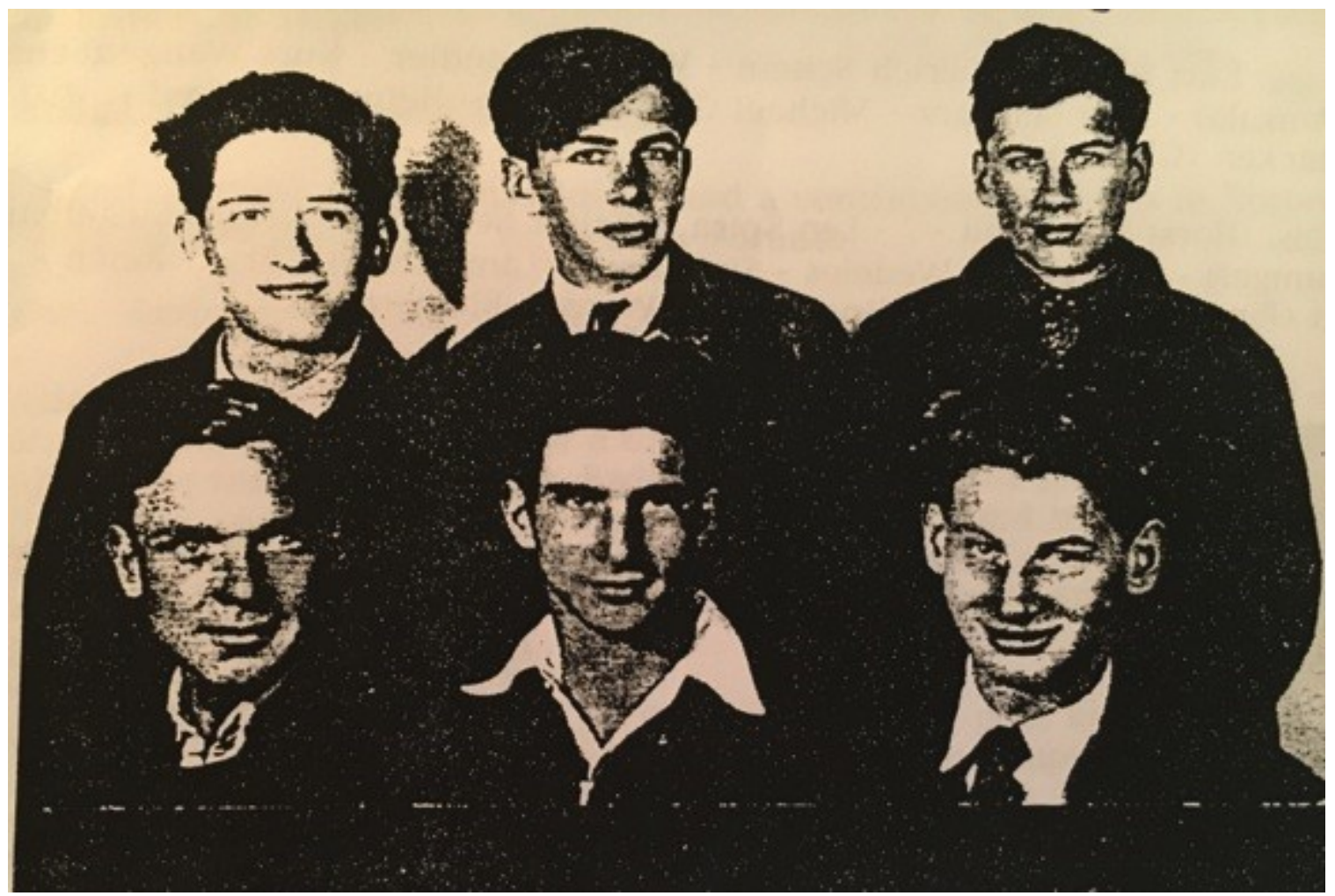

Figure 3.3 Untitled, Ex-Internees Newsletter Number 4, March 1998, 11, Hans Reiche fonds, OJA.

This photo exemplifies the "normalcy" Kirsten McAllister sees in photographs in Japanese internment camps. Ex-internee Josef Eisinger provided the photograph for the newsletter and Kallmann printed each ex-internee's name above the picture. ${ }^{51}$ Kallmann wrote that the photo was presumably taken "in the years immediately after release from camp" and added that, "five of them obtained a doctorate!"52 Kallmann not only listed the successes of the internees, but also imprinted these accomplishments on images taken decades before. McAllister argues images can take on new meaning when "they enter new choreographies that are generated by tracing their movement through

\footnotetext{
${ }^{51}$ (left to right upper row) Walter Michel - Josef (Bubi) Eisinger - Walter Kohn; (lower row) Walter Odze George Sanger - Joseph (Pepi) Weininger. Helmut Kallmann, Ex-Internees Newsletter Number 4, March 1998, 11, Hans Reiche fonds, OJA.

${ }^{52}$ Helmut Kallmann, Ex-Internees Newsletter Number 4, March 1998, 11, Hans Reiche fonds, OJA.
} 
repertoires where they are re-imagined and re-narrated in multiple ways." 53 These types of photographs, McAllister argues, "retrospectively reimage and rework the meaning of" the sites of internment. ${ }^{54}$ The photograph is no longer simply an image of six exinternees, but six ex-internees who became accomplished and well educated men. This photograph, like the newsletter as a whole, demonstrates how the internees' search for meaning is part of a larger conversation of identity and memory making. Thus, their desire to understand their role as active participants within Canadian society influenced the way these ex-internees approached the history of their internment.

\section{Nostalgia and the Longing for 'Home'}

This thesis situates itself within a rich literature on nostalgia and belonging in displaced groups. Svetlana Boym writes of nostalgia as a sentiment of loss and displacement and a longing for a home that no longer exists:

A cinematic image of nostalgia is a double exposure, or a superimposition of two images - of home and abroad, past land present, dream and everyday life. The moment we try to force it into a single image, it breaks the frame or burns the surface. ${ }^{55}$

Nadia Atia and Jeremy Davies consider the notion of nostalgia as a negotiation between continuity and discontinuity: "it insists on the bond between our present selves and a certain fragment of the past, but also on the force of our separation from what we have lost." 56 They explore the purpose of nostalgia in history and how it has been used historically. Nostalgia can be a force to complicate our understandings of the past and

\footnotetext{
53 McAllister, "Archive and Myth," 241.

54 McAllister, "Archive and Myth," 241.

55 Svetlana Boym, The Future of Nostalgia (New York: Basic Books, 2001), xiii-xiv.

${ }^{56}$ Nadia Atia and Jeremy Davies, "Nostalgia and the shapes of history," Memory Studies 3, no. 3 (2010): 184.
} 
identity, rather than simplify ${ }^{57}$ Building off of Boym, they argue nostalgia has the potential to be more mobile, active, and self-aware than previously understood. ${ }^{58}$ Nostalgia thus presents a powerful tool in considering one's past and sense of belonging.

Michele Langfield looks to Jewish Holocaust survivor testimonies to explore the models of home and belonging. Langfield writes, "identity formation is not only associated with place but even more importantly perhaps, with people, families, communities and the intangible values they share." ${ }^{59}$ In researching the migration of refugees to Australia, Peter Read writes this of home:

Home may be memories of activities, or a satisfaction of simple living, or an absence of negative emotions, or the joy of being in or cultivating a garden, of children growing up, memories of particular trees or shrubs, associations with particular people or special sites. Some of these elements are not portable because they are conceptual or intangible. ${ }^{60}$

This yearning for home does not have to be rooted in place. The Jewish refugees wrestled with home as a concept and place: their families and their homeland. What happens when "home" represents trauma, pain, and displacement? Read understands the desire for a home, "is the point where griefs for lost countries, towns, properties,

\footnotetext{
57 Atia and Davies, “Nostalgia," 181.

${ }^{58}$ Atia and Davies, "Nostalgia," 182. John C. Walsh considers nostalgia's role in the homecoming of white settler groups in small-town Ontario as collapsing time and distance of separation to a local world that existed before the settler groups left what was once their home. Walsh, "Performing Public Memory and Re-Placing Home," 33.

${ }^{59}$ Michele Langfield, “'Lost Worlds': Reflections on Home and Belonging in Jewish Holocaust Survivor Testimonies," Jewish Culture and History 9, no. 2-3 (May 2012): 46.

60 Peter Read, “Leaving Home," Journal of Australian Studies 23, no. 61 (1999): 37.
} 
gardens and suburbs seem to meet. Home is the ultimate focus of all lost places." ${ }^{61}$

Langfield writes that while home is a complicated concept when considering the Holocaust, as survivors rarely mentioned homesickness in their testimonies, while a sense of nostalgia was evident. ${ }^{62}$ The traumatic events influenced how the survivors saw their former homelands and wished never to return to Europe. ${ }^{63}$ In his work on the history of migration and the journeys back to the spaces where migrants once where, Read studies how the journey takes place either on the ground or in the mind as they return to nothing. ${ }^{64}$ The Ex-Internee Newsletters often grappled with these journeys and the challenge of considering where their history belonged. The complicated nature of home and homeland is no stranger to Jewish identity and history. ${ }^{65}$ Rebecca Kobrin's work on the diaspora and Eastern Europe challenges the notion of the identity of the Jewish diaspora as solely rooted around Zion. ${ }^{66}$ Kobrin analyzes the Bialystoker Stimme (The Voice of Bialystok), a Yiddish newspaper published in New York for the former residents of the Polish city who had immigrated decades before. ${ }^{67}$ It is through the publication of Bialystoker Stimme that illustrated their longing for their homeland and complicated the understanding of Jews longing for Zion. Similar to the Ex-Internees

\footnotetext{
${ }^{61}$ Peter Read, Returning to Nothing: The Meaning of Lost Places (Cambridge: Cambridge University Press, 1996), 102.

62 Langfield, "'Lost Worlds'," 42.

63 Langfield, "'Lost Worlds'," 43; Read, Returning to Nothing, 29.

${ }^{64}$ Read, Returning to Nothing, vii.

65 See: Robin Cohen, Global Diasporas: An Introduction (New York: Routledge, 2008); Daniel Boyarin and Johnathan Boyarin, "Diaspora: Generation and the Ground of Jewish Identity," Critical Inquiry 19, no. 4 (1993): 693-725; James Clifford, “Diasporas," Cultural Anthropology 9, no. 3 (August 1994): 302-344. Rebecca Kobrin, Jewish Bialystok and Its Diaspora (Indiana: Indiana University Press, 2010). ${ }^{66}$ Rebecca Kobrin, "Rewriting the Diaspora: Images of Eastern Europe in the Bialystok Landsmanshaft Press, 1921-45," Jewish Social Studies 12, no. 3 (Spring/Summer 2006): 4. Kobrin challenged William Safran's view of the Jewish diaspora: William Safran, "Diasporas in Modern Societies: Myths of Homeland and Return," 1, no. 1 (Spring 1991): 83-99.

${ }^{67}$ Kobrin, "Rewriting the Diaspora," 1.
} 
Newsletters, both publications offer narratives that were searching for "home" beyond the geographical sense. It is in this interaction with their past that there begins a conversation about their identity. They look to the ways in which "home" was as a foundational piece of their identity and the role it had in shaping them.

For example, one issue of the newsletter explores what Germany means to the internees now that decades have passed since their displacement to Canada. The newsletters often include write-ups in German, specific German words, and other publications in German. Kallmann asks his readers about their attitude towards the German language and visiting Germany or Austria, to which he later received a number of replies that nearly all were favourable. ${ }^{68}$ One internee wrote,

I never separated myself from my German cultural background and as the years pass...I feel more and more strongly tied to it. I am never happier than when I can speak or write German to friends. ${ }^{69}$

Kallmann visited Germany during his time as editor of the Ex-Internees Newsletter and discusses his attachment to the country and city in which he grew up. He writes that as much as he understands some of the "Berliners" attitude of never wanting to step foot back in Germany, he still felt quite at home there. He reminds his readers: "let's not forget that the Nazis were defeated and we were the winners." 70 Thus, not only was the German language incorporated into this post-internment discourse, Kallmann opened up a space for the internees to interact with what Germany as a place represented to

\footnotetext{
68 Helmut Kallmann, Ex-Internees Newsletter, Number 5, March 1999, 1, Hans Reiche fonds, OJA. ${ }^{69}$ Helmut Kallmann, Ex-Internees Newsletter, Number 5, March 1999, 1, Hans Reiche fonds, OJA. ${ }^{70}$ Helmut Kallmann, Ex-Internees Newsletter, Number 6, May 2000, 2, Hans Reiche fonds, OJA.
} 
them. As much as some may have never wanted to step foot back in Germany, it still represented a foundational piece of their story.

In his discussion on Germany, Kallmann discusses the concept of place and detachment. He writes,

I am more affected emotionally by the memory of Nazi crimes when I sit at home contemplating the past than when I actually stand in front of a specific house, street corner, school, synagogue, or church where ghastly things took place. ${ }^{71}$

Kallmann acknowledges his attachment to Germany, but his distance from it has heightened his emotional reaction to the crimes of the past. However, when he is confronted with the synagogue, house, or street that the events took place he is less disturbed. Kallmann recognized the impact of existing within a space in which the structures and markers of tragic events still remain. Peter Read also explores how the journey of returning to the spaces where migrants once lived takes place either on the ground or in the mind as they return to nothing. ${ }^{72} \mathrm{He}$ follows the story of Arnold Zable whose family came from Bialystok on the Russian-Polish border after the Second World War. ${ }^{73}$ Spending his life in Australia, Zable went to Bialystok as an adult to the places where his family once lived. ${ }^{74}$ Returning to the sites of which he had only before heard broken stories from relatives the past became real: "The chilling, but wordless past, the intense, passionate but broken narratives were made whole in the human site and field of action, that place." ${ }^{75}$ Andrew Riemer left Hungary to Australia with his family in 1947

\footnotetext{
${ }^{71}$ Helmut Kallmann, Ex-Internees Newsletter, Number 6, May 2000, 2, Hans Reiche fonds, OJA.

72 Read, Returning to Nothing, vii.

${ }^{73}$ Read, Returning to Nothing, 47.

${ }^{74}$ Read, Returning to Nothing, 48.

${ }^{75}$ Read, Returning to Nothing, 48-49.
} 
at the age of eleven. Unlike Zable, Riemer had lived in Budapest prior to immigrating to Australia, his memories few, but he felt attached nonetheless to Budapest. ${ }^{76}$ After visiting he felt he belonged emotionally neither in Budapest nor Australia. Zable, Riemer, and Kallmann, all explore the relationship between memory, place, and belonging when confronting what Read calls a dead homeland. Central to their understanding of "home" are these two questions articulated by Read: "When does 'them' become 'us', 'I' become 'we', 'these people' become 'my people?' Is there, for some, no country to which they can return - or advance?"77 As the internees examined their place in various historical narratives they too confronted similar challenges.

While many of the camps do not exist anymore in Canada there is one place that the Jewish refugees' journey is memorialized in Canada. In his first newsletter Kallmann advertised the desire of the New Brunswick Internment Camp Committee to rebuild a model of Camp B and create an educational centre for students and tourists. ${ }^{78}$ His short and humourous description ended with a question to all internees: "Anyone itching to be a tour guide? Or establish a move into a retirement home perhaps?"79 He updated the internees on the success of the museum in later years, writing that a professor Erika Leppmann of Oberlin College, Ohio thought the displays in New Brunswick as the best on any North American internment camp. ${ }^{80}$ With the wittiness consistently used in exploring the history of internment, Kallmann recognized this physical space of internment as important to the community.

\footnotetext{
${ }^{76}$ Read, Returning to Nothing, 49.

77 Read, Returning to Nothing, 51.

78 Helmut Kallmann, Ex-Internees Newsletter, September 1996, 6, Hans Reiche fonds, OJA.

${ }^{79}$ Helmut Kallmann, Ex-Internees Newsletter, September 1996, 6, Hans Reiche fonds, OJA.

${ }^{80}$ Helmut Kallmann, Ex-Internees Newsletter, Number 4, March 1998, 10, Hans Reiche fonds, OJA.
} 
In the late 1990s, Ed Caissie, a teacher in Minto, New Brunswick started the project of re-creation and development of the New Brunswick Internment Camp Museum. Originally started to involve a small group of at-risk students, eventually over 60 students from the city of Minto, New Brunswick were involved. The project was to create a scale model of the 58 -acre camp, its buildings, and the excavation for articles on the land that once was the internment camp. ${ }^{81}$ The internment camp museum is not on the same property as the original camp, but the artefacts within the museum building serve as a physical connection to the space of internment. Christine Whitehouse explores the creation of the museum and the interaction of young students with the historical site as a reconstructed the space of internment. ${ }^{82}$ The students were learning about their local history while also inserting the internee narrative into the public realm. The museum staff created a "Historical Trail" marking what remains of the original internment camp site. The walk takes about 15 minutes. Visitors are guided by signage along the trail that marks the original buildings, such as remnants from the old mess hall. ${ }^{83}$ Photographs posted on the website show the trail and signage along the path for the curious visitor. The descriptions serve as guides for exploring the space, much like Seidler's map, the National Post article, and the maps in the Ex-Internees Newsletter. While these signs and camp remains are physical markers of a space and allow to the visitor to envision the history much more easily, the guides Kallmann and I

\footnotetext{
81 "About the Museum," NB Internment Camp Museum, 2010, http://www.nbinternmentcampmuseum.ca/. 82 Whitehouse, "'You'll Get Used to It!'," 104-105.

83 "Visit our Historical Trail," NB Internment Camp Museum, 2010, http://www.nbinternmentcampmuseum.ca/.
} 
used demonstrate just some of the markers that can represent a physical space, while existing outside of that space.

Just as the museum, the National Post article and the map of Camp L were rooted in specific places. As the Ex-internees Newsletter and the post-internment community were not rooted in any specific physical space the discourse moved fluidly and beyond the geographical limits. The newsletter serves a virtual space in which the internees could explore the ways in which they were connected to multiple histories more freely. Kallmann discusses his trips to Germany and throughout multiple newsletters carries a conversation about the ex-internees' connection and the role the country may have served in their identity. Reunions for those ex-internees who arrived to England initially through the Kindertransport were advertised in multiple newsletters, Kallmann himself attending one. The ex-internees were also able to insert themselves into the discussion on various publications about internment and the Holocaust, the Australian Enemy Aliens and physical spaces such as the New Brunswick internment camp.

Whereas the New Brunswick internment camp in Canada fits securely in Canadian history, the Ex-Internees Newsletter as a private space allowed the internees to consider their connection to multiple places and histories. Thus, an initiative like the recent online exhibition Enemy Aliens, created by the Vancouver Holocaust Education Centre is a space in which the Jewish refugees' history of internment is inserted into a new space of discourse. The website is an educational tool for students and educators exploring the history of the internment of Jewish refugees. Throughout the exhibit in 
various dossiers are ex-internee interviews, photographs, and artefacts, acting similar to Koch's scrapbook: a medley of memories. There are lessons for students and teacher's guides available in each dossier, with various sections on education, religion, politics and morale in the camps. The exhibit states:

Many of the former internees went on to positions of prominence in academia, business and the arts. Among them are Members of the Order of Canada and two Nobel Laureates. The remarkable achievements of the interned refugees belied the arguments of the government officials who opposed their settlement in Canada. Their contributions highlight the lost potential of the fragment of European Jewry that Canada might have saved during the Holocaust. ${ }^{84}$

The importance of accomplishments in the post-internment community continues to be a recurring theme carried through in the various spaces of discourse concerning postinternment identity. The website gives a space for the internee voices to shine through, to demonstrate the impact the internees had on Canada and push them into a larger narrative of Canadian history. The internees put much importance on understanding their place in Canadian history, their triumphs, and their contributions to Canada. The Enemy Aliens exhibit is an extension of this ongoing conversation and virtual space for a community of internees who never had one geographical grounding.

In the beginning of each chapter in her PhD dissertation, Christine Whitehouse outlines the development of the postwar narrative of Jewish internment. She begins with interviews by CBC report Harry Rasky and concludes with the digital exhibition

\footnotetext{
84 "Achievements," Enemy Aliens: The Internment of Jewish Refugees in Canada, 1940-43, 2012, http://enemyaliens.ca/une_nouvelle_vie-new_lives/accomplissements-achievements-eng.html.
} 
Enemy Aliens. ${ }^{85}$ She argues that the Jewish refugees' identities were not made behind the barbed wire, but "made and remade through the memorialization of that past in the shadow of new and evolving presents." ${ }^{86}$ She later discusses the development of the memory archive of Jewish internment as,

created by former internees reaching out to camp friends through word of mouth, leaving out the "assorted characters'" stories. What emerged naturally as part of the process of collecting memories from known acquaintances in the late 1970s and early 1980s developed into a more deliberate pursuit in the 1990s when the impetus to get their legacy "right" increased as the former internees aged. ${ }^{87}$

This archive and community may have developed through word of mouth and those smaller internment networks shown through the data Koch collected. However, as we saw in Chapter Two, by the late 1970s and 80 s there already was a much larger social network. Indeed, that careful mapping of individuals and social connections makes clear just how developed and interconnected the internment community was long before the first Ex-Internees Newsletter was published. This is not to dispute the fact that Koch's information was gathered from word of mouth, but to demonstrate the power in approaching historical work from a different perspective. I argue the development of this "memory archive" of Jewish internment, in the lead up to and into the 1990s, represented more of an ongoing conversation in a searching for meaning rather than a reaction to the "shadows" of the evolving present. The ways in which this discourse took place was presented in different forms (artwork, letters, and newsletters) throughout

\footnotetext{
${ }^{85}$ Whitehouse, "'You'll Get Used to It!'," 19.

${ }^{86}$ Whitehouse, "'You'll Get Used to It!'," 20.

${ }^{87}$ Whitehouse, "'You'll Get Used to It!'," 81.
} 
the years. However, the post-internment connections and desire for community existed long before a recognizable space for this community to exist came to fruition.

The Ex-Internees Newsletter, while focussing on the accomplishments and successes, allows the internment narrative to develop into a conversation of the exinternees individual and collective worth as active contributors to Canadian society. Unlike Koch, Kallmann searches to define this community of ex-internees outside the camp boundaries, beyond the barbed wire. These newsletters point to the gendered nature of memory. The visual materials published in the newsletters point to a neatly defined set of internment camps where productive and professional men spent years. The artwork presented here is different from the artwork created during the time of internment. This speaks to Kallmann's embarrassment at the difference in his impressions of internment. The way in which he experienced and felt about Canada would be very different from the way he felt about Canada decades later. Similarly, the way internment is presented from the artefacts created at the time of internment to the discourse on internment years later demonstrates the complex nature of memory making and remembering.

This chapter has explored how the ex-internees interacted with their past in an attempt to understand and memorialize a history that was not bound in place. These actions throughout the decades became sites of memory: a space where discourse between ex-internees occurred. The Ex-Internees Newsletter became a place for this post-internment community to exist. Through the active efforts of planting their 
narrative in various spaces of discourse they were creating a virtual space for their history to be discussed and to interact with their ever-changing present. 


\section{Conclusion}

In the ex-internees' memoirs, artwork, diaries, and published newsletters there is a consistent longing for meaning and identity. The meaning they sought is expressed in various media throughout the decades post-internment. There was a consistent and widespread desire to be considered for their achievements beyond the internment camp. However, this thesis explores the period of time during their internment where internees created and circulated artwork, in addition to considering the significance of conserving the artwork during the post-internment years. As the ex-internees inserted their stories into paintings, archives, and newsletters throughout the years, they were contributing to a wider discussion on memory and history.

I chose three very different examples of memory and community to demonstrate the internees' evolving collective search for meaning. Each chapter dealt with a different methodology, time period, and way of thinking about memory. My analysis of community complicates the internment narrative. It looked to internment artwork, letter writing between ex-internees and post-internment newsletters, while using different methodologies and digital tools to visualize the presence of community and the function of networks in the post-internment era. The three lenses from which to evaluate the internee experience provide a fuller understanding of how the internees at the focus of my study remembered their experience and memorialize their history.

In Chapter One, the relationship between the internment community and the internee artwork revealed how community developed during the internment process. 
Communal activities such as education served as effective methods for challenging the monotony of camp life. Many internees found that education gave them back some independence and satisfied their thirst for knowledge. ${ }^{1}$ In this way, education challenged the wearying nature of camp life and served as the internees' own form of resistance. Artwork often became part of these organized programs, inadvertently forging community, while allowing individual internees to express their anguish through creativity. The paintings illuminate the complexities of masculinity and (hetero)sexuality during internment. However, as we saw in Chapter Three, in their post-interment preservation they also demonstrate a larger project of remembering.

Chapter Two built off of the importance of community established in the first chapter and discussed the use of digital tools to illustrate the post-internment community in a way that had not been done in previous scholarly work on Jewish internees. By visualizing the ex-internee network, it created space for new questions and discussions relating to the structure of these communities. The post-internment community points to a connection steeped in a shared sense of community and cultivated through memory. The importance of weaker ties or bridges between subcommunities provided insight into the role ex-internees played in the larger network, regardless of the overall strength of their connections. The weak ties demonstrate the power of the simplest connections between members of a network. While the internees may not have thought their few connections from camp to be important, their efforts to maintain the network prove fruitful. While using digital tools

\footnotetext{
${ }^{1}$ Martin F. Auger, Prisoners of the Home Front (Vancouver: UBC Press, 2009), 146.
} 
does not necessarily answer more questions, it opens avenues for posing different questions.

The final chapter examined the Ex-Internee Newsletter compiled by Helmut Kallmann. The newsletter is a result of a conversation concerning the human search for meaning and a conversation regarding the ex-internees' identity and legacy. It became a lieu de memoire and a virtual space for the community to exist. These examples highlight various ways in which sites of memory are created and maintained. They allow historians to carefully explore their own role in the creation of memory and history and their impact. Having visualized the post-internment community of the late 1970 s and 80 s while Koch was compiling information for his book, it becomes easier to imagine the post-internment community of the "Kallmann Era." Knowing there is a strong network already formed, it is easier to understand how this newsletter became so popular, so quickly among internees.

The social network visualization performed in Chapter Two adds depth to the historical study of Jewish internees in Canada and broadens the scope of my research. Knowing the presence of an ex-internee network allows the historian to view the archives differently. We should not merely see Eric Koch's fonds as a space that holds historical information sent to him for his memoir. Rather, we can and ought to appreciate it as an active and mobile space comprised of hundreds of voices and artifacts connected to a larger social network of memory. Similarly, while observing the artifacts, photographs, and interviews on the Vancouver Holocaust Education Centre's Enemy Aliens website historians should understand them not as standalone pieces to 
the internment story, but as pieces that also contribute to an already complex and strong social network of remembering and identification. ${ }^{2}$

While contributing to the historiography of Jewish internment in Canada, this thesis breaks from the traditional method of analysis. The works of historian Paula Jean Draper were foundational in contextualizing my understanding of the story of these 2,000 Jewish refugees. ${ }^{3}$ More broadly, this thesis interacts with studies on internment and displacement and the role of visual culture in the re-placement of abandoned spaces. ${ }^{4}$ This thesis is in part a conversation with Christine Whitehouse's recent work on the Jewish internment as it speaks to the developing nature of the internment narrative. When discussing the legacy of the internment experience, Christine Whitehouse situates this history as a case study in the discriminatory processes of democracy and nationbuilding. ${ }^{5}$ She argues that the collective memory of internment has changed throughout the decades to correspond to the contemporary political contexts. ${ }^{6}$ I argue that the collective memory and identity of these ex-internees speaks much more broadly to the

\footnotetext{
2 "'Enemy Aliens': The Internment of Jewish Refugees in Canada, 1940-43." Online Exhibit. http://www.enemyaliens.ca/.

${ }^{3}$ Paula Jean Draper, "The Accidental Immigrants: Canada and the Interned Refugees, Part I," Canadian Jewish Historical Society Journal 2, no. 1(Spring 1978): 1-38; Paula Jean Draper, "The Accidental Immigrants: Canada and the Interned Refugees, Part II," Canadian Jewish Historical Society Journal 2, no. 2 (Fall 1978): 80-112; Paula Jean Draper, "The Accidental Immigrants: Canada and the Interned Refugees" (PhD diss., University of Toronto, 1983). For other histories of Jewish internment see also: Martin F. Auger, Prisoners of the Home Front (Vancouver: UBC Press, 2009); Franca lacovetta, Angelo Principe, and Roberto Perin, eds., Enemies within: Italian and other internees in Canada and abroad (Toronto: University of Toronto Press, 2000); Ted Jones, Both Sides of the Wire, Vols. 1 \& 2 (New Brunswick: New Ireland Press, 1989); Ernest Robert Zimmerman, The Little Third Reich on Lake Superior, eds. Michel S. Beaulieu and David K. Ratz (Alberta: The University of Alberta Press, 2015). Christine Whitehouse, "You'll Get Used to It!' The Internment of Jewish Refugees in Canada, 1940-1943" (PhD diss., Carleton University, 2016).

${ }^{4}$ Kirsten McAllister, "Photographs of a Japanese Canadian internment camp, Visual Studies 21, no. 2 (October 2006): 133-156; Pamela Sugiman, "Passing Time, Moving Memories," Social History 37, no. 73 (2004): 51-79.

${ }^{5}$ Whitehouse, "'You'll Get Used to It!'," 179.

${ }^{6}$ Whitehouse, "'You'll Get Used to It!'," 179.
} 
ways in which memory is molded, gendered, and performed in varying situations. It is by looking to the discourse surrounding community and identity and through the use of various methodological avenues, that historians grasp complexity of the form and function of community. By gathering these pieces of memory, this thesis contributes to the wide body of literature on internment and provides unique interpretations of the community and its surrounding discourse.

This thesis is in large part a response to the voices of ex-internees, like Helmut Kallmann, who called for a narrative of their community that represented them beyond the internment history. The colossal display of accomplishments in the archives speaks to this longing to be known for more than their roles as once "enemy aliens." I began by grounding my analysis within the context of internment (Chapter One). I then uprooted it and transported it to for virtual display (Chapter Two). Following this, I explored a tangible expression of the post-internment community (Chapter Three). In doing so, I was able to evaluate the various factors that contribute to these various forms of the post-internment community.

This study on memory and identity building encourages historians to approach their work from new perspectives. This thesis demonstrates the value of digital humanities when encountering the archives and the sources within form an alternative angle. It becomes not only a question of what the sources convey, but how the historian integrates different methodologies to consider this complex history. The visualization of the post-internment community illustrated the intricate network of relationships, archival materials, and stories of internment. Considering the function and presence of 
the post-internment network challenges our understanding of this history and the ways in which memory building occurred. The power of the ex-internee letter becomes more than a conversation between two people, it conveys a larger discourse on identity and belonging within the internment narrative.

By maintaining connections with each other in their post-internment years, the ex-internees highlighted identify community as a key sinew to their past. This thesis has demonstrated the power of community and how integral it is to the history of these Jewish refugees. It has added to understandings of virtual spaces of memory and history. This thesis not only explored the history and memory of internment but also how the ex-internees' yearning for meaning illuminates larger questions about memory of histories that no longer have specific geographical roots. Because the postinternment community was not rooted in place, it was able to transcend the geographical boundaries of common memorials rooted in place and be inserted into multiple narratives. This demonstrates the ways in which a community can exist and be remembered in virtual space. Almost six decades later, these words written in anguish over their internment in Canada still ring true:

We are always together wherever we are wherever we gather we are what we are.

That gives us courage and clarity force hope and unity.

You are one of us we are everywhere where the world goes round everywhere whether free or bound. 
You are with us

and we with you.

We are today and tomorrow too

all of us - we and you. 


\section{Bibliography}

\section{Primary Sources}

Friedlander, Henry and Sybil Milton, eds. Archives of the Holocaust: An International Collection of Selected Documents. Volume 15. New York and London: Garland Publishing, 1991.

\section{Interviews}

Brown, Harry. "Eric Koch on being a German Jewish internee in Canada in 1940." Canada: Take 30. November 14, 1980. Television. 12:32. http://www.cbc.ca/archives/entry/eric-koch-on-being-a-german-jewishinternee-in-1940.

\section{Archival Materials}

\section{Library and Archives Canada}

Koch, Eric fonds. MG 30 C-192. Vols 1-3. Library and Archives Canada. Ottawa, Canada. Warschaur, Heinz. Heinz Warschaur's personal correspondence 1932-1978. MG 31 D129. Vol. 1. Library and Archives Canada. Ottawa, Canada.

Ottawa Jewish Archives

Reiche, Hans fonds. Ottawa Jewish Archives. Ottawa, Canada.

\section{Exhibits}

New Brunswick Internment Camp Museum. Online Exhibit. http://nbinternmentmuseum.com/.

"'Enemy Aliens': The Internment of Jewish Refugees in Canada, 1940-43." Online Exhibit. http://www.enemyaliens.ca/.

Helman, Susannah. The Dunera Boys: Seventy Years On. Canberra, Australia: National Library of Australia, February 2010. https://www.nla.gov.au/media-releases/thedunera-boys-seventy-years-on.

\section{Memoirs}

Bader, Alfred. Adventures of a Chemist Collector. London: Weidenfeld \& Nicholson, 1995. 
Igersheimer, Walter W. Blatant Injustice: The Story of a Jewish Refugee from Nazi Germany Imprisoned in Britain and Canada during World War II. Montreal \& Kingston: McGill-Queen's University Press, 2005.

Koch, Eric. Deemed Suspect: A Wartime Blunder. Toronto: Metheun, 1980.

Schild, Erwin. The Very Narrow Bridge: A Memoir of an Uncertain Passage. Canada: Adath Israel Congregation and Malcolm Lester, 2001.

\section{Newspapers}

Hamilton, Graeme. "How Jewish 'enemy aliens' overcame a 'traumatic' stint Hamilton, Graeme. "How Jewish 'enemy aliens' overcame a 'traumatic' stint in Canadian prison camps during the Second World War," National Post, February 7, 2014.

\section{Documentaries}

Oberlander, Wendy. Nothing to be Written Here. Canada, 1996. VHS.

\section{Digital Resources}

“Gephi: The Open Graph Viz Platform," version 0.9.1, http://gephi.github.io/.

Open Refine "Open Refine: A free, open source, powerful tool for working with messy data," http://openrefine.org/.

\section{Secondary Sources}

Atia, Nadia and Jeremy Davies. "Nostalgia and the shapes of history." Memory Studies 3, no. 3 (2010): 181-186.

Auger, Martin F. Prisoners of the Home Front: German POWs and "Enemy Aliens" in Southern Quebec, 1940-46. Vancouver: UBC Press, 2009.

Baader, Benjamin Maria, Sharon Gillerman, and Paul Lerner. "Introduction." In Jewish Masculinities: German Jews, Gender, and History. Edited by Benjamin Maria Baader, Sharon Gillerman, and Paul Lerner, 1-22. Bloomington \& Indianapolis: Indiana University Press.

Barabasi, Albert-Laszlo. Linked: How Everything Is Connected to Everything Else and What It Means for Business, Science, and Everyday Life. New York: Basic Books, 2014. 
Beckwith, John and Robin Elliott, eds. Mapping Canada's Music: Selected Writings of Helmut Kallmann. Waterloo: Waterloo University Press, 2013.

Bender, Thomas. Community and Social Change in America. New Brunswick, NJ: Rutgers University Press, 1978.

Boyarin, Daniel and Jonathan. "Diaspora: Generation and the Ground of Jewish Identity." Critical Inquiry 19.4(1993): 693-725.

Boym, Svetlana. The Future of Nostalgia. New York: Basic Books, 2001.

Boissevain, Jeremy. "Network Analysis: A reappraisal." Current Anthropology 20, no. 2 (June 1979): 392-394.

Bruggeman, Jeroen. Social Networks: An Introduction. Routledge, New York: 2008.

Buszek, Maria Elena. Pin-Up Grrrls: Feminism, Sexuality, Popular Culture. Durham and London: Duke University Press, 2006.

Carr, Gillian and H. C. Mytum. Cultural Heritage and Prisoners of War: Creativity Behind Barbed Wire. New York: Routledge, 2012.

Clifford, James. "Diasporas." Cultural Anthropology 9, no. 3 (Aug. 1994): 302-344.

Cohen, Robin. Global Diasporas: An Introduction. New York: Routledge, 2008.

Cresswell, Yvonne M. Living with the Wire: Civilian Internment in the Isle of Man During Two Cold Wars. United Kingdom: Manx National Heritage, 1994.

de Certeau, Michel. The Practice of Everyday Life. Berkeley: University of California Press, 1984.

Dempsey, Hugh A. "A Century of Alberta Political Cartoons." Alberta History 53, no. 2 (2008): 2-3.

Draper, Paula Jean. "The Accidental Immigrants: Canada and the Interned Refugees, Part I." Canadian Jewish Historical Society Journal 2, no. 1 (Spring 1978): 1-38.

----- "The Accidental Immigrants: Canada and the Interned Refugees, Part II." Canadian Jewish Historical Society Journal 2, no. 2 (Fall 1978): 80-112.

----- "The Accidental Immigrants: Canada and the Interned Refugees." PhD dissertation. University of Toronto, 1983. 
----- "The 'Camp Boy's: Interned Refugees from Nazism." In Enemies Within: Italian and other internees in Canada and abroad. Edited by Franca lacovetta, Angelo Principe, and Robert Perin, 171-193. Toronto: University of Toronto Press, 2000.

Duering, Martin. "Cheat Sheet: Social Network Analysis for Humanists." Digital Humanities LAB at CVCE powered by uni.lu. April 13, 2015. http://cvcedhlab.hypotheses.org/106.

"The dynamics of helping behavior for Jewish fugitives during World War II: The importance of brokerage. The Segal Family's Case." Online Encyclopedia of Mass Violence. March 29, 2016. http://www.sciencespo.fr/mass-violence-warmassacre-resistance/en/document/dynamics-helping-behaviour-jewishfugitives-during-second-world-war-importance-brokerage-se.

Farges, Patrick. "Masculinity and Confinement: German-Speaking Refugees in Canadian Internment Camps (1940-1943)." Culture, Society \& Masculinities 4, no. 1 (2012): 33-47.

Freud, Sigmund. "Fetishism," in The Standard Edition of the Complete Psychological Works of Sigmund Freud: The Future of an Illusion Vol. 21. Edited by James Strachey, 147-158. London: Hogarth Press, 1971.

Gerson, Judith. "Family Matters: German Jewish Masculinities among Nazi Era Refugees." In Jewish Masculinites: German Jews, Gender, and History. Edited by Benjamin Maria Baader, Sharon Gillerman, and Paul Lerner, 210-232. Bloomington \& Indianapolis: Indiana University Press.

Gilman, Sander. "Is Life Beautiful? Can the Shoah Be Funny? Some Thoughts on Recent and Older Films." Critical Inquiry 26, no. 2 (Winter 2000): 279-308.

Gilman, Sander. Jewish Frontiers: Essays on Bodies, History, and Identities. New York: Palgrave Macmillan, 2004.

Gilman, Sander. The Jew's Body. New York: Routledge, 1991.

Granovetter, Mark S. "The Strength of Weak Ties." American Journal of Sociology 78, no. 6 (May 1973): 1360-1380.

Hirsch, Marianne and Leo Spitzer. "'There Was Never a Camp Here': Searching for Vapniarka." In Locating Memory: Photographic Acts. Edited by Annette Kuhn and Kirsten Emiko McAllister, 135-154. New York: Berghahn Books, 2006. 138. 
lacovetta, Franca, Angelo Principe, and Robert Perin, eds. Enemies within: Italian and other internees in Canada and abroad. Toronto: University of Toronto Press, 2000.

Jones, Amelia. Seeing Differently: A history and theory of identification and the visual arts. New York: Routledge, 2012.

Jones, Ted. Both Sides of the Wire. Vols. 1 \& 2. New Brunswick: New Ireland Press, 1989.

Keane, David. "Cartoon Violence and Freedom of Expression." Human Rights Quarterly 30 (2008): 845-875.

Kobrin, Rebecca. "Rewriting the Diaspora: Images of Eastern Europe in the Bialystok Landsmanshaft Press, 1921-45." Jewish Social Studies 12, no. 3 (Spring/Summer 2006): 1-38.

----- Jewish Bialystok and Its Diaspora. Indiana: Indiana University Press, 2010.

Krieger, Nina and Paula Draper. “'Enemy Aliens': The Internment of Jewish Refugees in Canada, 1940-1943." Teacher's Guide.

Kwiet, Konrad. "'Be patient and reasonable!' The internment of German-Jewish refugees in Australia." Australian Journal of Politics \& History 31, no. 1 (April 1985): 61-77.

Langfield, Michele. "'Lost Worlds': Reflections on Home and Belonging in Jewish Holocaust Survivor Testimonies." Jewish Culture and History 9, no. 2-3 (May 2012): 33-48.

Lipman, Steve. Laughter in Hell: The Use of Humor during the Holocaust. Northvale, NJ: J. Aronson Inc., 1991.

McAllister, Kirsten Emiko. "Archive and Myth: The Changing Memoryscape of Japanese Canadian Internment Camp." In Placing Memory and Remembering Place in Canada. Edited by James Opp and John C. Walsh, 215-243. Vancouver: UBC Press, 2010.

McAllister, Kirsten. "Photographs of a Japanese Canadian internment camp." Visual Studies 21, no. 2 (October 2006): 133-156.

McMillan, Barclay and Elaine Keillor. "Helmut Kalmann." The Canadian Encyclopedia. December 2, 2012. http://www.thecanadianencyclopedia.ca/en/article/helmutkallmann/. 
Mulvey, Laura. "Visual Pleasure and Narrative Cinema." In Film Theory and Criticism: Introductory Readings. Edited by Leo Braudy and Marshall Cohen, 833-44. New York: Oxford University Press, 1999.

Netz, Reviel. Barbed Wire: An Ecology of Modernity. Connecticut: Wesleyan University Press, 2004.

Nora, Pierre. "Between Memory and History: Les Lieux de Memoire." Representations 26 (Spring 1989): 7-24.

Opp, James \& John C. Walsh, eds. Placing Memory and Remembering Place in Canada. Vancouver: UBC Press, 2010.

Ostrower, Chaya. "Humor as a Defense Mechanism during the Holocaust." Interpretation: A Journal of Bible and Theology 69 no. 2 (2015): 183-195.

----- It Kept Us Alive: Humor in the Holocaust. Translated by Sandy Bloom. Jerusalem: Yad Vashem, 2014.

Read, Peter. “Leaving Home.” Journal of Australian Studies 23, no. 61 (1999): 35-46.

Rosenberg, Pnina. "Mickey Mouse in Gurs - Humour, Irony and Criticism in Works of Art Produced in the Gurs Internment Camp." Rethinking History 6, no. 3 (2002): 273292.

Safran, William. "Diasporas in Modern Societies: Myths of Homeland and Return." 1, no. 1 (Spring 1991): 83-99.

Saunders, Kay and Helen Taylor. "The Enemy Within? The Process of Interning Enemy Aliens in Queensland 1939-45." Australian Journal of Politics \& History 34, no. 1 (April 1988): 16-17.

Sugiman, Pamela. "Passing Time, Moving Memories: Interpreting Wartime Narratives of Japanese Canadian Women." In Rethinking Canada: The Promise of Women's History, 6th ed. Edited by Mona Gleason, Tamara Myers, and Adele Perry, 262282. Toronto: Oxford University Press, 2011.

Unknown. "Tutorial Layouts." Gephi: The Open Graph Viz Platform. https://gephi.org/users/tutorial-layouts/.

Vance, Jonathan F. Encyclopedia of Prisoners of War and Internment. Santa Barbara: ABC-CLIO, 2000. 
Vischer, A. L. Barbed Wire Disease: A Psychological Study of the Prisoners of War. London: John Bale, Sons, and Danielsson, 1919.

Walsh, John C. "Performing Public Memory and Re-Placing Home in the Ottawa Valley, 1900-58." In Placing Memory and Remembering Place in Canada. Edited by James Opp and John C. Walsh, 25-56. Vancouver: UBC Press, 2010.

Walsh, John C., and Steven High. "Re-thinking the Concept of Community." Histoire Sociale/Social History 32, no. 64 (1999): 255-273.

Weber, Max and Talcott Parsons. The Theory of Social and Economic Organization. New York: Free Press, 1947.

Weingart, Scott B. "Demystifying Networks, Parts I \& II." Journal of Digital Humanities 1, no. 1 (Winter 2011). http://journalofdigitalhumanities.org/1-1/demystifyingnetworks-by-scott-weingart/.

Whitehouse, Christine. "'You'll Get Used to It!': The Internment of Jewish Refugees in Canada 1940-1943." PhD dissertation. Carleton University, 2016.

Zimmerman, Ernest Robert. The Little Third Reich on Lake Superior. Edited by Michel S. Beaulieu and David K. Ratz. Alberta: The University of Alberta Press, 2015.

Zweig, Katharina A. Network Analysis Literacy: A Practical Approach to the Analysis of Networks. Austria: Springer, 2016. 